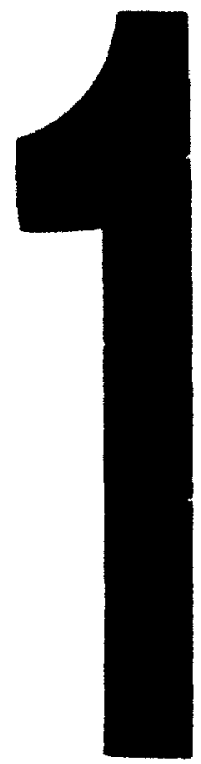

PM-1 3' 2 "X4" PHOTOGRAPHC MICAOCOPY TARGET NBS 1010a ANSI/1SO "2 EQUIVALENT

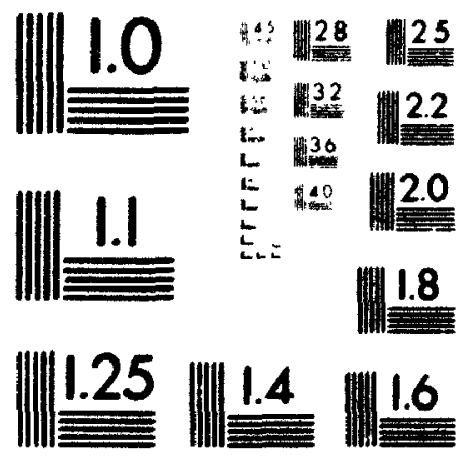


The quality of this microform is heavily dependent upon the quality of the original thesis submitted for microfilming. Every effort has been made to ensure the highest quality of reproduction possible.

If pages are missing, contact the university which granted the degree.

Some pages may have indistinct print especially if the original pages were typed with a poor typewriter ribbon or if the university sent us an inferior photocopy.

Reproduction in full or in part of this microform is governed by the Canadian Copyright Act, R.S.C. 1970, c. C-30, and subsequent amendments.
La qualité de cette microforme dépend grandement de la qualité de la thèse soumise au microfilmage. Nous avons tout fait pour assurer une qualité supérieure de reproduction.

S'il manque des pages, veuillez communiquer avec l'université qui a conféré le grade.

La qualité d'impression de certaines pages peut laisser à désirer, surtout si les pages originales ont été dactylographiées à l'aide d'un ruban usé ou si l'université nous a fait parvenir une photocopie de qualité inférieure.

La reproduction, mime partielle, de cette microforme est soumise à la Loi canadienne sur le droit d'auteur, SRC 1970, c. C-30, et ses amendements subséquents. 
The Environmental Crisis in st. Petersburg: An Analysis of Its Roots, Current status, and Future Prospects

$$
\text { by }
$$

Kerry Franchuk

A thesis submitted to the Faculty of Graduate Studies in partial. fulfillment of the requirements for the degree of Master of Arts

Institute of Central/East European and Russian Area Studies

Carleton University

Ottawa, Canada 
The author has granted an irrevocable non-exclusive licence allowing the National Library of Canada to reproduce, loan, distribute or sell copies of his/her thesis by any means and in any form or format, making this thesis available to interested persons.
L'auteur a accordé une licence irrévocable et non exclusive permettant à la Bibliothèque nationale du Canada de reproduire, prêter, distribuer ou vendre des copies de sa thèse de quelque manière et sous quelque forme que ce soit pour mettre des exemplaires de cette thèse à la disposition des personnes intéressées.

L'auteur conserve la propriété du droit d'auteur qui protège sa thèse. Ni la thèse ni des extraits substantiels de celle-ci ne doivent être imprimés ou autrement reproduits sans son autorisation.

ISBN $\quad 0-315-84140-0$ 
Frarchak

Dismer $K<r 1$ tention Aabstracts international is ai ranged by broad, general subject categories Please select the one subject which most netarly describes the content of your dissertation Enter the corresponding four digit code in the spoces provided.

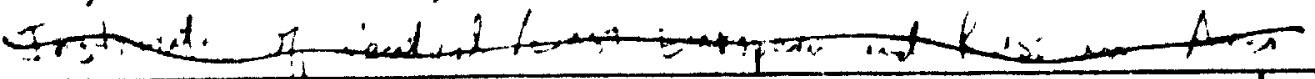

INTERNATTIONAT LAW SUBSET TERM

" sbject Categories
0,6116 U.M.I

SUBSECT CODE

\section{THE huMANITIES AND SOCIAL SCIENCES}

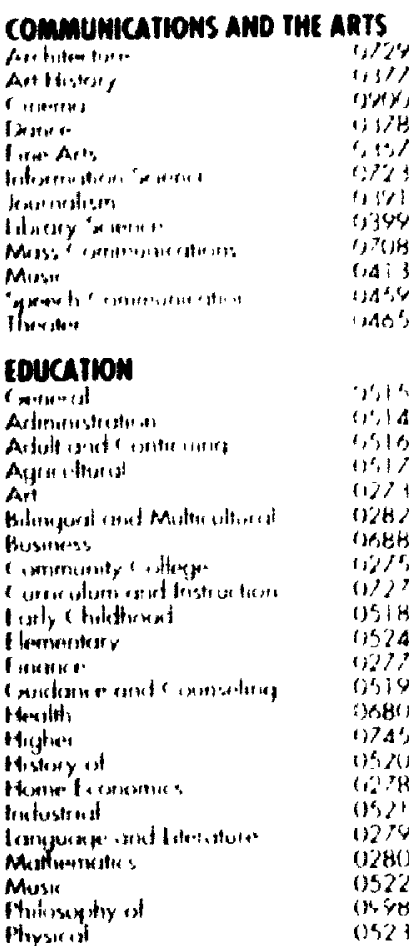

\section{PHILOSOPHY, RELIGION AND}

THEOLOGY

Philosophy

Peiligion

Beneraí

Cleigr

History of

Pnilosophy of

Theology

SOCBAL SCIENCES

American Studies

Anthropology

Aichoeology

Cultura!

Business Adrimnistration

General

Accounting

Banking

Manogement

Maiketing

Conodian Studies

Economics

General

Agricultural

Commerce Busmess

Finance

History

Lobor

theory

folklore

Geography

Gerontology

Hisiony
4422

0318

0321
0319

0320

0322
0469

0323

0324

0326

032

0310

0272
0770

0770

0338

0385

0501

0503

0505

0508

0510

0511

0358

0366

0351

0578
Ancient 0570

Medieval

Modern

Black

Aficon

Aficon

Asia Australia and Oceania 0332

Canodion

European

Lotin American

Middle Eastern

History of Sxience

Low

Genera!

internotiond low and

Relations

Public Administrotion

Recreation

Social Work

Sociology

Criminology and Penology

Demography

Ethric and Rocint Studies

individual and fomly

Studies

Industrial and Labor

Relations
Public and Social Weifare

Social Structure and

Development

Theory and Methods

Transportation

Urban and Regional Plonning

Women's Studies
0460

Speech Putholagy

Home Economics

\section{PHYSICAL SCIEAcES}

Pure Sciences

Chemistry

General

Agricultural

Buchemistry

Inorgar is

Nuclear

Orgonic

Pharmaceutical

Physisal

Radiation

Mathematics

Physics

Generd

Astronomy and

Astrophysics

Atriospheric Scterice

Alomic

Electionics and Electricit.

Elementary Parictes and

High Energy

Flud and Plasmo

Molexular

Nuclear

Ophics

Solid State

Stotistics

Applied Sciences

Applied Mechanics

Computer Scrence

0346
Engineering

Aesospoce

Agricultural

Automolive

Biomedical

Chemical

Civil

Electronies and Electrieal

Heat and Thermadynomics

Hydraulic

industria

Morine

Materials Science

Mexhanical

Metallurgy

Mining

Nuclear

Packoging

Petroieum

Sanitary and Munis pal

System Science

Geotechnology

Operations Research

Plastics Technology

Textile lechnology

\section{PSYCHOLCOY}

General

Clinical

Developmental

Experimentol

Industriaí

Personality

Physiological

Psychobiology

Psychoinetsics 
The undersigned recommend to the Faculty of Graduate Studies and Research acceptance of the thesis

"The Environmental Crisis in Sc. Petersburg: An Analysis of Its Roots, Current Status, and Future Prospects"

submitted by Kerry Franchuk, B.A., in partial fulfillment of the requirements for the degree of Master of Arts
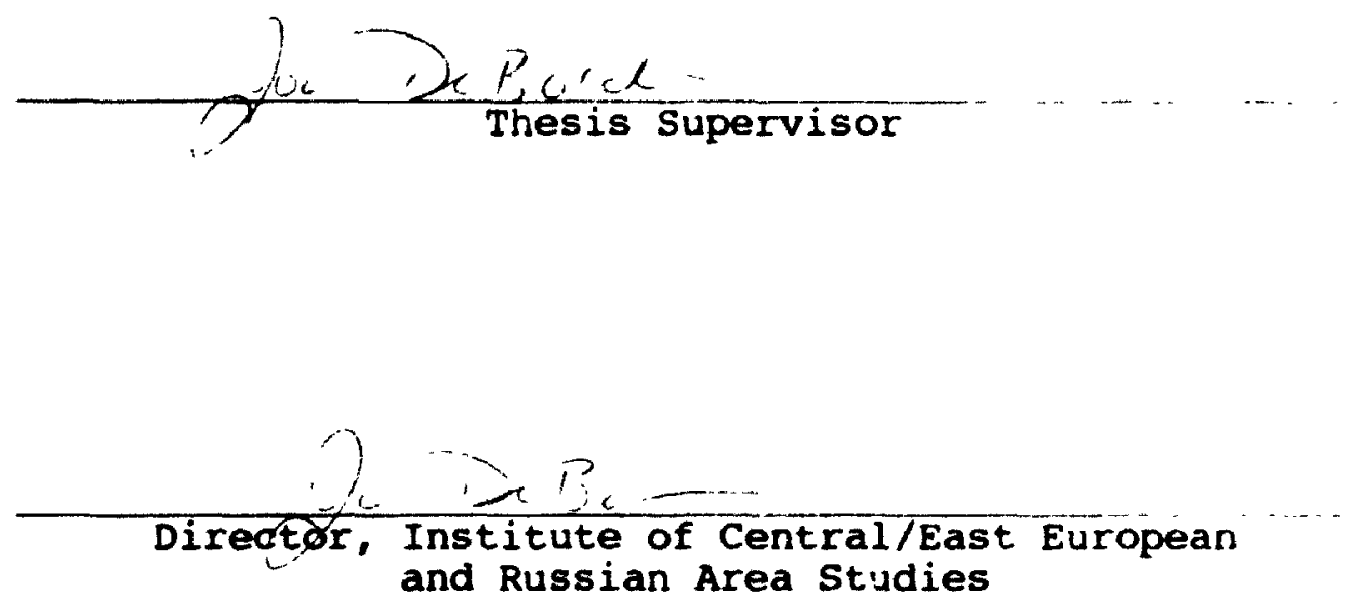

Carleton University

21 May 1993 


\section{TABLE OF CONTENTS}

TABLE OF CONTENTS $\ldots \ldots \ldots \ldots \ldots \ldots \ldots \ldots \ldots \ldots \ldots \ldots \ldots$

ACKNOWLEDGMENTS ...........................

NOTES ON TRANSLITERATION ...................... iv

ABSTRACT $\ldots \ldots \ldots \ldots \ldots \ldots \ldots \ldots \ldots \ldots \ldots \ldots \ldots \ldots \ldots \ldots \ldots \ldots$

Chapter I

INTRODUCTION $\ldots \ldots \ldots \ldots \ldots \ldots \ldots \ldots \ldots \ldots \ldots \ldots \ldots \ldots \ldots \ldots \ldots \ldots$

Chapter II

BACKGROUND TO ENVIRONMENTAL DISRUPTION IN THE SOVIET

UNION ......................................

The Geographical setting .................... 4

Philosophical setting ....................... 5

The Economic setting .......................

Central planning ........................ 8

The Pricing system ..................... 15

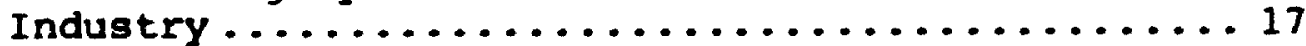

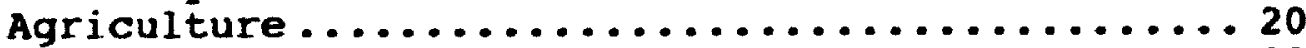

The Socio-Political setting ................... 23

Ecological Administration ................ 24

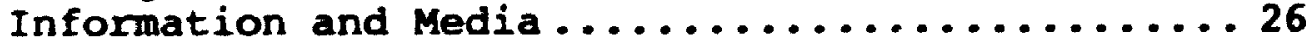

Education ............................ 30

The Environmental Movement ............... 32

Environmental Law .................... 35

Chapter III

LOCAL FACTORS IN ENVIRONMENTAL IISRUPTION OF ST.

PETERSBURG .................................41

The Geoyraphical setting ....................41

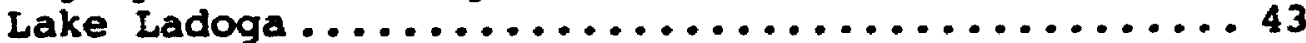

The Gulf of Finland .................... 49

The Air ............................. 62

The Economic setting ....................... 64

Industry ........................... 64

Agriculture ......................... 74

Energy, Transport, and waste Disposal ........ 77

The socio-Political setting .................. 84

Ecological Administration .................84

Information and Media ...................91

The Environmental Movement................. 92

Population Pressures .................... 98

Environmental Law ....................... 100

Chapter IV

ECOLOGICAL ANALYSIS AND FUTURE PROSPECTS ............. 102

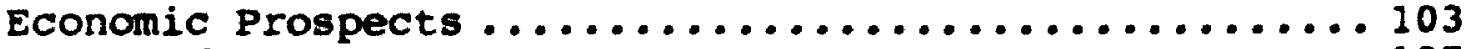

Industry .............................. 107 
Agriculture ........................... 114

Energy, Transport, and Waste Disposal ......... 114

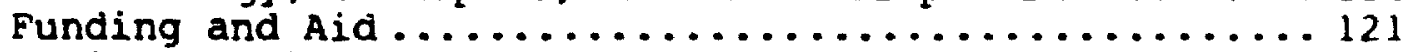

Socio-Political Prospects ................... 126

Ecological Administration ............... 127

Environmental Law ..................... 135

The Environmental Movement.............. 137

Natural Resources .......................... 142

Chapter $\mathrm{V}$

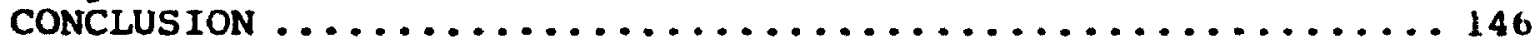

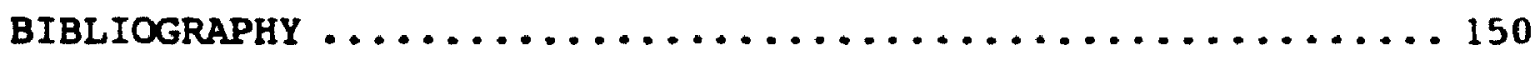

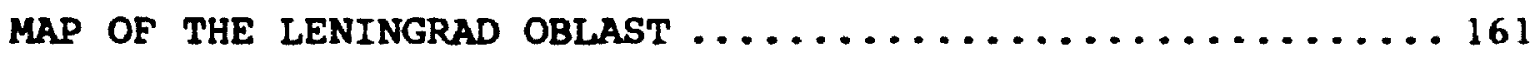

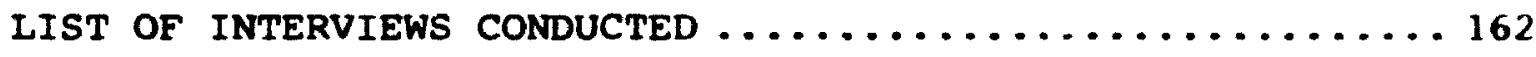




\section{ACKNOKLEDENRNTS}

I cannot possibly list here all the people who helped me, both directly and indirectly, to bring this paper to fruition. Nonetheless, I would particularly like to thank (in no particular order) my family and friends; Carleton International for the St. Petersburg exchange; my advisors in St. Petersburg, particularly Geral'd Shalabin; my advisor at Carleton, Joan DeBardeleben; Donna Harper; Cristina Warren; Nancy Humphrey; Carleton University; my professors at Carleton; and the myriad others-you know who you are. Thanks a bunch. 


\section{NOTES ON TRANSIITERATION}

With a few exceptions, I have used the Library of Congress system of transliteration, without diacritical marks, throughout this paper. Exceptions are, first, in the case of well-known Russian words, like Yeltsin or Lake Ladoga. I have used the commonly accepted form. Second, in cases where another source has already transliterated the word and I have not seen the original Russian spelling, I have retained the transliteration used by the source, no matter which system was employed. 


\section{ABSTRACT}

The roots of environmental disruption in the former Soviet Union are much different from those experienced in the capitalist West. These roots, together with local factors like the economic base and abundant water and forest resources, have defined the environmental character of Leningrad/St. Petersburg.

The Leningrad region currently finds itself in an ecological quagmire, with severe water pollution, soil contamination, problems with the nearby nuclear power station, and moderate air pollution. It is hoped that the economic and political changes taking place in the country and the area will serve to ameliorate the situation. However, conditions are so severe, and the current economy and political system so weak and chaotic, that near-term improvement in the state of the environment is impossible. Only in the long-term is melioration of the local ecological crisis possible. 


\section{INTRODUCTION}

Let us not... flatter ourselves overmuch on account of our human conquest over nature. For each such conquest takes its revenge on us.... Thus at every step we are reminded that we by no means rule over nature like a conqueror over a foreign people... but that we, with flesh, blood, and brain, belong to nature, and exist in its midst, and that all our mastery of it consists in the fact that we have the advantage over all other beings of being able to know and correctly apply its laws. 1

Given the world's experiences in the environmental

sphere in the years since Frederich Erigels wrote this passage in the 19th century, it would seem that there could be little debate over their wisdom. Environmental disruption has transcended all the earth's boundaries, be they economic, political, or geographic, and neither capitalists nor communists have been immune to it. As one of the co-founders of communism. Engels commanded much respect in traditional Soviet ${ }^{2}$ thinking, yet his words often went unheeded as the Soviets opted instead to conquer nature, to mold it to their

\footnotetext{
IFrederich Engels, Dialectics of Nature, trans, and ed. Clemens Dutt, (New York: International Publishers, 1940), pp. 291-92.

2The disintegration of the Soviet Union has, not surprisingly, given researchers and writers difficulties from many perspectives, ore of them being purely definitional; the changing of many of the nawes is somewhat confusing. I will be using the following names with the given definitions, but there are times when it is difficult to adhere to these strictly. First, I use the names "U.S.S.R." and "Soviet Union" interchangeably to define that geographic and political entity unt il its break-up in December 1991. When used with the word "former," these terms mean the territory or governments currently occupying the place of the Soviet Union. "Russia" is used to name the present area and government, with "R.S.F.S.R." being Soviet Rusgia. "Leningrad" defings the city from 1924 until the late sumer 1991, while "St. Petersburg" is the city since that time and before 1914. As of the summer of 1992, the oblast retained its name "Leningrad Oblast," hence many organizat sons in the area contain the name "Leningrad" in their titles.
} 
will, to force it to do their bidding, and to ignore it or abuse it when it was in their economic or short-term interest to do so. Soviet thinkers have justified Engels's words by claiming they pertain only to the plundering capitalists, or that they simply mean that one can dialectically foresee the consequences of intervention in nature, but that they by no means prohibit that intervention. 3 No matter the justification, ignoring the spirit of Engels's words has not been without its price.

Not unlike cities throughout the world, St. Petersburg is faced with ecological problems, and it shares with the world many of the basic causes for these problems. But there are many factors that are endemic solely to the former U.S.S.R. Under Soviet power, an economic system ill-equipped to handle the country's environmental needs and a closed political system were among the major factors that brought the country to its current ecological status. St. Petersburg's unique water and forest resources and its industrial development, to name just a few factors, have combined with the national elements to give the area its unique environmental character.

st. Petersburg suffered serious, long-term, deep-rooted, and widespread environmental degradation under soviet power. Through reforms in the economic and socio-political systems, there is hope to ameliorate the situation. But the outlook

\footnotetext{
${ }^{3}$ Douglas R. Weiner, Models of Nature: Ecology, Conservation, and Cultural Revrlution in Soviet Rusgia, (Bloomington and Indianapolis: Indiana University Press, 1988), p. 195.
} 
for positive change in the near-term in these areas is dismal, and the environment will continue to suffer as a result. Only in the long-term can the ecological problems of St. Petersburg be solved.

This paper wili focus on the root causes of the environmental disruption in Leningrad/St. Petersburg as it arose under Soviet power and on a historical examination of the problems that have led to the current er ironmental predicament of the city as of the sumner of 1992. Then, with the root causes and the problems themselves in mind, Chapter 4 will present an analysis of the current situation and future prospects for the area.

First, it necessary to gain some insight into the general causes for environmental disruption in the country itself: the problems of the region in question are, in large part, the product of the Soviet system and must be understood in this context. 


\section{BACKGROUND TO ENVIRONRENTAL DISRUPTION IN TER SOVIET UNION}

The ecological situation as it stands today in St. Petersburg arose from concrete national and local underpinnings; there are innumerable philosophical, economic, political, and geographical reasons that the environment has reached its present state. In this chapter, I will examine only those roots that are endemic to the U.S.S.R. as a whole and that had an effect on Leningrad/St. Petersburg.

\section{THE GEOGRAPEICAL SETTIMG}

Geographical factors regarding the Soviet Union cannot be overlooked in examining environmental deterioration. As will be explored later, the great size of the land mass has helped instill in its inhabitants the notion that, even as natural resources are devoured and land, air, and water are spoiled, there will always be more to replace what is lost or used up. There is a certain logic, not merely a mind-set, to the fact that resource-rich countries have less concern with conservation of natural resources. Not unlike Canada and the United States, the Soviet Union has paid the rrice for its abundance with a high resource consumption rate.1

With its abundance of fossil fuels, the Soviet Union tended to rely heavily on coal, oil, and wood in heating and

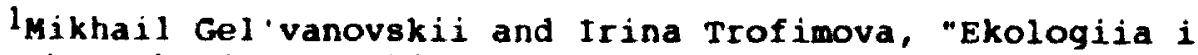
resursosberezhenie: nashi problemy i zarubezhnyi opyt," [Ecology and Resource Conservation: Our Problems and the Foreign Experience, ) Mrovala ekonomika $i$ mezhdunarodnye otnosheniia, 12 (1991), p. 131.
} 
industry. The burning of these fuels is a leading cause of air pollution. Moreover, the low grade of coal commonly employed in domestic electricity production produced great amounts of ash and sulfur.

Because of its location, the Soviet Union also was an importer of air pollution. At the 1988 Glasgow University Conference on Soviet Environment, Doctor victor L. Mote pointed out that, in addition to the nearly 12 million metric tons of sulfur oxides produced each year in the U.S.S.R., the country was receiving some 3 million tons from Europe.? Scientists estimate that 208 of the sulfur falling in the former U.S.S.R. comes from countries along the western border. In some border areas, 30-508 of local air pollution comes from foreign sources. ${ }^{3}$

\section{PAILOSOPHICAL ERTtig}

The Marxist-Leninist ideology that served as the philosophical foundation of the Soviet Union is the underlying raison d'être for much of the environmental disruption that took place in the country. One of the greatest culprits of pollution is, of course, the manufacturing sector. Production can wreak havoc on the air, land, and water used by industry, as experienced by capitalist and communist economies alike. Nonetheless,

\footnotetext{
${ }^{2}$ victor L. Mote, "A Summary of the Glasgow Conference on Soviet Environmental Policies and Practices," Soviet Geography, June 1988, p. 628 .

3D. J. Peterson, "The State of the Envirunment: An Overview," Report on the U.S.S.R., 23 February 1990, p. 19.
} 
special circumstances set soviet industry apart from its Western counterpart. In the U.S.S.R., industrialization was the primary concern in socialist development. From its very base in Marxist economics, Soviet Communism defined itself in terms of industrialization.

Political scientist Charles $E$. Ziegler traces the history of Marxist thought with regard to nature and society. contrasting the slavophile and Westernizing philosophies of the 19 th century in environmental terms. While the Slavophiles idolized Russian rural life, with its nonmaterialist socialism and innocence, the Westernizers took a utilitarian, materialistic approach to nature. Russian Marxism, according to $\mathrm{ziegler,} \mathrm{rejected} \mathrm{the} \mathrm{peasant} \mathrm{populism}$ of the Slavophiles, embracing instead the Westernizing, techno-centric position. Ziegler continues:

The Marxists materialist perspective embodied the historical determinist perception of economic yrowth as inherently progressive. In their view, technological development was the primary causal agent of social and political development; and agrarian society in which nature was not radically remolded to suit civilization's needs was by definition inferior to an industrial society.4

Lenin, in keeping with his Marxist ideological ancestry, held similar views. In a speech at the Eighth All-Russia Congress of Soviets in 1920, he espoused this theme. In describing the formula for overthrowing capitalism, Lenin claimed that the only way to undermine capitalism was "...to

\footnotetext{
${ }^{4}$ Charles E. Ziegler, Environmental Policy in the U.S.S.R., (London: Frances Pinter Publishers, 1987), pp. 6-8.
} 
place the economy of the country [Russia], including

agriculture, on a new technical basis, that of modern largescale production." He continued, "Communism is soviet power plus the electrification of the whole country."s Lenin did not make this generalization lightly: he considered industrialization to be at the very heart of communism. Industrialization took its place among the legitimizing factors for the existence of the soviet state, and as such remained sacrosanct, even throughout periodic leadership changes and economic reforms. Industrial build-up in a Marxist-Leninist society is contained a priori in the definition of Marxism-Leninism.

Just as important, perhaps, as the Marxist-Leninist base is the stalinist mode of thought that followed, for it was Stalin's system that essentially operated in the Soviet Union for nearly 60 years. Stalin embraced and implemented rapid industrialization, silenced criticism, stifled objective science, and implemented other policies wherein little attention was paid to the environmental consequences.

\section{TEE ECOHOMIC SETTIMG}

The Stalinist command economic system was a unique phenomenon in economics and that feature of the soviet economy that most distinguished it from capitalism. Despite periodic reformation attempts and the recent moves toward

\footnotetext{
5vladjmir Ilich Lenin, Sobranie sochinenii, (Collected Works, ] vol. 31, ed. Julius Katzer, (Moscow: Progress publishers, 1966), $p$. 516, emphasis in original.
} 
capitalism, in this economic system are embedded the deepest roots of environmental destruction.

\section{Central Planning}

In theory, the soviet model of central economic planning should have obviated pollution: there was nothing that was external to the planners objectives. Just as the planners could dictate the number of automobiles to be produced in a given year, they could plan for and regulate environmental quality. 6 In practice, unfortunately, the situation was very different.

In the Soviet system, the central planning system was divided into branches along functional lines, each run by a particular ministry, like Fertilizer production, Power and Electrification, or Transport Construction. The structure was such that each ministry attempted to establish and strengthen itself at any cost, so that interdepartmental rivalries, which inhibited adequate economic and environmental management, arose. This jealous and careful guarding of self-interest was known as departmentalism. The structure and the behavior it helped to spawn led to several problem areas.

"Because of their specialized focus," Carleton University's Joan DeBardeleben notes, "ministries and their organs fail to take into adequate account the effects of their activities on other sectors of the economy or on the

\footnotetext{
6Paul R. Gregory and Robert C. Stuart, Soviet Economic structure and Performance, (New York: Harper and Row, 1986), p. 376.
} 
environment."7 In pursuing their own interests, the departments ignored environmental costs, choosing instead to force another sector to deal with them. This departmentalism can be better understood by further dissecting the central planning system.

In the capitalist enterprise, managers can make decisions based on profit; when polluting begins to cost more because of fines, consumer backlash, etc., than taking precautions against it, the capitalist will stop polluting in order to maximize profits. In the Soviet system, however, there was no such clear measure for decision-making. The state planners, Gosplan, and, in turn, regional economic planners, dictated output and input levels to enterprise managers who were then bound to the dicta. The plan contained multiple targets, for example, outputs, cost. reductions, innovations, and environmental targets, as well as miltiple constraints. Therefore, the managers were faced with deciding which success indicators to follow. Since the planners placed the most emphasis on and tied the most rewards to gross output, or valovaia produktsiia, ti.e economic ministry and individual manager did likewise. AlI other targets not directly related to gross output then became secondary, including environmental plans as formulated

${ }^{7}$ Joan DeBardeleben, The Environment and Marxism-Leninism: The Soviet and East German Experience, (Boulder, Colorado: Westuiew rress, 1985), p. 219 . 
by the planning agencies. ${ }^{8}$ Thus was environmental planning forced into the background.

In choosing to follow gross output as their principal success indicator, managers were merely acting in accord with their ministry's wishes. Among incentives for factories were bonuses for workers and managers for fulfilling various assignments. Unfortunately, the bonuses were lopsided in favor of sheer production; fulfillment of the production plan would bring workers bonuses of $30 \%$, while fulfillment of environmental measures paid only $108.9^{9}$ Clearly, if the ministry itself put little stock in environmental measures, the managers and employees at the lower rungs of the economic ladder could not have been expected to do so.

Strict adherence to the plan had further detrimental effects. By striving to fulfill targets, managers tended to act in an economically irrational manner. Alec Nove remarks that one symptom of the gross output mentality was "output for the storeroom," that is, output of items that were not wanted by any buyer, and therefore merely ended up in storage. 10 Also, the form that the gross output dicta were liable to take varied, but usually focused on some quantitative aspect of production. For instance, if total output was to be measured in weight, the final products would

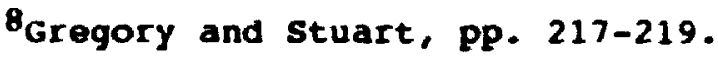

9Mote, "A Summary...., p. 627 .

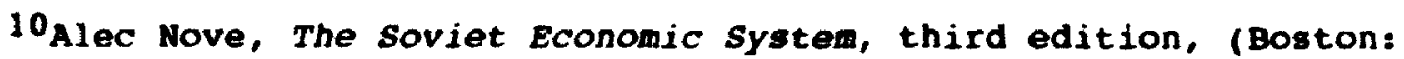
Allen and Unwin, Inc., 1986), p. 91.
} 
weigh more than necessary, while if the goal called only for the production of a numerical quota of items, quality and assortment would be ignored, and so forth. Moreover, enterprise managers and workers tended to work at breakneck speed near the final phase of a project in order to complete assigned tasks and thus earn bonuses. This practice, known as storming, often resulted in waste, inferior output, and neglect of environmental impact. ${ }^{11}$ From these corollaries of the valovaia produktsila phenomenon, the environmental consequences can be seen: energy and natural resources were wasted and, in turn, greater environmental disruption resulted in obtaining them; shoddy products like appliances and cars are greater energy consumers, emit more pollution, and break down sooner, requiring replacement and resulting in disposal problems; unwanted products had to be disposed of, stored, or recycled, all of which resulted in more environmental disruption; and incidents like the Chernobyl accident occurred in part because of the poor or defective technology employed.

Further problems arose from the economic structure. Environmental inspectorates were of ten contained within the very ministry responsible for running the enterprises and, subsequently, fulfilling economic plans. 12 In other words,

${ }^{11}$ Charles R. 2iegler, "The bear's View: Soviet Environwentalism," Technology Review, April 1987, p. 47.

12 Tatiana zaharchenko, personal interview, 12 January 1990, San Francisco, CA. 
the fox was appointed caretaker of the chickens. Such conflicts of interest can have disastrous effects. Ministries were known to downplay hazards, even going so far in some cases as to claim that factory emissions were actually beneficial to surrounding areas.13

The ministries often proved to be incapable of controlling environmental pollution, even when their intentions were sincere. They lacked the competence, specialists, and equipment for adequately patrolling themselves.14 Technical problems with outputs have already been mentioned, but these same outputs were not merely consumer goods like automobiles, but intermediate inputs, like pollution control equipment for enterprises. For example, the Christian Science Monitor reported in 1987 that filters produced in the West for coal power plants cut nitrogen-oxide emissions by 40 to 50 percent, while those of East Europe resulted in just 10 to 15 percent reduction.15 And treatment facilities at enterprises were often found to be poorly built and operated, with staff, in some cases, being expected to run operations for which they had not been

13 see Valentin Rasputin, "W3 Have Only One Baikal," Izvestiia, 17 February 1986: 3,6; Current Digest of the soviet Press, 7 (1986), p. 6 .

14 Boris Komarov, Unichtozhenie prirodys obostrenie ekologicheskogo krizisa v SSSR, [Destruction of Natures Intensification of the Ecological Crisis in the U.S.S.R.,l (Frankfurt: Possev-verlag, v. Corachek R. G., 1978), p. 102 .

15 william Echikson, "Hostile Neighbors Find Common Ground in Fighting Pollution," Christian Science Monitor, 18 November 1987, p. 8. 
properly trained. 16 part of the problem is that there were virtually no construction firms specializing in pollution control. This was left to general-purpose construction enterprises, operating under contract. 17

Specialists were also lacking. In 1979, Ekonomicheskaia gazeta commented that there was not a single institution in the whole country that trained specialists in solid waste processing, estimating that 5 thousand were needed at that time. 18 More recently, a vice-president in the Academy of Sciences stated that scientists cannot keep pace with the flood of requests for ecological studies, so the planning of big projects goes on without their input. 19 shortages of other skilled personnel were common.20

Another shortcoming concerns national accounting practices in the Soviet Union. Traditionally, pollutioncontrol expenditures were considered nonproductive

\footnotetext{
16 See John M. Kramer, "Environmental Problems," The Soviet Union Today, ed. James Cracraft, (Chicagos University of Chicago Press, distributor, 1983), p. 157, and Marshall I. Goldman, The Spoils of Progress: Environmental Pollution in the Soviet Union, (Cambridge, Massachusetts and London: H.I.T. Press, 19721, pp. 197-198.

17Thane Gustafson, Reform in Soviet Politics: Lessons of Recent Policies on Land and Water, (Cambridge, Massachusetts; New York; and Melbourne: Cambridge University Press, 1981), p. 117.

18v. Raznoshchik and V. Lobov, "Attack on Solid Waste," Ekonomicheskaia gazeta, 3 (1979): 16: Current Digest of the soviet Press, 4 (1979), p. 15.

19"Russia's Greens: The Poisoned Giant wakes Up,"The Economist, 4 Novenber 1989, p. 26.

20 see zhores A. Medvedev, Soviet Agriculture, (New York, London: *. Norton and Company, 1987), pp. 288-90.
} 
investments and therefore did not figure into the national accounting of gross social product, the rough equivalent of the Western measurement of gross national product. In the West, pollution control and abatement expenditures are included in the G.N.P. ${ }^{21}$ The ramification is that policies will not favor activities that do not contribute to a higher gross social product. Underlying this omission of antipollution expenditures in G.S.P. was a philosophy that placed little importance or worth in them. Furthermore, on the micro level, waste control and cleaning costs were secondary, not primary, costs, creating the impression that they were optional. 22

The divisions within the centrally planned economy were not conducive to proper environmental management. The narrow industrial divisions (chemicals, petroleum processing, petroleum extraction, etc.) and their corresponding environmental responsibility within their sector defied appropriate solutions to ecological problems, which, by their very nature, cut across many branches at once. DeBardeleben notes that, while the dominant principle of economic organization was functional, ecological problems are territorial, focusing on the maintenance of proper

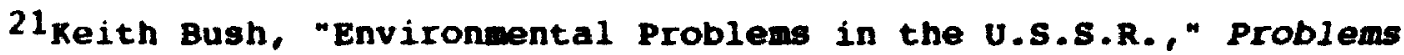
of Communism, July-August 1972, p. 27.

22E. U1itina, "Na puti $k$ effektivno: prirodookhrannoi sisteme," IOn the Way to an Effective Nature Protection Syscem, ] Voprosy ekonomiki, 11 (1990), p. 104.
} 
surroundings.23 The design was flawed from its very

inception: both economic and environmental decisions were made from Moscow and carried out along functional 1 ines. Environmental decisions should most logically have been made regionally, where they are most acutely recognized.

\section{The Pricing Byten}

One of the major stumbling blocks to enacting adequate environmental policies was the Soviet pricing system. At its heart was Marx's labor theory of value, which, in essence, says that the worth of a product is determined solely by the labor that went into making it. In his first volume of Capital, Marx states:

We see, then, that that which determines the magnitude of the value of any article is the anount of labor socially necessary, or the labor-time socially necessary for its production.... Commodities, therefore, in which equal quantities of labor are embodied, or which can be produced in the same time, have the same value. The value of one commodity is to the value of any other as the labor-time necessary to the production of the one is to that necessary for the production of the other. 24

What this means, then, is that a pound of diamonds is worth the same as a pound of coal, if the human labor that went into bringing them to their present states is the same. The implications of the labor theory of value are manifold and profound, leading to egregious price distortions.

23DeBardeleben, The Environment..., p. 219.

${ }^{24}$ Rarl Marx, Capital, A Critical Analysis of Capitalist Production, ed. Frederich Engels, trans. Samuel Moore and Edward Aveling, (New York: Humboldt Publishing Co.: 1890), p. 4. 
Rider College's Leonore Shever Taga, who closely studied the soviet forest industry, speaks of two types of price failures. The first is the absence of prices.25 In adhering to Marx's philosophy, the Soviet Union had not traditionally charged users of water, land, minerals, and other resources, because they had to be treated as free goods, according to the labor theory of value. The Principles of Land Legislation (1968), of Water Legislation (1970), and of Legislation of the U.S.S.R. and the Union Republics on the Earth's Interior (1975) all affirmed the right to free use of resources.26 Industry had little incentive, then, to conserve or recycle.

The second price failure is the existence of prices that do not reflect social value. 27 Limited and, in some cases, temporary, reforms in the pricing system have led to charges for timber, water, mineral, and electricity use, as well as for disruption of land by non-agricultural users.28 However, the fees incurred were not accurate enough to stimulate rational resource use. As DeBardeleben puts it, "The fact that prices in the...U.S.S.R. do not reflect variations in supply and demand or in marginal costs aggravates the

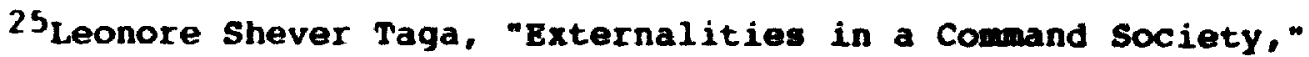
Environmental Misuse in the Soviet Union, ed. Fred Singleton, (New York: Praeger Publishers, 1976), p. 84.

26DeBardeleben, The Environment.... p. 244 .

27 Taga, p. 84 .

28 DeBardeleben, The Environment... PP. 244-245.
} 
difficulty of attempts to define charges for natural resources which will encourage rational use." 29 At the factory level, managers and ministry of ficials could not determine the true opportunity costs of their various inputs and outputs, so resources could not be combined in an efficient manner, nor could the true costs of environmental disruption be calcuiated. 30

\section{Industry}

In keeping with the Marxist philosophical principle of industrialization, leaders pushed the economy ahead as quickly as possible and, with the great wealth of resources at their disposal, relied on economic expansion through, among other things, greater input use, rather than better utilization of inputs like the upgrading of technology or worker skills; ${ }^{31}$ that is, the economy relied on extensive rather than intensive means. Thus, a 1983 study shows the Soviet Union consuming 32.3 megajoules of energy per dollar of G.N.P., as opposed to 19.3 in the United States, which itself is not very efficient relative to many other countries. 32 The need for greater quantities of inputs, of course, means greater disruption in extracting them and

\footnotetext{
29DeBardeleben, The Environment..., p. 246.

${ }^{30}$ Gregory and stuart, pp. 202, 378.

${ }^{31}$ Gregory and stuart, p. 423.

32 Hilary F. French, "Industrial wasteland," wurld watch,
} November/December 1988 , p. 28. 
greater pollution as more unergy, like oil or coal, is expended per unit output.

Mote remarks that, perhaps partly in response to the poor quality and general absence of pollution control equipment, Soviet industry relied more on "dilution technology," that is, very tall smokestacks and the so-called "sanitary protective zones" that served as buffers around offending plants, at least where air pollution was concerned. 33

Industrial output in the U.S.S.R. Was concentrated in the heavy industries, with a huge military-industrial complex which, for security reasons, was permitted to pollute with impunity. The emphasis on heavy industry meant that enormous support facilities, like hydroelectric power stations, were needed to insure that factories rould churn out steel and armaments at a dizzying pace. The gigantism was supported by the economic ministries and other powers that be as a means of hoarding power by maintaining monopolistic control over particular branches. ${ }^{34}$ The huge projects completely altered the landscape of the country. Some of them were ecologically disastrous in less obvious ways. For instance, the mini-

\footnotetext{
${ }^{33}$ victor L. Mote, "The Geography of Air Pollution in the Soviet Union," Environmental Misuse in the Soviet Union, ed. Fred Singleton, (New York: Praeger Publishers, 1976), pp. 3-4, 20.

34 M. Lexeshev, "Ekonomika i ekologiia: rokovoi konflikt i puti ego razresheniia," [Economics and Ecology: the Fatal Conflict and ways to kesolve 1t, ] Voprosy ekononiki, il (1990), p. 73.
} 
steel plants operating in the United States are 2 to 3 times more energy-efficient than their large counterparts. 35

The obsession with gigantism was a trademark of Soviet rule. While some of the projects arguably arose from necessity, like some of the massive factories which were transplanted from European U.S.S.R. and concentrated in the Urals to evade the advancing Nazis in World War II, 36 the vast majority was deliberately planned and carried out by the Soviets.

If there is a silver lining to be found in the dark cloud of hr avy industry, it is that the traditional lack of emphasis on consumer products resulted in less waste and consumption: the waste in excess packaging and disposable products, the 'buy new and discard the old' mentality, and the pollution emitted by and erergy consumed by appliances, private cars, and so on, were all, for the most part, absent in the U.S.S.R. In fact, Victor Mote concluded in a 1976 study that "...the relative lack of air pollution in the Soviet Union is nor a result of better management but of a still-lagging industrial economy and the relative lack of the automobile." 37

Shortages of goods and services were rampant. Because enterprises, not to mention households, of ten had difficulty 1992.

${ }^{35} \mathrm{Gel} \cdot$ vanovskii and Trofimova, p. 135.

${ }^{36}$ Don Murry, "C.B.C. National," television broadcast, is Steptefembry 37Mote, "The Geography...," p. 20 . 
obtaining adequate supplies, hoarding was not uncommon. Hoarded stocks often must eventually be replaced, either because they have rotted or deteriorated through time, or because they have become obsolete and no longer can serve the purpose for which they were originally set aside. Of course, this is a waste of the resources involved in both the products themselves and in the storage process. Also, items that could have been fixed and continued to be used often had to be scrapped.

Lack of incentives and interdepartmental cooperation exacerbated the supply problem, and as a result, ecological problems. In his well-known samizdat work on the Soviet environment, Boris Komarov explains that factory by-products that were of ten treated as waste could, in many cases, have been shipped to ancther plant as secondary raw materials where they may have been needed in the production process. Even when efforts were made to exchange secondary raw materials, the process could take several jears to implement. ${ }^{38}$ In the capitalist world, this transaction would be a more simple matter, expedited by the profits to be made by the seller.

\section{Agricuiture}

Environmental disruption vis-à-vis agriculture is a common problem throughout the world, yet it deserves special mention here because of the unique place agriculture held in

$38_{\text {Komarov, p. } 137 .}$ 
the Soviet system, namely, the Soviet obsession with improved agricultural output. Agriculture proved to be a perennial thorn in the side of Soviet planners. Much of the territory is either too cold or too hot, too wet or too dry, or too mountainous, while the soil often tends to be of too poor quality to be of any agricultural use. ${ }^{39}$ For these reasons and others, the Soviet Union tended to throw many resources into and take many approaches to heightened agricultural production, with limited results. As Thane Gustafson stated in 1981," "...agriculture has undoubtedly received the leaders' sustained attention and priority, for over the past fifteen years, agriculture, conservation, and related programs have been the fastest-growing sectors of the Soviet economy-faster growing, in fact, than the military."40

In the U.S.S.R., nearly all arable land was sown. 4 Expansion of agricultural zones resulted in grave environmental disruption. Natural vegetation was cleared, swamps were drained, dry land was irrigated, and fertilizers and pesticides were heavily applied, all having an impact. Heavy and reckless deforestation was all too common. The practices have many causes, among them the need for exports of timber to bring in hard currency, the under-valuation of the land so that users have little regard for the

\footnotetext{
${ }^{39}$ Stefan Hedlund, Crisis in Soviet Agriculture?, doctora] dissertation, (Lund, Sweden: University of Lund, 1983), pp. 19, 20.

${ }^{40}$ Gustafson, p. 8 .

41 Hedlund, p. 21 .
} 
consequences of their actions, and the need to put more land into cultivation.

Production of effective forms of fertilizer traditionally lagged behind most other countries. At last report, farmers were still using physiologically imbalanced forms, like potassium chloride and sodium nitrate, which, when mixed together, yield sodium chloride, leading to increased soil salinization. 42 Moreover, the processes of granulating fertilizer and producing complex granules, that is, granules containing specific proportions of alements and microelements for different crops, are still in their infancy. Among other things, proper granulation helps keep fertilizer from leaching, 43 which presents problems with regard to surrounding bodies of waters.

Because of a shortage of covered trucks and rail cars, some fertilizer simply blew away in transit. A report in the early 1980 's estimated in transit losses at 626 thousand tons country-wide. ${ }^{44}$ The situation gets more bleak. Because of a lack of interdepartmental coordination, the Ministry of Chemical Products failed to supply enough plastic bags for fertilizer shipment and storage. Then, because of poor transportation links, fertilizer was often merely dumped at railway sidings, instead of being taken to the appropriate

\footnotetext{
42 Medvedev, p. 304 .

43 Medvedev, p. 305.

$44_{\text {Hedlund, p. } 200 .}$
} 
farms. Finally, poor communication between shippers and the farms sometimes resulted in the wrong kind of fertilizer being delivered; these shipments were not usually returned. but simply left in a useless pile. The same 1980's estimate placed the loss of fertilizer in transport, storage, and handling at 9 million tons per year, or ten percent of total output. 45

Agriculture played a further role in determining environmental conditions. Nove points to the problems surrounding plan fulfillment. The Ministry of Water Resources was assigned to assist farms in improving and extending agricultural zones. Yet, the chief criterion for assistance was the gross value of the work involved. This meant that capital intensive activities, like draining unused lands, using the most expensive materials, and choosing the worst land because it is the most costly to improve, took precedence 46 and resulted in greater environmental discord.

\section{THE socIo-POLITICNL SETTING}

Another root of Soviet environmental destruction lay in the Soviet socio-political structure. The absence of a central environmental authority, a tight grip on information dissemination, few opportunities for private organization and input through the media, traditional views on the scope of

45 Hedlund, p. 2015.

46. Alec Nove, Soviet Agriculture: The Brezhnev Legacy and Gorbachev's Cure, (Rand/U.C.L.A. Center for the Study of Suviet International Behavior, 1988), pp. 18-19. 
the country's resources, and the educational system are but a few of the factors that fostered the current environmental crisis.

\section{Rcological Mdninietration}

Policy-making was the domain of a few individuals during the years of Soviet power. The party leadership and the decisions this small elite made were supposed to be faultless, obviating the need for input from below and making dissent intolerable. Despite some pluralization of the policy process in the years following Stalin's death and a more or less greater toleration of dissent, there remained relatively little input from common people, specialists, and special interest groups. According to Gustafson, however, by the early 1970 s, along with increased financial attention to environmental problems came a "...much more elaborate incorporation of environmental concerns into the formal structure of government." He cites water codes and legislation, additions to the national economic plan, a new division for the environment within Gosplan, and other reforms. 47

Under Soviet authority, nearly all political decisions emanated from the center, leaving local bodies fairly impotent. In the environmental field, central administration was dispersed among many different ministries and agencies. In 1978, the Hydrometeorology Department was expanded to the

\footnotetext{
${ }^{47}$ Gustafson, pp. 50-51.
} 
State Committee for Hydrometeorology and Environmental Control, or Gosgidromet. It was responsible for monitoring air and water, inspecting factories, with the ability to shut them down if necessary, and ensuring compliance with standards and regulations. Under Gorbachev, the Committee underwent an assessment, and was found wanting; the body lacked real enforcement powers in the face of the powerful economic ministries.48 The establishment of Goskompriroda, the State Committee on Environment, in 1988 placed environmental concerns under the authority of one agency and was to do away with coordination and enforcement problems, inter-agency rivalries, and questions of economic selfinterest. Although its first director, Fiodor Morgun, resigned after just 15 months, the subsequent appointment of Nikolai Vorontsov, a highly regarded scientist, gave renewed hope. 49 Under Goskompriroda were corresponding bodies at the republic and local levels.

With the dissolution of the U.S.S.R. at the end of 1991 . the Ministry of Ecology and Nature-Use, a new unit for environmental concerns within Russia, was established. Further consolidation of environmental duties took place, with the new ministry incorporating other environmental

\footnotetext{
${ }^{48}$ Philip R. Pryde, Environmental Management in the Soviet Union, (Cambridge, England; New York; and Melbourne: Cambridge University Press, 1991), p. 9.

49Hilary F. French, "Green Revolutions: Environmental Reconstruction in Eastern Europe and the Soviet Union," Wor ldwatch papr.t 99. Norldwatch Institute, November 1990, pp. 34-35.
} 
bodies, with the exception of the State Sanitary and Epidemiological Service, which also has a local counterpart. 50

\section{Information and Media}

The Soviet Government was wont to ward off criticism, both foreign and domestic, by obfuscation and lies. This is especially true in the environmental field. Reports abound concerning suppressed information and outright lies about environmental dangers.

In the West, grass roots and private foundations have been in the forefront of environmental affairs, serving as watchdogs of industry and government. These groups both generate and depend on information. With the ability neither to collect nor to disseminate data, a major link in the environmental safety chain was broken. Tatiana zaharchenko of the Kharkov Law Institute points at this shortcoming as culpable in environmental problems: in the Soviet Union, the public had no right to know. There was no equivalent of the Freedom of Information Act as in the United States, and without this mechanism, people did not know who was polluting, what the quality of their air and water was, etc.; in short, they had no hard numbers or facts with which to fight.51 An ignorant populace cannot take informed actions to ensure that it lives in a safe and healthy environment. As

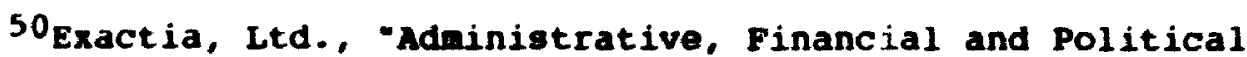
Preconditions for the Protection of Environment in St. Petersburg," Interim Draft Report to the Finnish Ministry of Environment, January 1992, section 3.1.2.

51 zaharchenko, personal interview. 
Academy of Sciences Researcher Valerii Karpov notes, "How can we discuss whether Tchaikovsky's first concerto is good or bad if we haven't heard it? How can we discuss the environment if we have no information?"52 Marshall Goldman, in his introduction to Boris Komarov's work, cites mistakes in the book, evidently demonstrating that "...even specialists in the Soviet Union have trouble obtaining access to all the materials." 53

Data may have been deliberately withheld from public scrutiny, but the methods of collection and analysis of information on the environment also hampered any meaningful use of the data. In the U.S.S.R., environmental research was conducted by 1,065 institutions under seven different ministries. In some cases, one department would collect information, another would analyze it. To make things even worse, data was not always comparable: each institution had its own methodology for collecting, compiling, and interpreting data. 54

The Soviet Government's refusal to present forthright and adequate information was not limited to its own people, but included foreign bodies as well. This hampered international agreements and information and technological

52 valerii Karpov, personal interview, 24 November 1991, St. Petersburg, Russia.

53 Marshall Goldman, foreward, The Destruction of Nature in the Soviet Union, Boris Komarov, trans. Michel Vale and Joe Hollander, (White Plains, NY: M. E. Sharpe, Inc., 1980), p. $x$.

54 peterson, "...An Overview," p. 15. 
exchanges, setting back Soviet environmental maintenance and clean-up, particularly in light of the great expenses involved in this realm. Partly as a result, the Soviet Union lagged behind the West in environmental protection. Leaders did sign, however, many bilateral and international treaties on environment, and hosted international conferences on the subject. In fact, it has been noted that environmental and tanyential topics remained a sacred cow, of sorts, in U.S.Soviet relations, surviving even the worst moments of the cold war. 55

In addition to limiting availability of statistics and records, the government also placed restrictions on the media, limiting the fora through which opinions could be voiced and the pros and cons of particular issues could be weighed. This began with Stalin's consolidation of power, with publications being either banned or coopted by the government. For example, the journal okhrana prirody [Protection of Nature], published by the All-Russian Society for Conservation and premiering in 1928, began as an educational publication and no subject was deemed taboo; early issues even included an article on the positive role of shamanism, and questioned the ecological soundness of the first Five-Year-Plan and collectivization. 56 As pressures increased with Stalin's rise to power, however, the journal

\footnotetext{
${ }^{55}$ See Fitzhugh Green, "The Amerikanskis Are Coming," E.P.A. Journal, January/February 1986, p. 22.

56weiner, Mode1s..., pp. 49, 121-122.
} 
and other publications found themselves bound to ideological dicta, becoming ever more impotent and subjective, and Okhrana prirody even changed its name to Priroda $i$ sotsialisticheskoe khoziaistvo [Nature and the Socialist Economy. $]^{57}$

Following the stalin era, restrictions were relaxed somewhat and numerous publications with an environmental emphasis came into existence, among them Ekologija [Ecology] and Priroda $i$ chelovek [Nature and Humanity].

While there can be no doubt that the gagging of critical and dissenting views lessened following Stalin's death, problems remained. The voicing of opinions about the environment was relatively more open than that of other areas, so long as the opinions did not fundamentally challenge prevailing ideology.58 Even recently, many in the environmental field in the U.S.S.R. continued to complain that there remain closed topics and limited access to the media. Andreii Sakharov, for instance, said at a conference on environment and human rights in 1989 that there were still limits on free speech, even within the Congress of People's Deputies.59 Although there were many cases of open debate on

\footnotetext{
57 weiner, Models.... p. 146.

58 Joan Debardeleben, "The New Politics in the U.S.S.R.: The Case of the Environment," paper presented to the IVth World Congress for Soviet and East European studies, Harrogate, England, 21-26 July 1946 , p. 2.

59Andreit Sakharov, comments at conference "Human Rights dind the Future," Berkeley, California, 11 August 1989.
} 
environmental problems, there were also many taboo areas. Limits expanded and contracted, but basically, as political scientist Samuel Huntington notes, "The limits of dissent are set by the fundamentals of the systeil, of which the party's monopoly of ultimate authority is the most sacrosanct." 60 We see then that as long as these fundamental philosophical notions, including the economic concepts already explored, were not questioned, other opinions, to a greater or lesser extent, could be expressed.

\section{Education}

The socio-political sphere also encompasses education, both formal and informal. Perhaps surprisingly, conservation topics had long been a part of school curricula in the U.S.S.... albeit often from biased or erroneous points of view.61 Much was made of environmental problems in capitalist countries, while domestic problems were not explored. Resources were regarded as and taught to be limitless, with an emphasis on the utilitarian aspect of nature. The rules for membership in the Pioneers included the following: "The Pioneer loves nature; he is a defender of planted trees, of useful birds and animals."62 And from the earliest times, education has traditionally placed an emphasis on the

${ }^{60}$ Quoted in DeBardeieben, The Enviroment.... p. 13.

${ }^{61}$ Pryde, Environmental Management.... Pp. 246-247.

${ }^{62}$ Quoted in Gordon B. Smith, Soviet Politics: Continuity and Contradiction, (New York: St. Martin's Press, 1988), p. 47, my emphas is . 
transformation of, rather than cooperation with, nature. A school primer from the early post-N.E.P. period concerning the first Five-Year-Plan contains many references to the need to master nature. The primer talks of limitless forests and peat bogs, of taking as many raw materials as one wishes, while a recurrent philosophy is one that virgin nature is of no use; only in its utilitarian capacity is nature beneficial. "...[C]an we command the sun to shine or not to shine? Can we command the rain to fall or to cease falling?" the textbook asks. "No, we cannot. Does this mean that man is powerless in the face of Nature? No, here also we may carry on a warfare with Nature... We can force Nature to obey." is the answer. ${ }^{63}$

The megalomania cescribed earlier was reflected in the environmental sphere as well, with the country's natural environment being described in a wealth of superlatives. The repercussions were disastrous. For one thing, this thinking reinforced the notion that the country's natural resources were virtually infinite. 64 What is more, the vastness of the country implied not only an unlimited supply of resources, and thus no need for conservation, but also an infinite ability of the land, water, and air to absorb whatever wastes were poured into them. And the common person was not the

$63_{M}$. Ilin, New Russia's primer: the story of the tive-yeal platl, trans. George $S$. Counts and Nucia P. Lodge, (Cambridge, Massachuset $s$ : The Riverside Press, 1931), pp. 18, 27-28, 52, 142, 106-107.

${ }^{64}$ Charles E. 2iegler, "Suviet Images of the Envisonnent," Brstst" Journal of Political Science, 15 (1985), p. 367. 
only one to hold this view: as ziegler points out, "For many years, Soviet scientists and of ficials found it difficult to believe that these resources could be exhausted in the near future." 65

\section{The Environmental Movement}

Beginning with the late 1920 's, new 'socialist' views of science and politics emerged, Iike the superiority of ideology over practice, dogma over objective sfience, and the purely utilitarian use of nature over the rational and esthetic. Douglas R. Weiner closely follows this history. detailing how many of the great conservationists of the prerevolutionary and N.E.P. periods were jailed, executed, driven out of the profession, or relegated to menial work as the changing political environment swept the country.66 A host of intellectuals disappeared from the ecology scene, and one can only speculate that the brain drain badly hurt the country's ecology, as the movement lost both its best minds and its strongest advocates.

The lion's share of non-governmental work in the ecological sphere was carried out by the Central Bureau for the Study of Local Lore, formed in 1922, and the Al1-Russian Conservation Suciety, formed in 1924 and focusing primarily on pubijic education on environment. 67 Besides these groups,

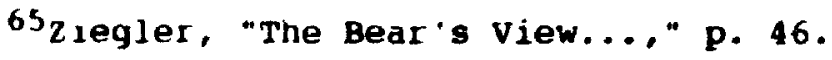

${ }^{66}$ weiner, Models..., pp. 124, 219, 222.

67 Weiner, Models..., pp. 45, 47 .
} 
the Young Communist League (Komsomol), trade unions, scientific and technical societies, monument-protection groups, tourist organizations, and fishing and hunting groups also participated in environmental protection. 68

Unfortunately, in the pre-Gorbachev era, environmental groups were few in number and operated under government auspices. According to ziegler, the groups usually simply advocated points of view reinforcing the dominant social paradigms, with only minor modifications, and as such did not fulfill watchdog and advocacy functions. 69 In fact, leaders of the Society for the Protection of Nature had traditionally been spokespersons for industry, with the head of the Russian branch at one time also serving as the first-deputy minister of the Ministry of Land Reclamation and Water Management of the Russian Republic, one of the major culprits in environmental disruption. 70

Without independent groups and their watchdog and lobbying functions, government, industry, and agriculture polluted with impunity, while the proscribing of criticism deprived the process of valuable feedback. M.I.T. professor Lo-en Graham decried the absence of grass roots groups in the

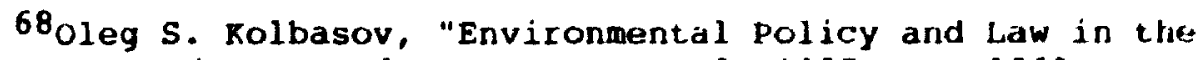
U.S.S.R.," Environmental Law Reporter, 3 (1987), p. 1069.

${ }^{69}$ ziegler, "Soviet Images...." pp. 378-380.

70marshall I. Goldman, "Pollution in the Soviet unjon: The Growth of Environmentalism and Its Consequences," Soviet Socjal Problems, ed. Jones, Connor, and Powell, (Boulder; San Francisco; and oxford: Westriew Press, 1991 ), p. 40.
} 
Soviet Union, saying their presence could have made a difference in environmental policy and practice. Graham believes a disaster like Chernobyl may never have happened if the original construction decisions had not merely been left up to scientists, engineers, and bureaucrats.

Environmentalists, he opines, would have noted the site's proximity to the Dnepr-Teterev State Nature Preserve; citizens from Kiev would have objected to building such a plant near a river that feeds into their main drinking water supply; Ukrainian nationalists would have pointed out the historical significance of the area and the ancient churches located there; Belarusan nationalists would have clamored for a say in building a ruclear power plant on their border; and peace activists would have questioned the uses planned for the weapons-grade plutonium produced at the plant.71

In contrast to Craham's notions about Chernobyl and pluralist input, one official typified the party line when, on 27 May 1986, shortly after the Chernobyl catastrophe, he was interviewed by a Western journalist. Ivan Emalianov, Deputy Director of the Institute of Power Engineering, was asked how necessary and helpful public opinion is in the question of nuclear energy use. His immediate and clear-cut reply: "I an not convinced that scientific progress can be

$71_{\text {Loren }} \mathrm{R}$. Graham, "Soviet Science Needs Dissent," The Washington Post, is June 1986, p. F5. 
influenced by people's opinions. It is an objective process that proceeds according to its own rules." 12

Beginning with the era of glasnost, the environmental movement took root and grew throughout the country. In 1990, one national group, the Social-Ecological Union of the U.S.S.R., published a list of 331 environmental groups in the country, 235 of them in Russia. 73

\section{Environmental Law}

Soviet law is often viewed as a culprit in environmental degradation. First is the question of the lack of specificity in Soviet law. In general, environmental law relied on hortatory provisions. ${ }^{74}$ Instead of precisely prohibiting deleterious actions or instituting standards with which individuals and industries must comply, the law simply exhorted them to actions compatible with socialist life.

These pronouncements were igrored. Where legal standards did exist, they were of ten simply unrealistically high and thus unattainable. Also, the extent to which an enterprise could be fined had been set artificially low, with a 100 ruble maximum levied against environmental law violators. ${ }^{75}$

Legislation concerning air and water resources, like the "Soviet Law on Atmosphere Protection" and "Water

\footnotetext{
${ }^{72}$ Chiesa Giulietto, L'Unita, 27 May 1986: 4; Furesgn Broadcast Information Service, 5 June 1986, p. R4.

${ }^{73}$ Pryde, Environmental Management.... p. 253.

74 Bush, "Environmental Problems...," p. 28.

${ }^{75}$ zaharchenko, personal interview.
} 
Legislation," set ecological requirements for polluting sources. Under these laws, discharges of pollutants were set on the basis of maximum allowable concentrations of harmful agents after dispersion into the atmosphere or dissolution in the water. By regulating only the concentration of pollutants but not their totals, nothing stopped enterprises from merely diluting effluent, rather than actually reducing it, to meet the requirements. ${ }^{76}$ These regulatory methods remain in use.

often the laws themselves were not at fault, but numerous inherent and external defects in the legal system failed to prevent disruption. Legal jurisdictions overlapped with regard to republic versus union laws. Each republic had, by 1963, passed its own laws on the preservation of nature. These laws, then, included the whole of the Soviet Union, so there was apparently no need for a similar national law. Yet, in practice, the republics were powerless against the chief polluters, the industrial enterprises, because the enterprises were accountable only to Moscow. ${ }^{77}$

On the whole, Soviet environnental law simply did not reflect the economic aspects of the problems. ${ }^{78}$ In other words, as long as the central planning system continued and

\footnotetext{
76 ronsofin (Jaakko Pöyry oy and Giprobum, Leningrad), "Environmental situation and Project Identification in Leningrad and Leningrad Region," Helsinki: 1990, p. 46.

${ }^{77}$ Komarov, pp. $94-95$.

78 zaharchenko, personal interview.
} 
economic ministries remained all-powerful, the laws were impotent. As an example of the ineffectiveness of the laws, then Minister of Public Health Chazov acknowledged in 1987 that, "Of the 196 environmental protection assignments stipulated in Party and government resolutions, only 47 have been fulfilled."79

One Soviet writer cites a jurist who indicted the republican laws on conservation:

First, punitive measures are not applied to the fullest. Second, they are not applied fairly. Third, in a huge majority of cases, they are not applied at all. Too often these measures-a fine or occasionally a prearranged term of imprisonment-do not correspond to the magnitude of harm done to nature; they are far lower. Too often the punitive measure is devoid of any moral force, since in the dock sits not the real culprit but someone who carried out illegal orders. The judge and the defendant both know this, and the trial is turned into a game. It is known by all that the attitude of the factory toward the environment greatly depends on instructions from the industrial section of the regional or city party committee, on the need to provide a plan at any price. However, all instructions from the regional committee are given in such a way that the committee cannot be held responsible under any law. 80

In this way, environmental accountability was ignored when it came to the economic ministries.

According to Zaharchenko,"...the weakest link in the Soviet Union's system of legal protection for the environment

Tivuoted in 5 . Frantsen, "On the Most vital question in the Sor:al Sphere: Formula for Health, "Pravda, 13 April 198\%: 3; Current vigrst of the soviet Fress, 15 (1987), p. 19.

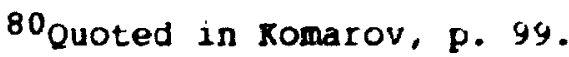


has been law enforcement." 81 An article in Ekonomicheskaia gazeta in 1979 charges that, in the period from 1975-77, investigative agencies considered only one third of the cases presented to them, and brought charges against just 258 of the violators. "The failure to punish violators," the article admonishes, "is definitely conducive to new breaches of legislation." 82

When fines were levied, the system often channeled them, not toward the cleanup or restoration of the problem areas, but into the state budget. 83 In this way, money was merely redistributed from one governmental body to another. Furthermore, in an article in the early $1970^{\prime} \mathrm{s}$, Radio Liberty Senior Researcher Keith Bush noted that municipal governments used fines collected from enterprises to finance construction of parks and clubs, so there was a civic stake in continued pollution. 84

Communication and awareness of laws, even by those directly involved, was not assured under the Soviet legal system. Obviously, laws cannot be enforced o:, for that

81 Tatiana Zaharchenko, "The Environmental Movement and Eculogical Law in the Soviet Union: The Process of Transformation," Ecology Law Quarterly, 3 (1990), p. 470 .

$82 \mathrm{v}$. Koldobsky, "The Land Is Not Just the Grain Growers' Concern," Ekonomicheskaia gazeta, 37 (1979): 19; Current Digest of the Soviet Press, 37 (1979), p. 16.

$$
\begin{aligned}
& { }^{83} \text { Komarov, p. } 101 \text {. } \\
& { }^{84} \text { Bush, "Environmental Problems...." p. } 29 .
\end{aligned}
$$


matter, obeyed, if involved parties are not aware that they exist. 85

No national law mandating environmental impact analyses existed in the Soviet Union. Despite the common practice of preparing studies for individual projects, there was no law ensuring that alternatives be reviewed, that mitigating measures be taken, and that these steps be completed prior to the start of work on each significant project in the country. 86

Because of the labor theory of value, laws concerning the payment for use of land and resources traditionally led to waste and environmental disruption. It was not until 1987, with the passing of the Law of the state Enterprises of the U.S.S.R., that every enterprise in the country had to pay for the use of land, water, and other natural resources. ${ }^{\prime \prime}$ Before then, as explained in the section regarding the labor theory of value, these commodities were free under state ownership. Farmers, likwise, had no stake in preserving their plots until a fairly recent law gave them the right. to lifelong possession of the land with the right to inher:.. zaharchenko asserts that this situation had a devastating effect in shaping psychological attitudes of the peasants.

${ }^{85}$ See Komarov, pp. 99-100.

${ }^{86}$ Philip R. Pryde, "The Future Environmental Agenda of the U.S.S.R.," Soviet Geography, June 1988, p. 560.

${ }^{87}$ Zaharchenko, "The Environmental Movemunt..., p. 46,8.

${ }^{88}$ zaharchenko, "The Environmental Movement...," p. 46,y. 
Why, she asks, should peasants care how well they take care of the land if it does not belong to them?89 Under capitalism, the owner of the land must act responsibly if s/he wishes the land to retain its market value; a plot of polluted land would neither fetch much money on the auction block nor be worth passing on to the next generation.

The basis of current environmental law has its roots in Soviet legislation. When Russia declared union legislation void in its territory in November 1991, it adopted, more or less, the premises of the previous union law. Russia adapted the law, however, to changing circumstances; namely, the question of union vs. republic was made moot and the move to privatization was more firmly entrenched. Importantly, the law also delegates powers to the local level and allows considerations of local conditions when necessary.90

The roots explored here are characteristic of the Soviet Union as a whole. While the most important of these without a doubt are economic, all the factors have, taken together, helped to define the development of environmental problems in St. Petersburg. This paper will now examine those factors unique to the Leningrad region that, together with these national policies and practices, gave rise to the environmental crisis in St. Petersburg.

\footnotetext{
${ }^{89}$ Zaharchenko, personal interview.

90 Exactia, sections 4.1-4.2.
} 


\section{LOCAL FACTORS IN ENTIROMALATAL DISRUPTION OF ST. PETYRSBURG}

The manifold environmental problems currently confronting St. Petersburg are attributable not only to national policies and practices, but also to local factors. The region has a special history and setting that have uniquely shaped it environmentally. Following is a detailed analysis of the local contributions to the situation as it now exists in St. Petersburg.

\section{THE GBOGRAPHICAL SETTIMG}

St. Petersburg's environmental situation has largely come about because of its geography. The area is one of the border regions mentioned in the previous chapter that imports pollution from outside its boundaries. Because parts of it lie within the Ladoga catchment area, Finland exports pollution to the St. Petersburg region. The river Vuoksa, for example, brings pulp and paper industry pollution to Ladoga from Lake Saimaa within the Finnish borders.' As well, with Narva's heavily polluting industry just across the border in Estonia, St. Petersburg receives, especiaily through prevailing winds, a large dose of pollution, particularly sulfur. ${ }^{2}$

\footnotetext{
1 Jorma Rorhonen, "Juomavettä viemärist\&," IDrinking water from the Sewer, J Belsingin Sanomat, 27 September 1992, p. C9, summarized in English for the author.

2ministry of the Environment of Finland, "Envirunmerte. Priorlty Action Programme for Leningrad, Leningrad Region, Karelia al.. "Istonsi: Synthesis Report," September 1991, p. 9.
} 
Becouse of its high latitude, the northern ecosystem of the Leningrad region makes it highly vulnerable to environmental discuption. In addition, the area is abundantly surrounded by a large zone of taiga forest, and includes large reserves of minerals, but few natural fuel resources. ${ }^{3}$

In any case, the area is best known for and has been most influenced by the surrounding water resources. Excess precipitation over evaporation in the region insured dense network of approximately 20,000 rivers and streams, totaling $11,000 \mathrm{~km}$. in length, ${ }^{4}$ with thousands of lakes and smaller bodies dotting the area as well. St. Petersbirg is inexorably linked with the surrounding bodies of water, from the swamp land the city was built upon, to the proximity of Lake Ladoga, whence the city draws its water, to the Baltic Sea, which serves as the city's gateway to the west. The region was blessed by an abundance of water resources, which have played a role in its history, from its very founding, to its economic development.

Lake Ladoga and Nevskii Bay on the Gulf of Finland, part of the Baltic Sea, are the two dominant bodies of water. They are also the two main areas of concern. These two water bodies, along with the region's atmospheric conditions, will be examined here in the geography section in detail, even though the problems affecting them, like the cattle farms

\footnotetext{
3 KONSOF IN, P. 6 .

$4_{\text {RONSUFIN, p. } 3 .}$
} 
around the lake, the dam in the gulf, and the factories spewing pollutants into the air are, of course, a result of the economic and socio-political history of the region, both of which will be explored later.

\section{Lake Ladoga}

Lying some 65 kilometers from St. Petersburg, Lake Ladoga is of utmost importance for the region because, along with the Neva River, it is the main source of fresh water for the city of St. Petersburg and the Leningrad Oblast. 3354 million cubic meters of water were used from these two sources in 1988.5 Lake Ladoga is the largest fresh-water lake in Europe, covering 17.7 thousand square kilometers and containing 908 cubic kilometers of water, while its catchment area covers some 276 thousand square kilometers. 6

Within the basin are 50 thousand lakes. 3,500 rivers over ten kilometers in length, 7 and over half of the Leningrad Oblast, about 45,000 square kilometers, the rest of the oblast being found in the rivers draining directly into the Gulf of Finland. 858 of Ladoga's inflow comes from rivers, mostly from the Svir', Vuoksa, and Volkhov, while 928 of the lake's outflow moves solely through the Neva River," which

${ }^{5}$ Gosudarstvennyi Romitet, pp. 66-67.

${ }^{6}$ Bol'shaia sovetskaia entsiklopediia, (The Gredt Suvtet Encyclopedia, ) third edition, (Moscow: "Soviet Encyclopedia" publishing House, 1973), vol. 14, p. 101 .

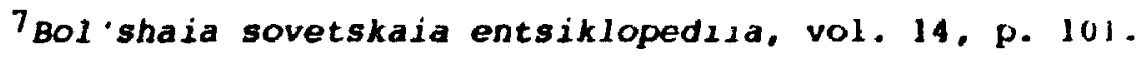

Bronsofin, p. 3 .

${ }^{9}$ Bol'shaia sovetskaia entsiklopedisa, vol. 14, . . 101. 
wends its way through St. Petersburg. The Svir' flows from Lake Onega, located mostly in the Karelia Autonomous Republic, to Lake Ladoga. Although Lake Onega does border on the Leningrad Oblast, it is not of chief concern because of its peripheral location, and will be dealt with here only insofar as it relates to Lake Ladoga.

Ladoga's beauty and size, the easy access to large amounts of fresh water, and the nearby forest reserves have proven to be the lake's undoing, as population centers, factories, and farms formed around it. The large basin draining into the lake and the Neva means much waste from industry, agriculture, and other human activity makes its way into these bodies.

Although initial reports of serious water pollution of Lake Ladoga appeared as early as 1967,10 concerns existed well before then. In the $1950^{\prime} \mathrm{s}$, the question of constructing a plant for the production of durable cord for bomber tires was addressed. The plant would have had to have access to large quantities of very clean water, narrowing the choice of a site to Lake Ladoga or Lake Baikal. The Leningrad Regional Committee, however, categorically rejected the plan, since Ladoga was already surrounded by much industry and was to remain the chief source of drinking water for the city and surrounding area well into the future. The decision

10pryde, Environmental Management..., p. 82. 
ultimately sealed the fate of Baikal, which was chosen as the site for the plant.1:

It is noteworthy that, while the Siberian and Ural river diversion projects are well-known, a similar scheme had been proposed for the Leningrad region in the $1960^{\circ} \mathrm{s}$. It involved reversing the flow of waters from Lake Ladoga to the Caspian Sea. According to the two scientists who proposed the plan, it was not fair to allow water that originated in the U.S.S.R. to flow to the Baltic, i.e., outside the country, where it did the Soviet Union no good.12

It was not until 1984 that the U.S.S.R. Council of Ministers adopted a special resolution or ensuring proper use of water resources at Lake Ladoga and other nearby lakes..": The chief concern was an old pulp and paper mill at. Prio: sk, which had been for decades discharging untreated wastes into the lake. The controversy surrounding the mill bears examination, and will be looked at later along with other economic factors.

As is often the case with environmental issues, writers took up the cause of Ladoga. At the U.S.S.R. Writers. Congress in June 1986, some writers blasted the continuing pollution of the lake. ${ }^{14}$ Petr Proskurin contrasted the

$11_{\text {Romarov, p. } 11 .}$

12 Goldman, spoils..., p. 269 .

13 Pryde, Environmental Management..., p. 82.

${ }^{14}$ See petr proskurin, Literaturnala gazeta, 22 July 1's6: 10: Current Digust of the Soviet Press, 32 (198f), p. 11, and Histisry, Iurii, Literaturnaia gazeta, 2 July 1986: 4; Current Digrst rf thr. Soviet Press, 32 (1986), p. 8 . 
situation with that of Baikal. "We know a great deal about Baikal," he opined,

But what do we know about Lake Ladoga, which is located in the most densely populated region of the country, is the largest reserve of fresh waver in Europe, and provides drinking water to a population many times greater than that which is supplied by Baikal? Yet at the present time Lake Ladoga really is on the brink of biological death, on the brink of the irreversible...."15

In April 1987, the Politburo noted that involved parties to Lake Ladoga pollution were relaxing their attention to the problem. It then announced plans for a profound study of the Lake Ladoga Basin's ecology, preparation of a long-range forecast, and the determination of measures to restore a healthy environment, and instructed party and state agencies to investigate individuals for polluting the lake.16

Problems were numerous. For one thing, environmental management was wanting. Careless practices like over-fishing meant that Lake Ladoga had been virtually fished out by 1972.17 And, as Proskurin pointed out, little attention had been paid to the lake, in contrast to the protests mounted in defense of Lake Baikal. As late as the $1980^{\prime} \mathrm{s}$, Jne textbook, in its section on pollution of rivers and lakes, did not even mention Ladoga. 18

\footnotetext{
${ }^{15}$ Proskurin, p. 10

16"In the Politburo of the C.P.S.U. Central Committee," Pravda, 18 Apr 11 1987: 1; Current Digest of the Soviet Press, 16 (1987), p. 20 .

17 Goldman, spoils..., p. 286

18 plyde, "The future...," p. 561 .
} 
In addition, fertilizer and pesticide runof into the water was high, while the numerous pig farms surrounding the lake contributed to its degradation, mainly through increased phosphorous loads. The bearable phosphorous load of the lake is about 4 thousand tons per year, that is, about half of what is currently entering it. 19 The 2.7 -fold increase in phosphorous concentration since the early $1960 . \mathrm{s}^{20}$ has led to a state of eutrophication, one in which the water becomes rich in nutrients, leading to excessive plant growth, depletion of oxygen, and the killing of $f$ animal life.2l The main sources of the phosphorous are, in descending order, cattle breeding, industry, non-ferrous metallurgy, sewage, fertilizers, and reclamation and soil erosion, 22 about half coming from agriculture. 23

There are 2 closed islands in Lake Ladoga, both in the northwest corner. According to reports, one of the islands is severely contaminated with radiation, while the other has been tho site of tests for biological weapons. 24 The Green Party of St. Petersburg/Leningrad Oblast confirms that there

${ }^{19}$ Ministry of the Environment of Finland, p. 26.

20 Ministry of the Environment of Finland, p. 24.

21 oxford English Dictionary, second edition, (oxford, England: Clarendon Press, 1989).

22 KONSOFIN, pp. 6-7.

23 Ministry of the Environment of Finland, p. 26.

${ }^{24}$ Korhonen, p. C9. 
were Inreed secret radiation laboratories at the lake which dumped their wastes into Ladoga.25

In its 1989 environmental statistics handbook, the U.S.S.R. State committee on Statistics published a list of tactories that dump polluted sewage into the Lake Ladoga Bas1h. Accordirg to the figures, a total of 392 million cubic meters of contaminated sewage were dumped into the basin in 1988, roughly one and a half times the figure from 1985, with most of the waste water originating from enterprises located within the Leningrad Oblast. 26 The coastal irea around Priozersk, for instance, where the cellulose plant was operating, has been rendered lifeless, with ine poisoned zone stretching 100 kilometers into the lake. 27 Moreover, City Council's 1990 ecological map of the Leningrad oblast shows the entire lake as being polluted, not surprising given that many of the oblast's main rivers feeding Ladoga, including the Volkhov, the Sias', the Mor'e, the Pasha, Lle Oiat', the Svir', and tho Burnaia (Vuoksa), are dirty or contaminated by the time their water reaches

25 vladimir A. Gughin, personal interview, 26 June 1992, St. Petersburg, Russia.

${ }^{26}$ Gosudarstvenny i Komitet, p. 136 .

27 Norman Precoda, "Leningrad's Protective Barrier Against Flooding project," Soviet Geugraphy, October 1988, pp. 732-733. 
their mouths. ${ }^{28}$ In all, there are around 500 factories discharging effluent into Lake Ladoga.:0

It is necessary to mention Lake Onega at this point. Although only a few kilometers of the coastline lie within the Leningrad Oblast, the lake affects Ladoga in that the Svir' River brings water, and thus pollutants, from Onega to Lake Ladoga. The main problems concern, first, the pulp and paper mill located at the Bay of Kondopoga on Lake Onega, which produces one-third of the newsprint used in the former Soviet Union. For 30 years, the waste waters from the mill were poured untreated into the Bay. Treatment began just a few years ago. Second, the city of Petrazovodsk dumps the untreated waste of some 270 thousand people directly into the lake. Third, there is intensive water traffic or, Onega, leading to continuous oil spills, with oil concentrations in the lake significantly increasing in the last few decades. Fortunately for Onega, contamination has been limited to bays and littoral (shore) areas, with the main body remaining in good condition. Unfortunately for Ladoga, the water that it receives from Onega contains mostly these very waters. 30

The Gulf of Finland

In many ways, the problems of Lake Ladoga are the problems of the Gulf of Finland, since the lake empties

28"Ekologicheskaia karta Leningradskoi Oblasti." |Erological Map of the Leningrad Oblast, ) Leningrad: Gortekhprogress (Pnginesering center of the Executive Committee of Leningrad rity Counc:11), 19y0.

$29_{\text {KONSOFIN, P. } 6 .}$

30 Ministry of the Environment of Finland, $p .21$. 
directly into the Gulf through the Neva River, with the Neva contributing about 758 of the total river discharges into the Gulf. The Gulf of Finland has a catchment area of 421 thousand square kilometers, covers some 29.5 thousand square kilometers, and has a volume of about 1.1 cubic kilometers. ${ }^{31}$ The Baltic sea is the city's, and, indeed, the country's, marine gateway to the west and is of profound importance. Because of its limited outlets, large surrounding population, and importance as a shipping route, the Baltic Sea has suffered great environmental degradation. In the Gulf of Finland, the most relevant part of the sea where st. Petersburg is concerned, the situation is in a crisis stage. St. Petersburg and the Leningrad Oblast are the chief sources for many pollutants emptying into the Gulf of Finland. Together, for example, they account for point source loads of 608 of the nitrogen and 808 of the phosphorous in the gulf. These figures translate to approximately 288 and 188 respectively of nitrogen and phosphorous making their way into the entire Baltic Sea. In addition, nearly all heavy metals in the Gulf of Finland originate in the city or oblast. 32

In 1971, TASS deplored Baltic pollution but placed the blame on Sweden, Denmark, and other Baltic countries. Yet it did call for international cooperation on cleaning up the

\footnotetext{
31Ministry of the Environment of Finland, pp. 17-18.

32 Ministiy of the Environment of Finland, pp. 21-23.
} 
Sea.33 Then, in 1976, the Council of Ministers passed "On Measures for Stronger Protection of the Baltic Sea Basin Against Pollution." The special resolution called for improvements in the control and disposal of municipal sewage, oil products, pesticides, and other pollutants. ${ }^{34}$

The largest ecological problem for st. Petersburg regarding the Baltic involves the flood protection structure in the Gulf of Finland. The city of St. Petersburg/Leningrad has always had its problems with floods. Being situated barely above sea level and in the Neva Delta at the eastern end of the Gulf of Finland, the city has been plagued by flooding since earliest times, and a solution has been sought to prevent it. But until the $1960^{\prime} \mathrm{s}$, the actual cause for the flooding was not known. It was discovered that it results from low pressure centers as far away as the coast of Iceland. Cyclones from these areas draw up and transport water as they pass over the Baltic Sea, until they weaken. The water then spills out at speeds of up to $60 \mathrm{kilometers}$ per hour, forming the so-called "long wave" that moves eastward through the Gulf of Finland. As the Gulf narrows, the wave speeds up and its crest rises; speeds can reach 100 kilometers per hour. ${ }^{35}$ A long wave, and therefore possible flooding, can now be predicted 5 to 8 hours in advance of the

33Reith Bush, "The Soviet Responge to Environmental Disruptsun," Environmental Deterioration in the Soviet Union and Eastern Eurowt, "sd. Ivan Volgyes, (New York, London: Praeger Publishers, 1974), H. 24.

${ }^{34}$ Pryde, Environmental Management.... p. 88.

${ }^{35}$ Precoda, p. 727. 
onslaught. ${ }^{36}$ It is in this context that the flood protection barrier was conceived.

As part of a general development plan for Leningrad in 1966, feasibility studies for a protective installation began. Five years later, the drafting of a technical design was completed. 37 The general contractors for the project were selected in 1979, with the Ministry of Energy and Electrification and the Ministry of Transport Construction being assigned the duties. ${ }^{38}$ The reason for the latter's involvement stemmed from the need to build, in conjunction with the flood protection barrier, a ring highway around the city of Leningrad. In transit vehicles have to move through the city on their way north or south. The result is congestion and excessive air and noise pollution. A six-lane highway over the dam would divert the flow of traffic around the city. ${ }^{39}$ Besides the Ministry of Energy and Electrification, the Academy of Sciences, the Ministry of Land Reclamation and water Management, and other concerned bodies were to carry out research "...with the aim of devising measures to protect and upgrade the Lake Ladoga-Neva

\footnotetext{
36 . Zakharko and $y$. Mikhailov, "A City's Reliable Shield," lzvestiia, 21 August 1979: 3; Current Digest of the Soviet Press, 34 (1979), p. 8 .

${ }^{37}$ Zakharko and Mikhailov, p. 8.

38"V TsR RPSS i Sovete Ministrov SSSR," [In the C.P.S.U. Centra] Committee and the U.S.S.R. Council of Ministers,] Pravda, 19 August 1979 , p. 1 .

${ }^{39}$ Precoda, Pp. 728-729.
} 
River-Neva Bay water system." 40 Although all seems to have proceeded fairly rapidly from the center, Barbara Jancar claims that there was much opposition to the project from various central agencies, and the city decided to pursue the project at its own expense. However, in December 1982, then Chair of the Leningrad Party, Grigorii Romanov, apparently demonstrating his political ascendancy, announced that Andropov gave his support to the plan.41

with such a projest there were, needless to say, concerns regarding the environmental impact. Chief among them was the question of water quality on the closed of $f$ portion of the Neva Inlet; without the natural currents, tides, and even flooding, water could stagnate there, especially given that that area served as a repository for sewage and waste, both directly from the city and indirectly through the Neva. And, according to S. Kuraiev, chief design engineer of the project, "In the drafting of project 'Sea Shield,' [nickname of the flood protection project,] maximum attention was paid first and foremost to protecting the environment and evaluating the long-range hydrologic cycle and the sanitary condition of the Neva Inlet's waters." He added this caveat, however: "The sanitary condition of the Neva Inlet will be determined not by the protective installations but by the completeness and quality of sewage

40 "V TsK KPSS...." p. 1 .

41 Barbara Jancar, Environmental Management in the Soviot Unson and Yugoslavia: Structure and Regulation in Federal Communst Statrs. (Durham: Duke University Press, 1987), p. 183. 
treatment." This, he claimed, was receiving great attention. 42 Indeed, as a fundamental condition for undertaking the construction of the dam and ring highway, involved ministries stipulated that construction of waste treatment facilities would have priority. ${ }^{43}$

Environmental problems seemingly associated with the dam construction began to appear almost immediately after work began. In the summer of 1986, beaches were closed along the northern shore because of the foul water in the inlet. 44 Studies subsequently showed that apertures in the wister openings of the dike had to be cleaned. The apertures were cleaned in the fall, improving water flow, 45 but questions remained concerning water quality, particularly along the northern shore.

Meanwhile, dike opponents claimed to have been hampered by lack of access to information. In November 1986, they allege, a discussion of the dam included much criticism by leading scientists who cited worsening pollution and the need to proceed with the construction of water treatment facilities. The proceedings of the meeting, however, went unpublished and were not made available to Leningrad's

\footnotetext{
$42 \mathrm{~s}$. Kuraiev, "Please Tell Me About This 'Shield Against Floods," Pravda, 21 May 1984: 7; Current Digest of the Soviet Press, 20 (1984), p. 23.

43 Precoda, pp. $728-729$.

44D. Likhachev, D. Granin, M. Dudin, and A. Liverovskii, "A gde zashchita ot damby?" [But Where Is Protection From the Dam?] Izvestiia, 11 January 1987 , p 3 .

4 Precosa, p. 731.
} 
scientific community. On the contrary, at a subsequent press conference held by construction administrators, it was claimed that all was proceeding well.46

In response to the perceived ecological problems, a commission headed by V. A. Rumiantsev of the Academy of Sciences' Limnological Institute, and consisting of members of the U.S.S.R. Academy Sciences and various economic ministries, undertook a study of the situation in 1988-1989. The commission concluded that, although the dam was not responsible for all of the ecological problems concerning the Neva Inlet, it did seem to have aggravated the situation. There was a possibility that stagnant zone.; of water could form directly behind the structure. How ver, the commission argued that charges of increased water alinization and disruption of water currents and fish $\mathbf{n}$ !ration were unfounded. In the end, only one member of the commission believed construction should be halted. 47

Apparently unsatisfied with the first commission's findings, the Presidium of the U.S.S.R. Acadeny of Sciences commissioned another study, headed by Academy of Sciences Member and Vice-Chair of the U.S.S.R. Supreme Soviet's Joint Committee on Questions of Ecology and the Rational Use of Natural Resources, A. Iablokov, which issued its findings in June 1990. Unlike the previous commission, it concluded that

\footnotetext{
46. Likhachev, et al, "A gde...," p. 3 .

47 Ia. Strugach, "Fault and Misfortune," Leningradskald pravad, 21 April 1989: 2; Current Digest of the Sovict Press, 19 (1984), p. 23.
} 
the dam was the chief cause of the environmental disaster in the Neva Inlet and eastern part of the Gulf of Finland, and recommended either tearing down the dike or taking measures to increase its permeability. In addition, the commission called for legal action against responsible parties for the waste of money and the dangerous design of the dam.48

Following the report, the Ltningrad City Soviet adopted a decision in October 1990 to stop all construction on the dam as the first step toward determining future plans. It based its decision on findings from its Ecological Commission, which cited the growing ecological crisis in the Neva Inlet. ${ }^{49}$

Construction continued, however, despite City Council's decision. According to Academic D. Likhachev, an opponent to the dam, the construction lobby undermined Lensoviet's decision, obtaining additional funding for completion of the dam according to the original plan. 50

Next, according to Iablokov, G. Marchuk, President of the U.S.S.R. Academy of Sciences, added his own amendments to the June 1990 report, and, in a letter to the Chair of the Council of Ministers, recommended that yet another commission

\footnotetext{
48V. Nevelskii and K. Smirnov, "Leningradskaia damba: chas pik," [The Leningrad Dike: The Moment of Truth,] Izvestila, 28 June $1990, p$. 2 .

49 Vladimir Nevelskii, "Stroitel'stvo damby prostanovit'," [Dike Construction to be Halted, I Izvestila, 17 October 1990, p. 2.

Sob. Likhachev, et al, "Damba stroitsia vopreki trebovaniiam Leningradtsev," [Dike Being Built Contrary to Demands of Leningraders,] Irvest11a, I June 1991, P. 3.
} 
be formed. The Council of Ministers agreed to the request. and an international review was conducted under the leadership of the designers of the dike. As Iablokov laments, "[t]he command-administrative system would prevail," as only party leaders and those connected with construction sat on the panel.51 This commission, which cost $\$ 400,000$ U.S., concluded the dam was safe and : construction had to be completed, and broadcasted the findings on national television in December 1990. Yet, secrecy surrounded the commission's actual findings, and it is not even known which officials made the decision to continue the project. 32

Despite City Council's decision in 1990 to hold the project in abeyance and to declare an international competition for its reconstruction, Council Member vergei Pomagaev claims that the city Council has changed its opinion, albeit unofficially, by slowing down the processes of preparing the competition and implementing previous decisions. He claims that construction of the dam continues" and that the commission assigned the responsibility of

51. Iablokov, A. Monin, Iu. Polyansky, and S. Zalygin, "Dces the: President Need the Scientists? Why G. I. Marchuk, President of the U.S.S.R. Academy of Sciences, Disagrees with the Conclusions of the Expert Scientific Review of the Leningrad Dike," Izvestila, 7 August 1990: 3: Current Digest of the Soviet Press, 32 (1990), p. 24.

52Likhachev, et al, "Dike Being Built...," p. 26 .

${ }^{53}$ The work on the northern section, connecting Gorskaia on the mainland with Rotlin Island (Rronshtadt), was supposedly completed in 1984. However, I visited kronshtadt the sumer of $199 \mathrm{Z}$ and drove across the northern dike. The actual : onnection is finisherd. Still, work there continues, with scaffolding and heavy equipment clearly in evidence. The road itgelf is not even completely paved, and much dothis is litters the area. 
organizing the competition and subsezuent work was not formed for two years. It seems, as well, that the purpose of the competition has changed to a softer position; instead of a complete decommissioning or destruction of the dam, city council is now reducing the scope of reform, looking simply at refining the construction. 54

Oddly enough, part of the problem appears to be that cessation of construction would actually cost the city money. Although funding for the dam project is coming from the city budget, and thus halting construction would appear to save money, the funds ultimately came from Moscow and were allocated for the very purpose of building the dam. If the city doesn't use the money for the construction, it must pay a penalty to Moscow, apparently in the form of higher taxes.55

Although the environmental state of the Neva Bay is poor, only some of the degradation can be directly attributable to the dike. Studies indicate that the environmental impacts of the barrier are thus: first, the general drift and circulation of waters between the inlet and the gulf have been disrupted. This has created a 400 square kilometer area of stagnant warer, a "sewage settling area." Along the northern shore, in particular, a stagnant zone has formed. Second, the Neva Inlet is experiencing a large build-up of sand and silt, which previously were washed away

\footnotetext{
${ }^{54}$ Sergei Pomagaev, personal interviews, 27 May and 6 June 1992, st. Petersburg, Russia.

${ }^{55}$ Pomagaev.
} 
by floodwaters. Third, fishing catches in the Inlet have fallen off dramatically. Also, the barrier's effect on ice flows is uncertain, and an accumulation on the east side of the dam could impede shipping. 56 In addition, water salinity in the Neva Bay has been reduced. 57

So, despite the continual assurances from proconstruction forces that ecological problems would be addressed, severe problems arose. Upon closer examination, the reasons become clear. According to Leningradskaia pravda, "Surprisingly few studies were done before construction of the dike system bagan, and those that were completed were generally fragmentary and uncoordinated." Chair of the Leningrad city Soviet at the time, Anatolii Sobchak, who later became Mayor of the city, stated that, initially, water treatment facilities were to precede dam construction, then plans were modified so the two would proceed concurrently but that of the treatment facilities at a quicker pace, and then, finally, the treatment facilities were forgotten aitogether. 59

There were also questionable construction practices. Problems were thought to have arisen because builciers did not

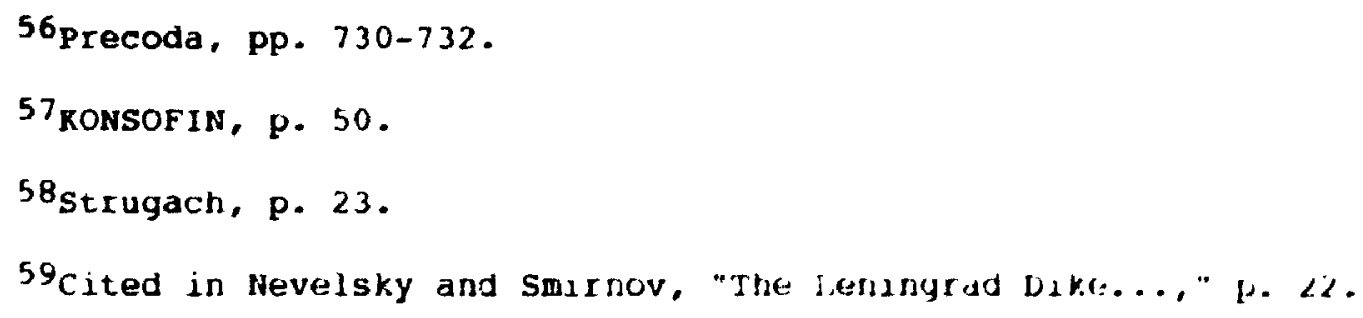


adhere to the construction scheduleto nor to the construction procedures.": In addition, the project was pushed through without input from below. Writers and academics opposed to the dike charged that both the design process and the start: of construction took place in secret. They continue:

Not the slightest bit of scientific discussion of the project was permitted, despite specialists' protests. The ${ }^{\circ}$ were alternative proposals for protecting Leningrad from floods, but they were never properly examined. The decisions were made in an openly arbitrary fashion. Those who disagreed were removed. 62

Waste water treatment, a precondition for clean water in Nevskii Bay, was severely lagging in the area. The 12 th Five-Year-Plan, covering 1986-90, emphasized treatment of water resources. For St. Petersburg, this money for treatment facilities and industrial water recirculation and treatment appears to have significantly decreased the organic and inorganic wastes ilowing into the Gujf of Finland. Still, the plan's conservation goals were not met. 63 According to an article in Soviet Geography in 1988 , "...construction of treatment facilities is two years behind schedule and the gap is widening." 64 The result is that much

$60_{A}$. Shevtsov, "Concerning the Building of the Leningrad Dike," Fkonomicheskala qazeta, $48(1986)$ : 10; Current Digest of the Soviet press, b2 (1986), p. 13.

${ }^{61}$ A. Ezhelev, "Eshche raz o dambe," [Once Again Nbout the Dam,] Irvestia, 22 February 1987, p. 6.

62 likliachev, et al, "A gde...," p. 3 .

63 Exact 1 a, sects on 6.1 .

Hirecodi, pF. $730-131$. 
effluent is dircharged without treatment. Recent figures show that over 378 of the city's discharge into natural recipients is untreated.65 And not only is construction of waste treatment facilities lagging, but also those being built are not capable of providing full treatment. th

The dam's current status is thus: according to a letter from Presidential Advisor Iablokov, President Yeltsin, after consultations with the Mayor of St. Petersburg and the Ministry of Ecology and Nature-Use of the Russian Federation, instructed E. Gaidar in April 1992 to prepare a decree resolving the dike issue. ${ }^{67}$ In May, Gaidar's office issued a declaration on the subject, outlining the following steps:

To accept a proposal from the executive offices of St. Petersburg, submitted with the agreement of other concerned bodies of the Russian Federation, to carry out in 1992 a competition for improving the ecological situation in the Neva and the Neva Bay, and improving the dam structure. In order to carry out the competition, 500 thousand rubles originally set aside for construction is to be made availatıle The Mayor's Office is to work out the terms of the? competition, including an estimate of expenses for carrying it out. The Mayor is further instructed to submit to the Russian Federation in the first quarter of 1993 the final

\footnotetext{
${ }^{65}$ RONSOFIN, P. 27.

${ }^{66}$ precoda, pp. $730-731$.

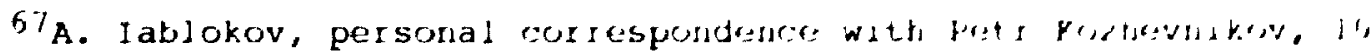
June 1992 .
} 
terms of the competition, with suggestions on how to improve the ecological situation in question and how to protect the city from flooding

Various involved Russian ministries, the Russian Academy of Sciences, and the Mayor's office are to provide help to competition participants by granting necessary materials, acquainting them with the situation, etc. 68

The Air

St. Petersburg has been spared the air pollution of similarly sized cities elsewhere in the world or even of smaller Soviet cities with high concentrations of, for example, ferrous or non-ferrous metal industries. Indeed, Leningrad did not even make the list in a study in Trud in 1989 citing the 68 Soviet cities with the worst air pollution in the country.69 In Mote's $1970^{\circ}$ s study mentioned earlier, he cites the potential problem areas for air pollution in St. Petersburg as transportation (cars, trucks, buses), power stations, and the construction industry, although no dangerous levels of particular air pollutants were noted. 70 There are 20 thousand natural gas vehicles in the city, 71

68.0 provedenii vybora konkursa proektov i programm po ozdornvleniiu ekologicheskoi obstanovki v Nevskoi gube i korrektirovke proekta stioltel'stva sooruzhenii zashchity g. Sankt-Peterburga ot navodnenil," fon the Holding of a competition for Projects and Programs for Improving the Ecological Situation in Nevskii Bay and for Correcting the Construction project to Protect St. Petersburg from Floods, ] Resolution of the Government of the Russian Federation, 18 May 1992.

${ }^{69}$ D. J. Peterson, "The State of the Environment: The Air," Report on the I".s.S.R., 2 March 1990, p. 9.

\footnotetext{
70 Mote, "The Geogr aphy...." p. 23.

:Ministiy of the Environment of Finland, p. 37.
} 
although as of 1991 only two filling stations for natural gas vehicles existed, 72 while 708 of the city's power stations are now burning natural gas, which helps explain the relatively good air quality. ${ }^{73}$ Finally, only unleaded fuel is reportedly delivered to the city, reduciny lead emissions.74

That is not to say that atmospheric pollution is not a problem; a 1990 report shows that total emissions in the city amount to 191 thousand tons per year, including the following: 49 thousand tons per year of solids; 57 thousand tons per year of sulfur dioxide; 42 thousand tons per year of nitrogen oxides; and 16 thousand tons per year of hydrocarbons. ${ }^{75}$ The region's conversion rate of power plants to natural gas is not as good as the city's, amounting to only 178.76 Emissions from the oblast total somewhat more than 660 thousand tons per year. 77 In recent years, there has been some stabilization of atmospheric pollutants, namely dust and nitric oxides, while others continue to increase, like carbon oxides and phenol. ${ }^{78}$

\footnotetext{
72Ekologicheskaia Kommissila, [Ecological Commssion, ] "Usnovnyr: shagi $v$ oblasti okhrany okruzhaiushchei sredy Leningrada," [Fundament a] steps for Protection of Nature in the Leningrad oblast, l (preliminary report, ) 1991, section 6.1.1.

$73_{M}$ nistry of the Environment of Finland, pp. 1-i1, 3.

${ }^{74}$ Ministry of the Environment of Finland, p. $3 \%$

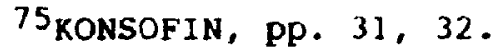

${ }^{76}$ Ministry of the Environment of Finland, pp. 1-11.

77 KONSOFIN, p. 30.

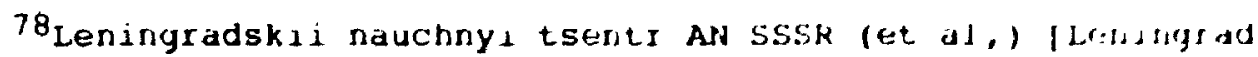
Science center of the U.S.S.R. Academy of Scienres, et al.
} 
While atmospheric pollution may be relatively mild, secondary pollution from the atmosphere, that is, acid rain, does constitute a problem area. Although the country itself is not subjected to great amounts of acid rain and snow, the Leningrad Oblast is one of the few areas to record significant acidity levels. ${ }^{9}$ Heavy metals and many organic toxins are deposited in the Gulf of Finland more through the atmosphere than from rivers, runoff, or waste waters. 80

\section{THE BCOMOMIC SETTING}

The state of the environment is so entwined with that of the economy that a healthy environment cannot be maintained under adverse economic conditions. According to a report on nature-use in Leningrad, current environmental conditions there are mainly the result of the economic system, its principles, tenets, and goals. ${ }^{81}$ The economy of St. Petersburg, like that of the rest of the country, is weak. However, in addition to the same troubles plaguing other areas, St. Petersburg is beset by its own special economic problems.

\section{Industry}

The Leningrad region has one of the country's highest rates of economic development, with nearly 2,000 enterprises

"Kontseptsi ia razvitiia prirodopol'zovaniia v Leningradskom regione," (Conception of Nature-use Development in the Leningrad Region, ] (preliminary report,) Leningrad: 1991, p. 11 .

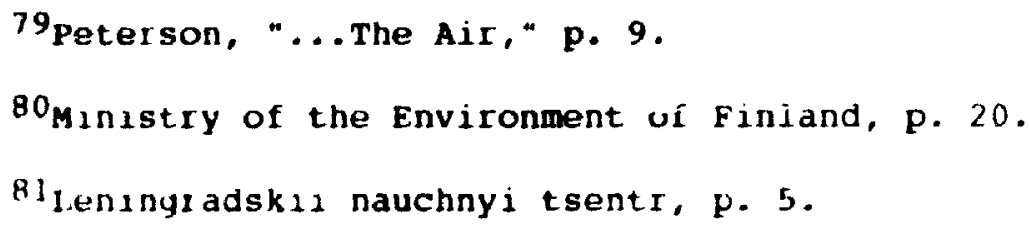


located there. ${ }^{82}$ The basic industries of the area include machinery and machine-tool-building, ship-building, chemical, fuel, pulp and paper, and wood-working. ${ }^{83}$ Unfortunately for the environment, the cornerstone of its manufacturing base has been heavy industry. Although many of its political leaders, including $\mathrm{z}$ inoviev and $\mathrm{zhdanov}$, attempted to develop Leningrad as a center for the consumer industry, the economic plan under Stalin dictated otherwise and, especially since the 1940's, the city became oriented toward heavy industry. With its skilled labor force and scientific base, the city's share of light and consumer industries declined under the leadership of Kozlov in the 1950's and Romanov in the 1970's, with the economic strategy favoring machine construction, shipbuilding, and other heavy industry, particularly the military sector.

In part due to environmental degradation, there was a shift in direction in the general plan of 1986 . Industrial and scientific facilities were to be moved to surrounding suburban zones, resulting in spatial, industrial, and population expansions of the city. Because of the regional integration, the constituent parts of the city and region can not be isolated from each other. Therefore, in considering environmental problems of the region, they must, as much as possible, be considered together. ${ }^{84}$

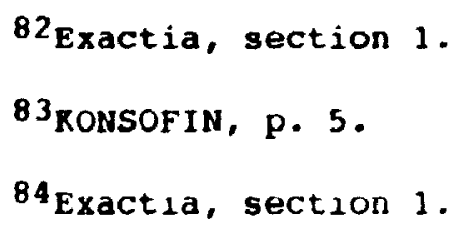


Because of lack of foresight in the original plans for the city's industrial sector, much of the structure and distribution of productive forces are not compatible with the quality and quantity of natural and labor resources in the area. Many branches that previously focused on exploitation of local resources are now fully or mostly operating on imported raw materials, due to exhaustion of local resources. Among them are the pulp and paper industry, the "Fosforit" works, and plants in Pikalevo. Other enterprises have been dependent on imported raw materials from the very beginning of operation, among them those in the ferrous metallurgy, pig-iron, chemistry, and petroleum industries.85

Additionally, having pursued a purely quantitative approach to water resources, planners concentrated waterconsuming industries in Leningrad. The majority of agricultural and industrial development has been located directly at water resources or within their protection zones. 86

Because of its great size and role in the region's economy, the military industry warrants scrutiny. Leningrad was a hub of the military-industrial complex, consuming about one-fifth of the Soviet research and development budget, with the military share of total production in the city reaching

\footnotetext{
${ }^{85}$ Leningradskii nauchnyi tsentr, p. 6.

${ }^{86}$ Leningradskıi nauchnyi tsentr, pp. 6-7.
} 
60 to 708.87 The industry is a giant consumer of resources ${ }^{34}$ and, partly due to the notorious secrecy, it has been subjected to few ecological controls, checks, or monitoring. ${ }^{4}$ For example, following the International convention on the Prevention of Pollution in the Baltic, which was signed in March 1974, Swedish ships made spot checks for contaminants in the Baltic Sea. They found large concentrations of P.C.B.'s, particularly near the mouth of the Neman and other rivers in the U.S.S.R. The Swedes made several protests to the Soviets to take proper measures, but, in the view of Boris Komarov, Soviet experts honestly believed that P.C.B.'s were not in use in the Soviet Union, and responded to that effect. In 1976, however, a worker at the Institute for Applied Geophysics of the Hydrometeorological Service made some tests, revealing that literally evt:y body of water, [including Lake Ladoga,] contained P.C.B.'s. The search for their source revealed that the military had been producing P.C.B.'s since the $1950^{\prime}$ s. Precautionary measures had rot been taken in the production of the P.C.B.'s, and health experts were not notified, so they could not take action or notify foreign bodies. 90

The arbitrary price-setting mentioned earlier pervaded the military industry in particular, whose branches set

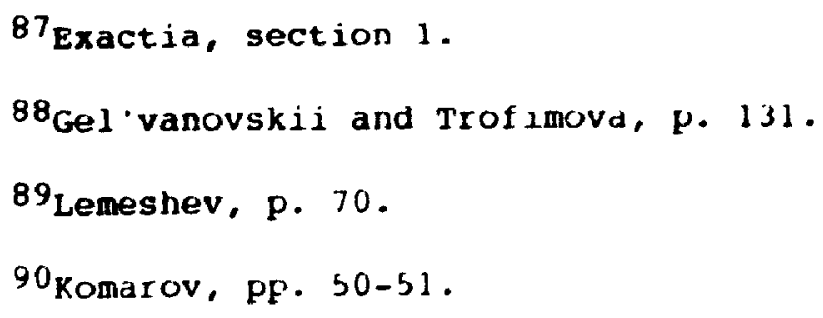


artificially low prices for raw materials, metal, and energy. To make matters worse, true military spending figures have been concealed, obfuscating per unit costs of weapons, making them appear to be relatively cheap to produce. ${ }^{91}$ Such artificial prices indirectly play havoc on the environment, as energy and metal-intensive production thrives and conversion to civilian production is discouraged because the 'cheap' military hardware can be sold abroad. Plants that would otherwise be closed for financial reasons, therefore, can be kept open and continue heavily polluting. By the end of 1991, only 12 of 5 thousand military plants in the country had been shut down. 92

The area's water reserves, in conjunction with abundant forest resources in the area, led to thriving and heavily polluting timber, wood processing, and pulp and paper industries. Environmentally, the industries are large consumers of water for use in the production process; logs are of ten transported via waterways, a particularly ecologically damaging method; felled trees leave barren land that is subject to erosion; and the pulp industry discharges large amounts of effluents into local bodies of water. In fact, the wood-processing and pulp and paper industries are

91 Yevgeny Aleksandrov and Vyacheslav Rolbin, "The Country's Economy is Buried Under Piles of Weapons," Izvestiia, 16 June 1992: 3; Curtent Digest of the Soviet Press, 24 (1992), p. 18.

${ }^{92}$ Aleksandrov and kolbin, p. 18. 
responsible for 428 of effluent discharged into the area's waterways.93

An article in Literaturnaia gazeta in 1965 pointed out some of the problems of the forest industry. Instead of using the stumps, boughs, and crowns of trees remaining after the main portions of trees were cut, the lumber industry disposed of them on-site. This practice was common in the Leningrad Oblast's forests, as confirmed by observations along the Firnish border. And the scraps burnt often amounted to fairly large chunks of wood. 94 Kathleen Braden confirms another aspect of faulty forest practices. She says that up to the 1970 's, overcutting was widespread, with a decrease especially in conifer stock. In the Baltic region, annual allowable cuts were regularly exceeded. ${ }^{45}$

The pulp and paper industry is described by Russian economist A. G. Aganbegian as "...occupying first place among the sources of water pollution." 96 In the Leningrad oblast. the pulp and paper industry is chiefly responsible for sulfur, phenol, and organic pollutants, affecting the oxygen balance of various bodies of water, especially Lake Ladoga,

92 KONSOFIN, P. 18 .

94 Leonid Leonov, "Concerning Large Chips of Wood," Literaturnalat gazeta, 30 March 1965: 2; Current Digest of the Soviet Press, 20 (1965), p. 13 .

95Kathleen E. Braden, "Environmental Issues in Sovjet rorest Management," Soviet Geography. June 1988, p. 601.

${ }^{96}$ Quoted in Mildred Turnbull, Soviet Environmental pollcles and Practices: The Most Critical Investment, (Hants, England and Brookfield, Vermont: Dartmouth Publishing Company, 14\%11, $2.6 \%$ 
increasing methane levels, and accelerating the spread of nutrients in sediment, with the last of these having the most far-reaching effects. 97 Moreover, the industry is terribly inefficient: in 1985, Soviet mills consumed 5.2 times the amount of wood as U.S. mills for each ton of paper and cardboard produced. ${ }^{98}$

According to the University of Glasgow's Mildred Turnbull, "[t]he foremost reason that the pulp and paper industry has problems with productivity and environmental protection is its dependence on obsolete technologies. The situation has led to an extraordinary level of pollution." 99 For instance, the Siasstroi Pulp and Paper Combine, located just southeast of Ladoga, was founded in 1928 and is still using the original sulfite cooker. 100 To give a further idea of the antiquity of the industry, Izvestila reported in 1988 that of the 157 enterprises comprising the pulp and paper industry, 65 were either built after or had undergone reconstruction and technical overhauls since 1960. The remaining 92 facilities, [598 of the total,] date from the beginning of the century or before. ${ }^{101}$

97Ministry of the Environment of Finland, p. 26.

${ }^{98}$ Turnbul1, p. 81 .

${ }^{99}$ Turnbull, pp. 69-70.

100 ministry of the Environmert of Finland, p. 39.

101 lu. Grin'ko, "Bumazhnyi bum co znakom 'mınus, " [Paper Boom with a Minus Sign, J Izvestila, 5 February 1988, p. 1. 
The industry suffers from lack of access to waste-free or waste-reducing technologies, which has been due, in part, to ministerial insistence on the use of domestic technologies only. This insistence, in turn, is fraught with problems because of the unresponsiveness of the machine-building industry, which, in Turnbull's opinion, "...simply does not manufacture pollution control equipment in the quantities, range, and qualities sufficient to mret the competing demands from a diverse spectrum of industrial enterprises."102 The fact that technology in the industry is lagging fits in with the overall picture of industrial investment in St. Petersburg, which for years has been below the rate required for mere maintenance of machinery.103

Although pulp and paper industry officials are wont to blame technological and mechanical shortcomings on the machine-building industry, it cannot be said that the latter is simply unwilling to cooperate; it has its own internal problems. For instance, there are not enough qualified engineers to take on the capital repair and construction needs of the pulp and paper industry. In addition, not only are domestic designs inferior to foreign technology, but the actual fabrication of the equipment is flawed, further decreasing its useiulness. Next, the technology for the pulp and paper industry is designed on a piecemeal basis, impeding the machine-building industry from mounting a consistent and

102 Turnbull, pp. 67-68.

$103_{\text {Exactia, sectior } 1 .}$ 
long-term production scheme. Finally, the quality and quantity of chemicals produced by the chemical industry are wanting: these chemicals very much determine how wel: the technology will perform. 104

The Priozersk Pulp Mill on Lake Ladoga deserves special mention because of its sheer size, its hand in polluting the lake, and the battle to shut it down, culminating in the closure of pulp operations in 1987.

The main actor in the drama was Iu. S. Zanin, Priozersk's chief of sanitation services. He had twice closed the Priozersk mill for sanitation violations, but each time it had been reopened, apparently with his consent. Finally, in early 1987, he closed the mill for a third time. This time, lines were drawn and a battle ensued. The mill's director, A. V. Barkalov, sent a telegram to Moscow, citing test results from the mill's laboratory, showing that no dangerous discharges were present, while Deputy Minister of the Timber, Pulp and Pape- and Lumber Industry, G. Pronin, claimed he had drunk water directly from the lake. As central authorities prepared to reopen the mill, Leningrad Party and Soviet leaders, apparently concerned over their drinking water supply, unexpectedly supported the plant's closure. Pronin and other officials issued threats, and hinted that zanin was headed for jail, and the former Minister of Public Health gave the go-ahead to reopen the mill. In the meantime, Barkalov argued that, 104Turnbul1, pp. 77-79. 
personally, he had been put in the position of Plant Director to produce cellulose, and that is what he intended to do.

Furthermore, he claimed that not he, but his bosses, would be held responsible if actions were taken against the mill, that he would simply be given another enterprise, and he doubted that such an important mill could actually be shut down; the Priozersk mill produced one-fifth of the Soviet Union's viscose cellulose.

Even as rumors circulated through the mill that he would be fired, Zanin continued his attacks. He had been accumulating data over the last 20 years and refuted the mill's findings. As he continued his crusade, journalists and the public became more and more concerned.

Finally, in April, the Ministry of the Timber, Pulp and Paper and Lumber Industry decided to shut down cellulose operations at the mill in favor of the more ecologically clean furniture production. But on the very day the order was to take effect, a group of the mill's workers shrwed up at ministry offices in Moscow and convinced the ministry to reopen the mill on 1 May.

The workers, it seems, were frightened at the prospect of losing their jobs and apartments. Some had been taken to a particularly backward enterprise to see what might await them. At one point, workers were given xerox hanuouts telling them that pollutants in the lake were good for them. Finally, however, Zanin spoke to the workers and convincedt 
them of the need to think of their health, and the mill

finally closed its pulp and paper production.105

In May, the C.P.S.U. Central Committee placed the blame for the Priozersk situation on the leadership of the Ministry of the Timber, Pulp-and-Paper, and Lumber Industry. It issued reprimands to the Minister, M. I. Busygin, for not acting to end effluents from the mill, as well as to Iu. G. Losev, First Deputy Minister of Construction in the Northern and Western Regions, for inadequate construction of water protection facilities at the mill.106 When subjected to legal pressure, the mill's laboratory recanted its previous stance, issuing figures that exceeded even those of zanin.107

In the end, several involved figures were prosecuted. Former plant airector Brega, former chief engineer Piarevskil, and former shop head zhuravlev were all convicted for their parts in polluting Ladoga. 108

\section{Agriculture}

There are more thin a few environmental problem areas with regard to regional agriculture practices. First is the destruction of natural ecosystems as a result of land reclamation for agricultural purposes. Next is the large

103 G. Razin, "In the Murky Mirror of Lake Ladoga," Romsomolskaia Mavda, 29 May 1987: 2: Current Digest of the Soviet Press, 23 (1987), pp. $11,23$.

106 "In the C.P.S.u. Central committee," Izvestila, 29 may 1987, p. 1; (urrent Digest of the Soviet Press, 23 (1987), pp. 10-11.

107 Razin, p. 11 .

108"lisloda I my: v 'rokurature Soiuza 55R," INature and Us: In the l1.S.S.R. Prosecut's 's offict, ] Izvest11a, 26 November 1987, p. 6 . 
amounts of nutrients and organic wastes discharged into ambient soil and water. There are also problems resulting from defective fertilization methods, transport losses, etc.

Cattle and pig farms surrounding Lake Ladoga present serious pollution problems. Because of the technology used at the six pig farms in the region, pig waste is liquid, presenting a dilemma on how to process it. The waste load from the piggeries is equivalent to that of one and a half million people. Over half the waste from the pig farms is treated insufficiently or not at all. The wastes are stored in open-air earthen dams, whose leaking causes water and soil contamination. Under these circumstances, bacteria and viruses can easily spread. In this case, ammonia evaporation contaminates the air. The location and poor construction of the dams makes them "ecological time bombs" that threaten not only locals but the entire Gid! of Finland.10\% In 1976, an accident at the Novyi svet farm, in which a dam collapsed, allowed pig wastes to enter a local river, killing of fish.12:

Pesticide use in the Leningrad area is relatively high, with an average of $4.3 \mathrm{~kg}$. per hectare, with some areas applying as much as $20.3 \mathrm{~kg}$. per hectare, ${ }^{111}$ and their use in the region is rising. In the Ladoga Basin, pesticide usw exceeds former soviet norms by a factor of about two, and in

${ }^{109}$ Munistry of the Environment of Finland, whe iis, 30, $\$ 1-34$.

110 Minastry of the Environment of findere, p. HA.

111 Leringiadski naurhny tsont, $1, \mu$. 
the Baltic sea basin zones, the figure is even higher.112 The pesticides employed break down slowly and thus are more apt to work their way into bodios of water.11? Although the causal factors involved are, without a doubt, complex, Komarov cites medical studies that have shown that peasants in the area were getting cancer as often as mine workers. Pesticides, which are often sprayed from airplanes, are inhaled in large quantities ay nearby rural populations, 114 which could help explain the statistics.

The record on fertilizer use is similar. Estimates in some water catchment areas of St. Petersburg show 358 of discharges into water reservoirs attributable to storage losses and $10 \%$ due to improper fertilization methods.115 A new packaging system underwent testing at a regional center, and losses proved to be practically nil. Unfortunately, shortages of some essential components prevent implementation of the new methods.11f

Effects on consumers of the agricultural products are also worrisome. One third of all produce tested in Leningrad in 1987 contained levels of pesticides deemed hazardous to

112 RONSOFIN, p. 24.

11.j. Shchepotkın, "Nature Presents a Bill," Izvestila, 15 September 1981: 2; Current Digest of the Soviet Press, 36 (1587), p. 20.

114 Koma rov, pp. 43-44.

11 'KONSOFIN, p. 23.

116 KUNSOFIN, p. 25 
health, 117 yet regulating agricultural products is diffirult. For one thing, produce may be grown on any given plot of land, even a contaminated one, and there is no way to monitor improper chemical use. Also, foodstuffs can be in short supply and as such are at a premium, while the pell-mell nature of sales, with produce being sold anywere and everywhere, defies regulation. 118

Sewage that has been cleaned of dangerous wastes can be applied to specific crops. This is becoming a popular form of fertilization throughout the country. But because of soil conditions around the city, simple irrigation with municipal effluent cannot be used. Marshall Goldman claims that farmers in Leningrad therefore employed dried solid waste from the water treatment plant.11: Unfortunately, sludge treated at water treatment facilities has a high concentration of heavy metals and therefore cannot be used for agriculture, necessitating dumping it at a special sitelon and wasting a potential source of fertilizer.

\section{Energy, Transport, and Waste Disposal}

$117 \mathrm{D}$. J. Peterson, "The state of the Environment: The I,nrid," Report on the U.S.S.R., 1 June 1990, P. 12.

118 Ekologlcheskala Kommissila, section s.4.

119 Goldman, spo11s..., pp. $282-283$.

120 Ministry of the Environment of Findand, pp. 24, 61. This wrull seem to contradict Goldman's observation that. hre dry sludge: is empiryord as fertilizer. Because it is a much older source, perhape roldman's observation is simply dated, or can be attributed to, unoffucial is surreptitious practices. 
In 1973, the first unit of the Leningrad Atomic Power Station went into operation. The station is located in Sosnovyi Bor, some 80 kilometers from St. Petersburg. The placement of the reactor is questinnable. Like many others in the country, it was built very close to a major population center, but in this case the question arises of the need for the plant at all. According to Iu. Bublik, a fuel and energy expert, the Leningrad area already had a great surplus of electric power when the station was built. His point is bolstered by the fact that power transmission lines from the plant were extended into other regions.121

The reactor is an R.B.M.K. type, the same kind as that used in Chernobyl, and produces 1,000 megawatts of power.122 Leningrad received a dose of radiation from the Chernobyl accident, 123 but use of R.B.M.K. reactors has implications for St. Petersburg beyond that. On 24 March 1992, the number 3 power generating unit at the Leningrad Atomic Power Station in Sosnovyi Bor underwent an emergency shutdown. The plant suffered a steam leak, which spewed a total of some 3 thousand curies into the atmosphere.124 While the release of

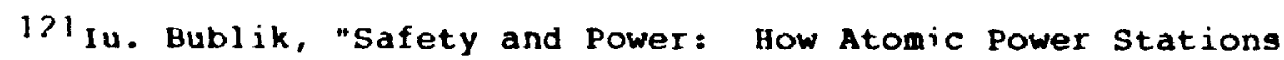
Should Develop," Sovetskaia Rossiia, 30 April 1987: 3; Current Digest of the Soviet press, 17 (1987), p. 5.

122 Pryde, Environmental Management..., p. 40.

123 Murray Feshbach, "Global Environmental Security and the PostCommunist Region," presentation at conference "Environmental security After Communism," ottawa, Ontario, 26 february 1993.

124 "Situation Returns to Normal, But Questions Remain," Izvest11a, 24 March 1992: 2; Current Digest of the Soviet Press, 12 (1992), p. 32 . 
2 thousand curies/day constitutes an emergency situation, the night of the accident the rate of release was only around 1300 curies/day. The plant releases between 160 and 200 curies/day under normal operating conditions.125 The incident was, according to the International Atomic Energy Agency, initially thought to be a class 3 accident, but was later downgraded to class 2 , as opposed to the class 7 accident at Chernoby 1.126

Although concerns had been voiced prior to as well as after the accident, criticism at the time was muted by what was considered to be a fairly quick and open revelation of the circumstances, at least in contrast to the past, with at least one newspaper having been able to interview an engineer at the plant the same day that the accident occurred.1:' Nonetheless, except for one team from the central television station, "rone of the numerous reporters on hand shortly following the incident was allowed to inspect the inside of block number 3 or even to meet with the director of the power plant, and only specific officials would talk to reporters.lik Following the accident, a low-key protest against the reactor was organized. According to Swedish journalist Leif Svenson, in the summer a tent city of sorts sprang up very

125D. Grigor'ev, "Zhirnalisty okruzhl] i reaktor," IJournallsts Encircled the Reactor, ] Vechernii Peterburg, 25 March 1952, p. 1.

$126_{\mathrm{Grigor}}$ ev, p. 1 .

127 A. Volodin, "Ch. P. na atomos," IExtraordinary tevente at Atoma" Station, ] Vechernil Peterburg, 24 March 1992, 1. 1.

$128 \mathrm{Gr} \perp$ gor $\mathrm{ev,} \mathrm{p.} 1$. 
near the plant, in a security zone in which such a grouping would never before have been tolerated, even in Western countries. ${ }^{2 \%}$ The protest appears to have been somewhat haphazard, and it is not clear if any organized group was responsible.

The accident brought the question of nuclear power safety to the fore. The problems are numerous. At a press conference after the accident, it was made known that the city does not have a center for coordinating actions in emergency situations. As a result, various services and organizations, including the city Soviet, did not receive as timely a notification of the accident as they should have.130 As well, up to the present, there is no law concerning atomic energy use. Although a draft is being worked on, a law governing atomic power will not likely be passed until later this year or 1994.131

Under the Soviet nuclear program, radioactive wastes from power plants were stored near the site of the plant itself. And, in fact, David Marples says the practice

12.9 Le if Svenson, "Rärnkraft i Ryssland," [Nuclear Power in Russia, ] summer 1992, pp. 1-3, and personal correspondence, 11 November 1992, summarized in English for the author.

130 Serges Kraiukhn, "Leningrad Atomic Power Station: Inspection by and help from International Atomic Energy Agency Are Needed," Izvestiia, 26 March 1992: 2; Current Digest of the Soviet Press, 12 $(1992)$, p. 32 .

131 Lina zernova, "Atomnaia energiia est. Zakona o ee ispol'zovanis net," [We Have Atomic Energy, but No Law on Its Use,] Ni'lisko viemia, 1 May 1992, p. 2 . 
continues.' 32 The danger to major population areas near the plants is immense. Matthew Sagers claims that, in 1989, a leak of radioactive wastes from the Leningrad power station's storage facility did occur, ${ }^{133}$ although the damage was apparently minimal. A journalist who visited one of the storage sites last year claims that the sites were never open even to civilian inspection teams, perhaps because of the military research being carried out in the area. Some of the nuclear storage sites, he claims, are slated for burial, a practice that is environmentally questionable. 114

The thermoelectric power and heating plants of the city, which ran on coal and fuel oil, emitted huge amounts of sulfur dioxide.135 As Goldman reported in 1969, there were 40 percent fewer clear daylight hours in Leningrad than in the town of Pavlovsk, only 35 kilometers away, chiefly due to the discharge of dirty air from chimneys. ${ }^{3 *}$, In a similar vein, Keith Bush attributes the phenomenon to "...industrial haze aggravated by the low-grade fuel used."1:7 Fortunately, there was much conversion to cleaner-burning natural gas. Prior to

132David Marples, "The Post-Soviet Nuclear Power Progiam," presentation at conference "Environmental Security After Communusm, and subsequent interview, Ottawa, Ontario, 26 February 1993. p. 313 .

$133^{3}$ atthew 5. Sagers, "News Notes," Soviet Geography, Apr $1114 \% 1$,

134 Svenson, "Kärnkraft...," pp. 6-7, and persond correspendence.

135 see komarov, p. 41.

${ }^{136}$ Goldman, Spoils..., pp. 137 .

137 Bush, "The Soviet Response...," p. 14. 
1970, the level of air pollution in Leningrad alone was said to have been reduced by over 808 by switching to natuial gas.:38

Although pollutants from the transport sector are difficult to measure, it is known that the sector is increasing dramatically, and its share in polluting is as wel1.139 Motor transport in Leningrad in 1987 accounted for 598 of total emissions and the greatest proportion of many pollutants, including 798 of hydrocarbons and 888 of carbon monoxide. 140

Sewage sludge from water treatment plants is kept at a sludge storage site. Like the alfresco storage of cattle waste, depositing the sludge in open air basins causes contamination of soil and water through leakage, whi:e harmful bacteria and viruses are spread through the air or carried by rodents or scavengers, risking disease. ${ }^{141}$

708 of municipal waste is dumped into landfill sites. According to a study by the Finnish Ministry of Environment, accurate information about landfills is not available, but, "...it can be assumed that great problems caused by poor landfill management exist. Inadequate compaction, missing soil cover and poor leachate [liquids percolating through the soill and overflow control cause pollution of surface and

$138_{\text {Bush, }}$ "The Soviet Response...," p. 13.

139 peterson, "...The Air," p. 6.

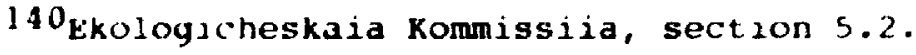

14 Manstry of the Environment of Finland, p. 81. 
ground water." Fires are common at uncontrolled sites, and the burning of wastes adds new components to atmospheric pollution. Finally, there is the hazardous practice of disposing of industrial, and even hazardous, wastes together with municipal wastes.142

Since 1970, toxic industrial waste has been sent to the Krasnyi Bor site, 30 kilometers from St. Petersburg. ${ }^{14.3}$ The landfill opened for a 5-year trial period, but has been in operation ever since, also on a trial basis. ${ }^{144}$ Since neither the technology of current waste disposal equipment nor its technjcal condition enable the center to meet environmental protection needs, the site is on the verge of being abandoned. Still, its final shut-down is being forestalled due to a lack of alternatives. A reconstruction plan based on acquiring modern Western technology is estimated to cost 32 milition 1990 rubles. 145 The site now receives almost 91 thousand tons of hazardous wastes a year. Currently, a system of collection and disposal of hazardous wastes from the household, trade, and services sectors does not exist.14t, Krasnyi Bor receives material from some 800 enterprises in

14.Ministry of the Environment of Finland, 4.79. 143 KONSOFIN, p. 37 . 144 Ministry of the Environment of Finland, $p .79$. 145 KONSOFIN, p. 37 . 146 Mnistry of the Envircnment of finland, $p . " 2 \%$ 
the city, as well as from other regions and, under the Soviets, received waste from other republics.147

Local problems are exacerbated by the quantity and quality of materials brought in from outside the region. Toxic and radioactive waste from other areas of the country are imported into the area. The Krasnyi Bor site, for instance, receives waste from 14 other regions. Other hazardous substances like pesticides are often imported into the area in amounts in excess of needs, not to mention of a different variety than needed. Unused toxicants must then be disposed of 148

\section{THE SOCIO-POLITICAL SETTIHG}

Local socio-political factors have an important place in the ecology of the region. Societal attitudes, education, environmental movements, and the political decision-making apparatus all have roles to play.

\section{Ecological Administration}

In the main, the local ecological administration of $\mathrm{St}$. Petersburg is divided among the following three bodies: City Council, the Mayor's office, and Lenkomprircia. I will detail each body's role.

City Council, or Petrosoviet (formerly Lensoviet), consists of 380 deputies, elected for five-year terms, 149 the

\footnotetext{
147ministry of the Environment of Finlaud, p. 79.

148 Leningradski1 nauchnyi tsentr, p. 8 .

140 Exactia, section 2.2 .
} 
last election having been in 1990.150 As was common in local elections throughout the country, where an estimated 998 of candidates included environmental control requirements in their platforms, 151 a great number of deputies were elecied espousing environmental themes. Though actual distinct political parties did not partake in the last elections, the Green Party alone has 18 members in the Petrosoviet.15:

The City Council is divided into more than 20 standing commissions, 153 through which it manages the many areas related directly and indirectly to environmental issues undes its jurisdiction. The Council's fundamental task deals with urban development. Thus, questions involving infrastructure, industry, and many other areas touch on environmental issues, while thi ee involving sanitation, resource management, and the like, are more directly related to the environment. $i^{t, 4}$ A similar structure exists for the region, called Lenoblsoviet, with an executive committee working under the supervision of the Regional Council. Under this committee are the Environmental Protection Department and Forest

\section{Pomagaev.}

1510leg Ianitsk11, "Ekologucheskie dvizhenl1a na vestokes I ladpalde: skhodstvo i razlichiia," [Ecological Movements in the East and the wait: Similarity and Differences, ] Mirovaia ekonomika I menhunarodny" otnosheniia, 4 (1991), p. 36.

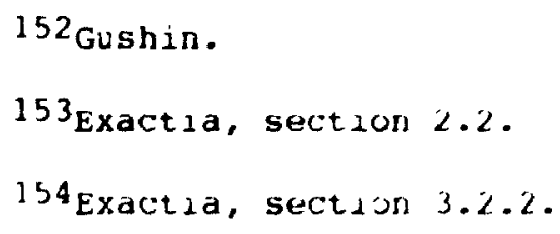


Administration, $2 \leq \pm$ controlling the main ecological activities of the region.

Legislative functions of environmental control belong to the Ecological Commission of the Petrosoviet and Lenoblsoviet. The commission in City Council consists of 20 members, chosen on the basis of their personal interest in ecology, and convenes once a month.156 According to City Council Member Georgii Stadnitskii, none of the members of the commission is a professional ecologist. 157 The structure consists of a chair and three vice-chairs, responsible for economic matters, nature protection, water management, environmental education, and international relations. Although its decisions are not binding on other administrative units, the other units are requested to respond to its decrees by reporting on steps taken within a period of time allotted by the commission itself.158

The next major player in the local political scene is the Mayor's office. The office is the legal successor to the now defunct City Executive Committee, and is divided into some 20 comnittees, five of which are directly related to environmental issues. They are the Committees for: Urban Development and Management of Public Roads; Housing and

1' SMinistry of the Environment of Finland, p. 91.

156 Exactia, section 3.2 .2 .

$15 \%$ Georg1 stadnitsk1i, personal interview, 4 July 1992 , St. Petersburg, Russta.

158 txactia, section 3.2 .2 . 
Energy; Construction, Reconstruction and Use of Land; Public Safety and Prevention of Imergency Situations; and Land Resources and Land Reform. 250 Each committee has extensive power within its jurisdiction, with administrative, operational, and inspection units within each committee concretely carry out measures. 160 The Mayor's office is limited by Petrosoviet, which prepares the annual budget in: and thus, at least in theory, defines financially what the Mayor's office can do. Nonetheless, despite City Council's control of the purse strings, the Mayor's of $\mathrm{ice}$, accordiny to one City Council member, holds the real power and of ten pursues an independent path free of constraints.i...

The third major player, the Leningrad Committee for Environmental Protection, or Lenkompriroda, has responsibility for environmental protection of the city and region. Established in October 1988, Lenkompriroda operatess under the supervision of the Russian Ministry of Ecology and Nature-Use, as well as the City and Regional Councils. It consists of 250 members, headed by a Chair and three ViceChairs, each heading one of three functiona' units: environmental inspection, scientific analysis, and

159Exactia, section 3.2.3. Although Petresoviet memtrer Stadnitskii claims there is a Comittee for Nature Usf withan thr: Mayor's office, I have not been able to find other references i", See Stadnitskil.

$160_{\text {Exactia, section } 3.2 .3}$

161 Ministry of the Environment of Findand, pp. yo-"l.

162 Stadnitskil. 

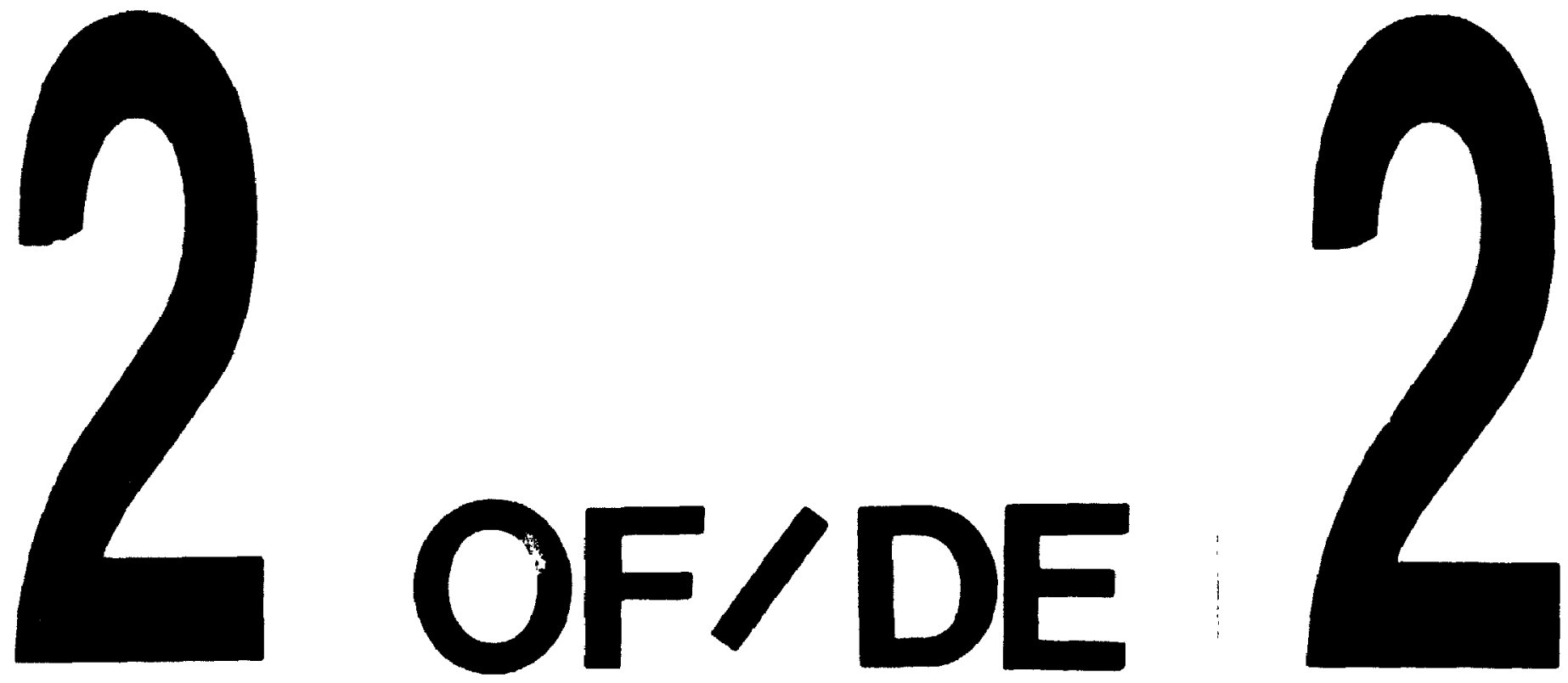

PM-1 31/2" $\times$ 4" PHOTOGRAPHIC MICAOCOPY TARGET NBS 1010 a ANSI/ISO \#2 EOUIVALENT

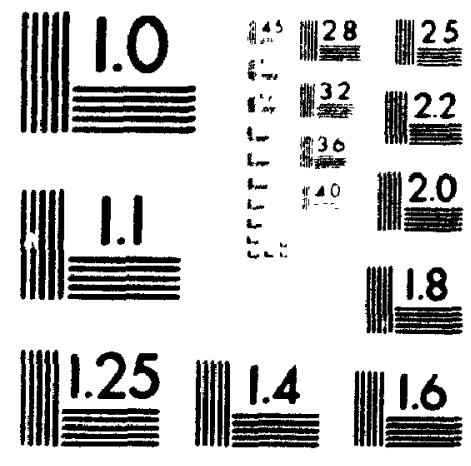


technological operations. 163 Lenkompriroda's main functions are to control environmental activities in the region; to oversee and prevent water pollution from ships and boats; to control analysis of effluent and emissions; to control the use of natural resources; to provide ecological expertise and approve project documentation for construction; and to implement scientific research. 164 Lenkompriroda is, in essence, the executive branch of environmental control.165 Other bodies have a role in the region's ecological matters. A Department of Environmental Protection within the City and Regional Executive Committees had a role in environmental protection, taking on executive functions, le.t. although its status since the dissolution of the Executive Committees and the extent of its powers and role is not clear. Inspection duties of the Gulf of Finland fall under the Sea Inspection Committee of Leningrad, while the Neva River and Lake Ladoga are covered by a similar body, the Water Resource Association Cf the River Neva and Lake Ladoga. Both organizations operate under national bodies and the city and Regional Councils.167 In addition, there is the local branch of the already mentioned State Sanitary and Epidemiological Service.

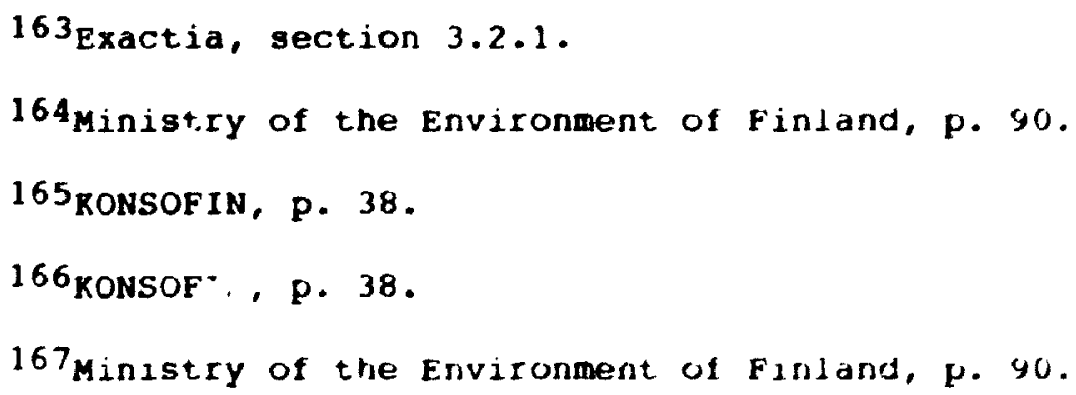


Barbara Jancar points out that Leningrad, as well as some other large municipalities, instituted a comnittee for environmental protection in order to counteract the lack of local influence in the face of central economic bodies. 168 The committee in Leningrad, as it was comprised in 1979, consisted entirely of officials engaged in environmental protection and pollution control; conspicuously absent were representatives from industry. The committee had no administrative power. Its functions were purely advisory and fell into 4 major areas: to coordinate activities of organizations involved in environmental work in the city; to prepare recomnendations to municipal executive committees concerning environmental protection and natural resource use; to evaluate applications for construction and development permits; and to exercise control over enterprises and organizations in compliance with environmental regulations.

The committee was divided into subcommittees and, according to some members of the various subcommittees, no construction project could go forward without review from one of the subcomittees. The committee could request information from questionable enterprises, return project. requests for modifications, and submit the names of enterprises and directors to Gorispolkom (the City Executive Comittee) for action. According to Jancar,

168 Jancar's information on the comittee was based nearly solely on an interview with one member, and one must question her positive assessment of the committee in view of the system already discussed and the ecological quagmire the city finds itself in. 
[ $t$ ] he role of the environmental committee and the Gorispolkom in achieving environmental results should not be lightly dismissed.... In Leningrad, the environmental committee was able to generate the momentum to have some sixty factories moved out of the city.

She claims that in Leningrad, because of a far-sighted governmental administration and some political influence, the active environmental protection committee provided some coordination and supervision. Nevertheless, she concedes, "The need for central furding and the branch ministerial chain of command set definite limits to the control exercised by these committees over resource use within city boundaries." 169

Environmental funds come from various sources. Under 1988 legislation approved by the City Executive Committee, fines for exceeding discharge norms were raised, corresponding to the level of contamination, and the $f$ ines collected are transferred to a special account for improving the local ecological situation.170 This Environmental Protection Fund is disbursed by the City and Regional Councils, on recommendation from Lenkompriroda. Still, the importance of the Environmental Protection Fund in total ecological funding is rather insignificant.171 Funds are also disbursed on the national level by the new Ministry of Ecology and Nature-Use. In 1991, St. Petersburg received 39

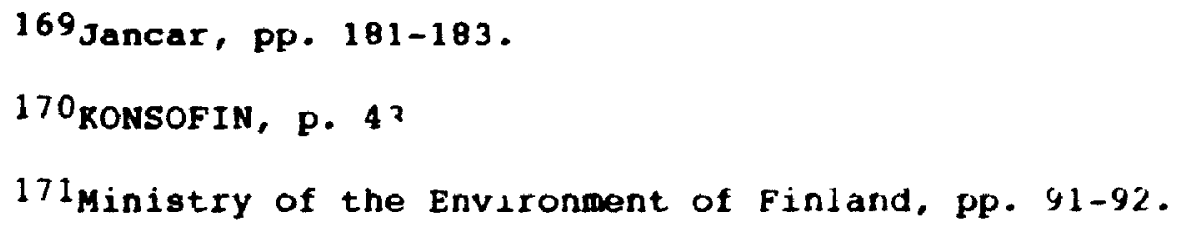


billion rubles from the central government, all of which went to flood protection. 172 Consequently, other local

environmental needs must receive funding from other sources, including the city budget and commercial sources. However, fiscal conditions are such that money, especially hard currency, is in short supply, with all available hard currency paying for food programs and medical supplies. In fact, no hard currency went into environmental programs in 1991 and none was available for the environment in 1992.173

Information and Media

While the average citizen simply had no access whatsoever to data, numerous hurdles awaited even those in the field whose work demanded information. Researcher Valerii Karpov describes the difficulty he encountered in attempting to retrieve records. Information on air and water quality was printed in secret books. He first had to go to the director of his institute with a written explanation of why he needed the book. If the director agreed, he was then given a stamped letter asking the library to show the necessary book. At the library, from a carefully guarded section, Karpov received the information he requested. But books of this kind were few in number and intended for Communist Party use only. 174

172 Exactia, section 5 .

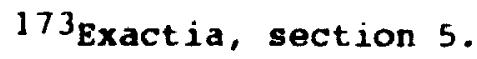

174 Karpov. 
Open publication of environmental statistics is a very recent phenomenon. In St. Petersburg, only two or three years ago did local newspapers begin printing such figures. For inst ince, the newspapers Smena and Leningradskaia pravda (now Sankt Peterburgskii vedomosti) each week printed levels of cadmium and $z$ inc in the Neva. 175

Problems with information arise partly because of past practices and partly because of inadequate informationgathering technology. Karpov says he knows of only two or three places in St. Petersburg employing what he deems to be good technology in their information-gathering, all of them beirg in the defense industries. And the ignorance pervades both the grass-roots and official levels.176 One Russian expert claims that, even though the records and archives are open, one cannot necessarily find adequate data there. Decisions in the past were often made by just one or two people and the process was such that the decision cannot even be traced to the responsible party. 177

The Environmental Movenent

As already mentioned, few, or more accurately, no opportunities existed for independent environmental groups in the pre-Gorbachev period. To be sure, environmental groups

175 Rarpov.

$176_{\text {Karpov. }}$

$177_{\text {Raphael Vartanov, "The Russian North and Environmental }}$ Security," presentation at conference "Environmental Security after Communism," Ottawa, Ontario, 26 February 1993. 
existed even in Imperial Russia, including St. Petersburg, 178 but beginning with the late N.E.P. period, the movement was reined in by the government. Leningraders working for the environment before 1986 usually did so through the All-Union Nature Conservation Society or through various official recreational societies.179 An ad hoc local preservation group, the Leningrad Society for the Protection of Cultural and Historic Monuments, also existed in Leningrad, 180 and indirectly took up the environmental cause.

Environmental groups did not openly question the party or economic system, nor did they engage in independent politicking or demonstrating. For st. Petersburg, the first autonomous public demonstration came in 1987 with the public opposition to the tearing down and renovation of a hotel complex including the hotels Angleterre and Astoria. The action eventually spawned other independent social movements. ${ }^{181}$ For this reason, the incident, although not a direct environmental issue, is important to look at. In addition, it reveals fundamental problems in the political decision-making process.

The Angleterre Hotel, where the poet Yesenin hanged himself, had stood empty for two years. As rumors spread in March 1987 that the hotel would be razed, a group of mostly

178 see Weiner, Models..., p. 16.

179 Exactia, section 6.2 .

180 Pryde, Environmental Management..., p. 247.

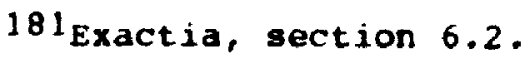


young people, organized by the Council for the Ecology of Culture but consisting of members of Komsomol and ouher groups concerned with environmental protection and restoration of monuments, appeared around the site, picketing, collecting signatures on a petition, and preventing suspicious vehicles from entering the area. Representatives even addressed the City Soviet Executive Comnittee, where they received assurances from the First Deputy Director of the Chief Administration for Culture that the building would not be demolished. Nonetheless, rumors continued and the protest mounted, and, a few days later, the Vice-Chair of the Execitive Committee met with protestcrs. He assured them there was no problem and that their opinion would be conveyed to the Executive Committee. The protesters returned to the Angleterre, but an hour later, a police Iine moved them back, wrecking equipment enterıd, and the building was demolished.

Several days later on March 21, hundreds of protesters gathered again in the square outside the building while demolition continued. The demonstration unfolded peacefully. with police merely requesting protesters to ailow traffic to proceed around them. Demands were made for greater input into decision-making and an investigation to determine what had happened. 182

182 Mikhail Chulaki, "Once More About the Value of Openness," Literaturnaia gazeta, 25 March 1987: 10; Current Digest of the Soviet. Press, 14 (1987), p. 7 . 
Subsequent meetings with officials were held to determine future policy, why things happened as they did, who was responsible, and so forth.183 Significantly, even after the building was torn down, rendering the original goal of preserving it inconsequential, protesters continued the vigil and garuering of signatures for a petition demanding an investigation, one insisting "We do not want this kind of thing to happen again." 184

The event betrays many of the usual patterns in these matters. There were lies and obfuscation, as officials made : assurances, up to just hours before the fact, that the building would not be torn down. In the bureaucratic and legal anarchy of the system, it is not even clear that all leaders knew of the impending fate of the building, thus explaining their reassurances to protesters. One of the protest leaders was detained and later released. Other participants were investigated and some refused admittance to universities, 185 while legal cases were readied against some of them. 186 Some officials retreated to reticence, with the Chair of the City Soviet Executive Committee refusing

183 See Nikolai Bodnaruk, "Trudnoe proshchanie s proshlym," [A Difficult Farewell to the Past, ] Izvestiia, 25 April 1987, p. 3, and Chulaki, p. 7.

184 Bodnaruk, p. 19.

185 A. Ezhelev, "V odnoi lodke: o tom, kak utverzhdaetsia novoe myshlenie na slovakh i na dele," [In One Boat: How the New way of Thinking is Being Established in Words and Deeds, I Izvestila, 1 August 1987 , p. 3 .

186 A. Ezhelev, "Komu urok?" [A Lesson for Whom?] Izvestiia, 27
March 1987, p. 6 . 
personal interviews, limiting himself to saying that "Everything was done correctly." Documents from the Russian Republic Ministry of Culture, recommending further study with a view to preserving the building, were ignored, while those cited by one official as justification for the demolition were written a week after the razing itself. The Executive Committee Chair claimed not to have received until 30 March a telex from the U.S.S.R. Ministry of Culture ordering a cessation of work and dated 27 March. 187

A spate of articles and letters to the editor in local and central newspapers, as well as radio and television reports, appeared during and following the razing. Opinions seemed to be vehemently pro or con vis-à-vis the protest. Izvestiia, in particular, heralded the protesters and their cause, and received the rancor of some officials.

The incident was a watershed and brought about important changes for Leningrad. The city received a strong, up-close dose of protest, particularly since the goings-on proceeded in the middle of the city in St. Isaac's Square. The old system was examined and re-examined daily under the press's microscope. And the way was cleared for future cooperation and, when necessary, confrontation, between officials and private groups and citizens.

By the last nine and half months of 1987 , over 30 applications for conducting "mass-participation events in

187. Ezhelev, "Urok ne vprok," [The Lesson is of No Use, ] Izvestila, 9 April 1987, p. 6. 
public places" were filed in Leningrad. Of these, 11 were approved, but even the others demonstrated anyway.188 Because no All-Union legislation existed on the matter of demonstrating, Leningrad and other regional soviets adopted temporary regulations. In Leningrad, that legislation stipulated that an application must be filed 10 days in advance and written approval must be received from the Executive Committee. 189 On the 17th of May, 1987, just a few days after its founding, the ecological group Del'ta conducted a demonstration in the city. On the 19th of May. according to one of the group's founding members, City Council made a decision, which was to take effect immediately, putting restrictions on demonstrations. 190

St. Petersburg has seen the rise of numerous public, independent environmental groups since the mid-1980's. One estimate puts the number in $5 t$. Petersburg at around 40 as of January 1991.191 The best-known major early campaigns included a march by 12,000 people protesting emissions from a biochemical plant in the town of Kirishi in 1987, the fight against the pulp and paper mill in Priozersk, and opposition

188 Ronstantin Mikhailov, "Who Can Demonstrate? It's a Local Matter," Sobesednik. 3 (1988): 7; Current Digest of the Soviet Press, $10(1988)$, p. 15 .

189 Mikhailov, p. 15.

190 Petr Kozhevnikov, personal interview, 1 July 1992, St. Pete- burg, Russia.

191 Exactia, section 6.2 . 
to the dam construction across Nevskii Bay in the Gulf of Finland. 192

\section{Population Pressures}

It has been estimated that 30 to 408 of the environmental. damage being inflicted on the Leningrad region is attributable to the increasing population rate.19.3 One concrete example is cited by Braden: in 1967,450 people visited the forests on the Valaam Islands in Lake Ladoga. By 1979, that number had risen to 130 thousand.194 In the $1970^{\prime} \mathrm{s}$, Leningrad received some 50 thousand immigrants per year. In the 1980 's, shat flow was reduced to 30 thousand per year. However, according to St. Petersburg University's S. B. Lavrov, even this restricted growth aggravated the environmental problem. At the First Congress of People's Deputies in 1989, a brigade leader from Leningrad proposed curtailing growth of large cities, as well as stopping expansion of industry within these cities.195

Regarding population pressures, an interesting twist to the problem of low technology has arisen in st. Petersburg. Enterprises continue to be built with technologies over 20 years old, and the low scientific and technological standards

192 Pryde, Environmental Management.... pp. 250-251.

193 Geral d Shalabin, "Soiti s dorogi, vedushchei $v$ nikuda," [Getting off the Path Leading to Nowhere.] Nevskoe vremia, 8 May 1942. p. 2.

194 Braden, p. 603.

195s. B. Lavrov, "Regional and Environmental Problems of the U.S.S.R.: A Synopsis of Views From the Soviet Parliament," Sovirat Geography, September 1990, p. 496. 
demand a constant injection of non-qualified labor into the area. This adds to the concentration of population in industrial centers, increasing human-made pressures on the environment and wasting rural territories. This takes place while one of the country's highest trained labor forces, in the city of St. Petersburg, goes underutilized.196

Due to lack of foresight and ljttle regard for the future inhabitants of the target areas, urban planning was not always adequate, usually concentrating on short-term economic gains. Goldman reports that, on a trip to Leningrad in 1968, he visited a sanitary treatment plant in the vyborg district. It was surrounded by the 50,000 inhabitants it served, with the only water source a 10-foot wide stream. The plant had just been built in 1957, but was expected to be scrapped in 1973 in favor of a more efficient plant. Meanwhile, the population was already overtaxing the new facilities. 197

From current figures, it seems also that poor planning has left a population with little green space for recreation. At present, the green area of St. Petersburg totals 15,318 hectares, or 278 of the city. ${ }^{298}$ If one assumes a population

196 Leningradskii nauchnyi tsentr, p. 7.

${ }^{197}$ Goldman, spoils.... pp. 100-101.

198 Gosudarstvennyi Komitet SSSR Po Statistike, \{U.S.S.R. State Committee for statistics, j Okhrina okruzhaiushchei sredy i ratsional noe ispol'zovanie prirodnykh resursov v SSSR: statisticheskii sbornik, [Protection of the Environment and Rational Use of Environmental Resources in the U.S.S.R.: Statistical Handbook, J Moscow: 1989, p. 19. 
of 4.5 million, 199 this amounts to a mers 3.4 hectares per one thousand people, which would make it one of the lowest ratios of major cities in the country. Indeed, the oblast is devoid of national parks 200 and has only one zapovednik, or protected nature study area, located on the eastern shore of Laduga near the mouth of the Svir' and covering only 41.4 thousand hectares . 201

\section{Environmental Law}

5t. Petersburg can boast of few environmental lawyers, and those that exist have little experience. In addition, the term 'legality' itself remains ambiguous, and laws tend to be weak.202 Recently, for instance, Lenvodakanal, a municipal organization in charge of st. Petersburg's water supply, rejected a request by Lenkompriroda to show the agreement signed between Lenvodakanal and a French $\mathrm{f}$ irm concerning a new water system in St. Petersburg. Lenvodakanal simply responded that the agreement was a secret and refused to show it. Its reaction was completely unlawful, but no action was taken against it.203

Other legal and quasi-legal questions abound. The agreement has left many wondering about the soundness of the

199 Information Please Almanac, (Boston: Houghton Mifflin Company, $1993)$, p. 252 .

200 Pryde, Environmental Management..., pp. 136-170.

201 cosudarstvennyi Romitet, p. 121 .

202 Aleksander Aleksandrov, personal interview, 12 Junt 1992, st. Petersburg, Russia.

203 Aleksander Aleksandrov. 
deal. It seems that in arranging the agreement, laws were broken when city council was not consulted, anti-monopoly laws were unheeded, and the foreign company was illegally registered. In addition to the outright violations, moral questions have arisen concerning the profits to be made by the French firm, local sovereignty over resources, and lack of competition in awarding the contracts. 204

These, then, are the local factors that have had a part in defining the ecological problems of st. Petersburg. Together with the national roots, they have given the area its unique environmental characteristics. With this in mind, we can now proceed to an analysis of the situation as it currently stands, with an eye on how future developments could unfold.

204 Tsvetkov, Sergei, "Vodokanal'-na chistuiu vodu!" [Vodokanal-to clean waterl] Nevskoe vremia, 19 February 1992, p. 2. 


\section{ECOLOGICAL ANALYSIS AND FUTURE PROSPECTS}

With the historical background and thorough assessment of the present situation in St. Petersburg, we can now analyze St. Petersburg's environmental prospects. I do not wish to conjecture about what will take place in the city's future, but rather to assess predominant problems and what measures can and need to be taken to mitigate them.

The ramifications of the current environmental situation are startling. St. Petersburg has one of the highest disease-incidence rates in the country. The Leningrad Science Center of the Academy of Sciences claims that 75-958 of oncological diseases are governed by the environment, and the death rate from oncological diseases in St. Petersburg is 228.1 This means that between 16.5 and 218 of deaths in the area are attributable to the environment. Neariy one third of the population of the city is affected by diseases of the upper respiratory tract. ${ }^{2}$ Fifty per cent of the city's schools are contaminated with lead vapors, ${ }^{3}$ and Leningrad's Chief Pediatrician considers only 0.78 of the city's children to be healthy.4 Assuming even a small fraction of the number

\footnotetext{
${ }^{1}$ Leningradskii nauchnyi tsentr, p. 13.

2 "Russia's Greens...." p. 24.

31. Luchin and v. Vinogradov, "Eshche paz o parakh tidt," fOnres" Again about Mercury Vapors, ] Vechernii Peterburg, 6 Febrliary $199 \%, p . \%$

${ }^{4}$ Leningradskii nauchnyi tsentr, p. 14.
} 
of unhealthy children is due to environmental factors, the toll is quite large.

In Lake Ladoga, salmon catches have decreased from a maximum of 200 tons per year in the 1950 s to less than 5 tons presently.5 In some aquatic areas, cash species, like sturgeon and salmon, are threatened with extinction. Close to extinction as well are a number of bird species, and migrating and nesting bird populations continually decrease in number at the same time that scavengers, like crows and gulls, are multiplying so rapidly as to disrupt ecosystems. Similar conditions exist with small mammals. 6 Hundreds of lakes in the Ladoga basin are biologically dead.?

\section{ECONOMIC PROSPECTS}

Without a doubt, the biggest factor in how environmental problems will be tackled is the economy. The state of the economy will determine the future state of the environment. Conversely, a poor environment is not without its effects on the economy; in all, economic costs from pollution in the Leningrad region amount to not less than 1.25 billion rubles per year (in 1989 prices). ${ }^{8}$

The extensive model of economic growth is consuming huge amounts of resources and spewing their byproducts into the

\footnotetext{
5rorhonen, p. C9.

6Leningradskii nauchnyi tsentr, pp. 12-13.

7N. 01 'gina, "Govoriat, shpiony vodu otravili," [They say That spies Poisoned the water,] Vechernit Peterburg, 23 November 1991, p. 1.

${ }^{8}$ shalabin, p. 2 .
} 
air, water, and soil. Yet, economic output continues to be based upon this model. Recent figures indicate that resource content per unit of gross domestic product in the U.S.S.R. was about twice as high as in the United States, and somewhere around four times more than in some Western European countries.9 Similarly, according to the C.I.A.'s 1989 figures, the U.S.S.R. produced $\$ 253$ of G.N.P. for every barrel of crude oil equivalent consumed. In the United States, the figure is $\$ 341$, and in Japan, $\$ 639.10$ The fact is that the country has neither a comprehensive program for economizing resource use nor mechanisms to control the process. What is more, planning and control bodies continue to use indices for raw material and fuel consumption that have proven to be faulty in the past.11 As easily attainable resources become exhausted, as the toll from pollution due to high input use rises, and as more accurate pricing of inputs leads to economic bankruptcy of enterprises failing to curtail resource use, it is imaginable that industry will necessarily move toward an intensive mode of production. Still, recent figures shed a pessimistic light on resource use.

Poor economic conditions hamper the pro-environmental forces. The help of science in the ecology field is indispensable, yet many economic roadblocks to proper

${ }^{9} \mathrm{Gel}$ ' vanovskii and Trofimova, p. 130 .

10 Peterson, "...An Gverview," p. 16.

$11_{\mathrm{Gel}}$ vanovskii and Trofimova, p. 131. 
scientific work exist. That scientists in the former U.S.S.R. are not paid as well as their Western counterparts is no secret. But as economic times worsen, a possible brain-drain could result throughout the country. The consequences for the environment would be devastating if the country's scientific elite decided to emigrate to better conditions. Already there are cases of this very phenomenon taking place in the environmental sphere. 12

The generally poor economy further impedes scientific activity. Modern equipment and technology, available only for hard currency from the West, are lacking. A report in Voprosy ekonomiki flatly states that "...the technical parameters and quality of current environmental control equipment cannot fully guarantee preservation of human health." 13 Valerii Karpov bolsters that view, maintaining trat the two principle environmental monitoring agencies, the Ministry of Hydrometeorology and the Ministry of Public Health, together can measure only about 26 parameters of water quality because of pror equipment, and many of those parameters are not of great importance. Although some special scientific organizations have good equipment, even they can attain a maximum of only 52 parameters, and this being only periodic limited samples. This he contrasts with

\footnotetext{
12 See Sergei Tsvetkov, "Peterburgu-chistaia voda?" [Clean Water to Petersburg?] Nevskoe vremia, 4 February 1992, p. 2.

13T. Ivanovna and N. Glovatskaia, "Kriterii i printsipy formirovaniia ekologicheskoi politiki," [Criteria and principles for Forming an Ecological Policy, ] Voprosy ekonomiki, 11 (1990), pp. 82-83.
} 
the 1 thousand parameters measured continuously in the Great Lakes in North America, and the portable Gret..peace bus that visited Leningrad two years ago, measuring 5 thousand water parameters. 14

The green movement is likewise stifled by the poor econony. According to Iiana Dobrykh, green groups can rail against particular harmful factories, but the plants can not be shut down. No action will be taken because of the loss of important output. She continues:

The functions [of green parties] are important in a post-crisis period, but not now. Many factories are becoming bankrupt, so there are no measures you can take against them. During normal times, people can be punished, measures can be taken, but not in this period of crisis. 15

Another result of the poor economy is waning public interest in the environment. A populace preoccupied with meeting its food and material needs can not be bothered by ecological problems. Already the economic crisis is leading to ecological apathy. Georgii Stadnitskii refers to a survey of the population, done some three years ago, in which environmental quality occupied second place in importance among several topics; just two years later, it had already dropped to sixth place. 16

As economic times worsen and workers strive to keep their jobs, a conspiracy of silence may begin to pervade

14 Karpov.

15Iiana Dobrykh, personal interview, 26 March 1992, st. Petersburg, Russia.

16 Stadnitskii. 
places of employment. As previously mentioned, this silence was in evidence at the nuclear accident at Sosnovyi Bor in March 1992. Stadnitskii spoke of the phenomenon at various government departments and industry.17 The silence could hamper investigations and openness as workers, motivated by fear of job losses from the closing of offending factories or outright individual retaliation by managers, refuse to reveal the real situation and spokespeople and bosses merely parrot management's line. Tough whistle-blower laws would be conducive to preventing this phenomenon.

\section{Industry}

As the economy shifts from the central command type, responsibility for treating pollutants more and more rests with the individual enterprises. Privatization, decentralization, and khozraschet, or self-financing, bring with them the hope of solving the environmental disruption caused by the inherent deficiencies of the former command economy: departmentalism, environmental self-regulation, and a host of other problems explored earlier can be done away with. On the other hand, enterprises that are cut loose by the market will, as their counterparts throughout the world have already demonstrated, seek to externalize environmental costs in order to turn a profit. In this manner, industry's move to self-financing might actually make things worse by making managers even more interested in profits and less interested in investing in environmental controls, since the

17 stadnitskii. 
profits will stay with the industry itself.18 Although this is not different from the situation as experienced under capitalism, until a proper and enforceable legal system is in place to make the cost of polluting more expensive than controlling it, the move to khozraschet will be environmentally upsetting.

Besides the problems encountered by capitalist countries with regard to pollution by private enterprise, privatization has other drawbacks. One problem in the post-communist world is that investment, at least according to the Latvian experience, tends naturally toward those industries that yield the highest, quickest return. As a result, industries concerned with environmental clean-up, which require a longer period of return, are ignored.19

More consumer goods will be produced in the future, with less emphasis on heavy industry. This trend is promising, for heavy industry is more damaging to the environment and accounts for most of the pollution in the country. 20 Yet, as experienced in the West, the consumer economy is a large contributor to environmental degradation, especially in the post-production phase through the waste generated. St. Petersburg's household waste, which stood at $4.3 \mathrm{mill}$ ion cubic meters in 1985, is projected to rise to 9.4 million

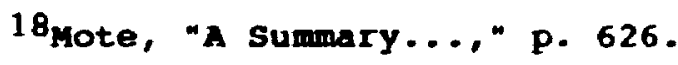

19 "An Interview with the Chairmen of Latvia's Two Environmental Protection Agencies," Eco Logic, (Quarterly publication of the Environmental Protection Club of Latvia Elpa, J January 1992.

${ }^{20}$ Lemeshev, p. 74 . 
cubic meters by 2005,21 an increase of about 1198 . An underdeveloped and unprepared infrastructure, as present?y exists, would be all the less able to cope with the problems of an economy based on mass-consumption. As St. Petersburg aims to grow economically, it must be prepared to take on these new problems.

Nonetheless, if the problems and mistakes made in the West are taken into account, the shift to capitalism is promising. However, expectations that the emerging economic system is a panacea are unfounded. As Geral'd Shalabin, economist at St. Petersburg University, notes, the city's current economic status is not one in which market mechanisms are taking care of environmental concerns. In fact, the market being established smacks of the wild, primitive capitalism reminiscent of the 19 th century. Market methods, he asserts, are only effective under stable economic conditions.22

Industrial output has trebled over the last 30 years, and recent branch development schedules indicate that planners intended to increase st. Petersburg's industrial output by 1.5 to 4.5 times by the year 2005. At such a rate, according to one study, "...without radical changes in current technologies, catastrophic degradation of the ecosystem and of the quality of the environment are

\footnotetext{
$21_{\text {MONSOFIN, p. } 34}$

22 shalabin, p. 2 .
} 
imninent."23 More generally, the question arises as to whether the region's environment can support such a huge economic expansion. Radical mitigating steps must be taken to ensure ecological survival.

with increased economic growth will come larger numbers of people and the accompanying pressures on the environment. A 1988 study by the Institute of Geography of the U.S.S.R. Academy of Sciences broke down the European part of the U.S.S.R. into environmental zones. The conclusion: the Leningrad region showed the highest level of human-made pressure on the environment. 24

Because of its highly skilled work force, the presence of many academic institutions, its rich history and scenery, the numerous cultural facilities, and the easy accessibility for foreign tourists, there is the possibility to re-orient the city of St. Petersburg to a hub for science, engineering, culture, and tourism, and away from being a major industrial center. ${ }^{25}$ The prospects for the tourist industry are particularly good, given the city's location as a window on Europe and the use that could be made of the area surrounding the Gulf of Finland. The group Coalition clean Baltic has proposed a tourism scheme for the Polish area on the Baltic, and there is no reason to believe the proposals could not be implemented in the st. Petersburg region. The report

\footnotetext{
23 Leningradskii nauchnyi tsentr, pp. 5-6.

${ }^{24}$ Leningradskii nauchnyi tsentr, p. 10.

${ }^{25}$ Leningradskii nauchnyi tgentr, p. 17.
} 
believes that privatization will reshape the tourist and health industry of the coastal areas. Previously state-run sanitaria, frequent polluters of the waters with their discharges of raw sewage, will disappear, and the coast will attract capital in search of tourist dollars. 26

The pulp and paper industry, a large player in the local area, will continue to have problems. Again, Mildred Turnbull:

The ecological outlook for the pulp and paper industry is especially grim, because its ability to make ecological improvements is constrained by unresponsiveness on the part of the machinebuilding industry.... These circumstances, in their turn, may trap the industry within a catch-22 situation, as it is the declared intention of nature protection authorities to levy heavy fines against enterprises for pollution.... Should this set of eircumstances materialise without central action to relieve such effects (for example, by allowing price increases for pulp and paper products), it may make it impossible for the pulp and paper enterprises having limited funds at their disposal to invest in pollution controls or, alternatively, may force some of the least costefficient enterprises to shut down if the authorities actually enforce the environmental laws. 27

It appears that prices for paper products are being allowed to rise, and it is not clear if authorities are actively enforcing environmental laws, so the assessment need not be so pessimistic.

In the post Cold War era, the scaling back of military expenditures may have catastrophic consequences for $\mathbf{s t}$.

26coalition Clean Baltic, "An Alternative Programe of Environmental Protection of the Baltic Sea (Poland)," preliminary report, Gdansk, May 1991, p. 26.

27 Turnbul1, p. 68 . 
Petersburg, as funds from Moscow shrink. There is much discussion about conversion of the military industry to civilian production, but such a transition does not come easily, even under better economic circumstances, as is being experienced in the United States. At present, the Russian record on conversion is abysmal. Conversion expert Vyacheslav Kolbin and scientist Evgeny Aleksandrov point out that the military consumes almost one-third of the G.N.P. of the Russian economy. Now, in a time when military expenditures should be curtailed, the only effect has been the destruction of armaments that have already been produced.28 Jeffrey Sachs concurred with this assessment in a recent interview, claiming that the military-industrial complex is still an economic sacred cow. As he explained,

The money spigots were opened up this summer [1992] to keep alive the military-industrial complex, the producers of the armaments and the rest of the heavy industry, despite the fact that there are no customers for these things any more.... [T] he result is that everybody is going to pay
disastrously for it....29

He goes on to say that Russia is subjecting itself, appropriately enough, to market forces, which should open up opportunities for shops, banks, hospitals, and so on. "But the pressures from the old guard to keep the old factories going has led to an incredible pressure to print money to pay

\footnotetext{
28 Aleksandrov and Rolbin, p. 18.

${ }^{29}$ Jeffrey Sachs, interview on "C.N.N. Moneylune," television broadcast, 15 October 1992.
} 
for output that nobody wants. And it seems that the industrialists are winning right now." 30

On the other hand, the military-industrial base and skilled work force provide much hope for future economic, and thus environmental, security. One environmental organization is promoting projects connected with developing environmental businesses using these assets. For example, projects are on the drawing board for converting some plants to production of water-treatment equipment. However, there are ominous signs that this potential will be lost, as some plants propose solving their problems simply by selling off equipment to foreign countries, 31 ignoring long-term gains for short-term profits.

As discussed earlier, the myth that weapons have a low per unit cost, and thus fetch large profits when exported, unfortunately persists. Aleksandrov and Kolbin claim this misconception is "...a manifestation of the same old policy of concealing military spending and a result of the artificially low prices for raw materials, metal and energy that have been arbitrarily established for the military branches." 32 If the high level of military production and its accompanying disregard for the environment continue, the prospects for change in St. Petersburg will be quashed.

${ }^{30}$ Sachs.

$31_{\text {Aleksander Aleksandrov. }}$

32 Aleksandrov and kolbin, p. 18. 
Inferior and outdated technology and inadequate expertise have already been mentioned as major stumbling blocks to a healthy environment. Nonetheless, the Chair of Latvia's Parliamentary Committee Overseeing Environment looks at the lack of technology and an environmental industry in the Soviet successor states from a positive angle:

In my opinion, our current situation presents a unique opportunity to foreign firms for investing much-needed capital in our ecological industries and to establish markets in the Baltic, Russian and other former Soviet republics, where these industries are non-existent. ${ }^{3}$

\section{Agriculture}

In the agricultural sphere, better land and waste management policies and practices are desperately needed. Over the last 10 to 15 years, the volume of fertilizers used in the Leningrad region has increased 358 , and plans are to increase mineral fertilization volume by 508 and organic fertilization by $108 .{ }^{34}$ The figures do not bode well. Improved methods of storage, transport, and application are sorely needed. Organic matter from livestock breeding should be deposited in the fields, reducing runoff into local waters and returning nutrients to the soil. 35

\section{Energy, Transport, and Waste Disposal}

With an expanding economy, fuel and energy needs will be of utmost importance to the Leningrad region. In this

33"An Interview with the Chairmen...."

34 KONSOFIN, p. 23.

35 KONSOFIN, p. 25. 
respect, proposals for a future policy are being put forward. At the "Nuclear Technologies Tomorrow" conference in St. Petersburg last September, several experts claimed that the region must turn to alternative fuels for the following reasons: first, organic fuel stocks are becoming exhausted. Second, the long distance transfer of some energy types to the area involves large in transit losses. Next, extraction costs are increasing as more remote reserves are tapped. There is also the question of harmful emissions from the burning of traditional fuels. And finally, the uncertainty and dangers surrounding nuclear power make it an unreliable source of energy. The panel went on to explore increased use of hydrogen as a fuel, in conjunction with an underground atomic energy station. ${ }^{36}$

Other alternatives are being explored. Philip Pryde of San Diego State University explains that a great many countries are building pumped storage stations for producing electricity. Inexpensive nıghttime electricity from a regularly operating plant is used to pump water uphill to an artificial reservoir. At the peak period during the day, the water is allowed to run downhill, generating more electricity. The system is less environmentally damaging than conventional generating plants: only a lower body of water, which need not be dammed, an elevation difference, and

\footnotetext{
36T. S. Dideikin, V. D. Isliamov, E. L. Petrov, V. P. Struev, Iu. $M$. Dal, and V. T. Zubov, "Erologically Pure and Safe Power Supply of the Reqion of St. Petersburg," presentation at Nuclear Society's Third Annual Scientific-Technical Conference, "Nuclear Technologies Tomorrow," st. Petersburg, Russia, 17 september 1992.
} 
an existing electricity source are needed. A pumped storage plant is planned for construction in St. Petersburg.37

Still, the area's energy agenda is unclear. The journal Coal Age reported that coal from the Kansk-Achinsk bas in in Central Siberia is mainly low quality lignite coal. Yet. this region, the country's largest lignite producing area, could become the largest coal-producing area by 2000.18 Lignite, or brown coal, is not an efficient burner, having a low calorific value. If Kansk-Achinsk is an indication, more lignite will be burned in the country's furnaces, causing greater atmospheric pollution. Matthew Sagers, in his annual review of energy output in Soviet Geography, observes that, beginning in 1989, there has been a decline in the use of the low-quality Kansk-Achinsk coal, ${ }^{39}$ so the future picture is fuzzy. Moreover, because of production distortions caused by the economic slowdown and mining strikes beginning in the late 1980 's, it is difficult to gauge precise coal trends, but lignite production seems to be holding at about 238 of overall coal production. A more positive note, however, is the fact that natural gas production has risen dramatically since the 1970 's, much more so than coal production.4"

\footnotetext{
${ }^{37}$ Pryde, Environmental Management..., pp. 61-6,2.

38 "Soviets Choose Coal slurry Over Mine-Mouth Plants," Coal Age,

${ }^{39}$ Sagers, April 1991, p. 274.

40Sagers, April 1991, pp. 272-275, and April 1992, pp. 2'3, 2'B-
} May 1986, p. 24. $259,260$. 
The danger of a nuclear power accident at Sosnovyi Bor will remain a future concern. A. M. Petrosyants, then Chair of the U.S.S.R. State Atomic Energy Commission, said in an interview one year after the Chernobyl mishap that R.B.M.K. reactor safety was no longer a looming question. He assured the public that personnel training had been greatly improved and that technical means had been used to improve reliability. "These safety measures," he claimed, "make it possible to rule out the technical possibility of another accident. Reactor safety has increased significantly, and it will be guaranteed even in the event of improper actions by personnel."41 This assessment has been corroborated by some experts in the West. 42 The safety mechanisms at Sosnovyi Bor, which successfully prevented a major accident in March 1992, may be testimony to the claims. Nonetheless, many experts claim the plant is dangerous and should be permanently shut down. The then Chair of the U.S.S.R. State Committee for Industrial and Nuclear Safety, V. M. Malyshev, for example, said at a session of the Supreme Soviet in 1989: "I would not like to jump ahead of the course of events, but in our country there is the preliminary opinion that R.B.M.K.

$4{ }^{1}$ Quoted in V. Itkin and $\mathrm{L}$. Chernenko, "Lessons of Chernobyl: Reactor Safety," Sovetskaia Rossiia, 26 April 1987: 2; Current Digest of the Soviet Press, 17 (1987), pp. 5, 9, 20.

42 Torry Rogers, comments at conference "Environmental security After Communism," Ottawa, Ontario, 27 February 1993. 
reactors should be totally removed from operation, probably by the year $2000 . " 43$

Although the Russian Ministry of Ecology will probably oppose new nuclear energy plant construction, additions and upgrades to existing plants will, in all likelihood, be acceptable, and it appears this will precisely be the case at Sosnovyi Bor. At a press conference of the Russian Ministry of Atomic Energy and Industry in January 1993, it was announced that the Sosnovyi Bor plant would receive a new power unit. Although the announcement was short on details, it seems as if the first reactor at the site, which must be decommissioned in the near future because of its age, will be replaced. 44 So, despite the concerns of many residents and experts in st. Petersburg, the Sosnovyi Bor facility will not be shut down or phased out. Nonetheless, representatives from the Sosnovyi Bor and Leningrad oblast Soviets recently stressed that no future building of atomic power facilities could take place without the cooperation and approval of local authorities and populations and without answering the question of radioactive waste processjing and storage. 4 s

\footnotetext{
43 Quoted in Lavrov, p. 488.
}

44 Marples.

45v. K. Zasukha, V. A. Kirpichnikov, v. N. Klimov, A. G. Petruv, Iu. B. Petrov, and V. E. Sabinin, "Vzaimodeistvie spetsialistov, mestnykh organov vlasti i obshchestvennosti pri priniatii resheniia o stroitel'stve atomnykh energetichegkikh blokov v Sankt-Peterburgskom regione," [Cooperation of Specialists, Local organs of Power, and the Public in Decision-Making Concerning Atomic Power Plant Construction $1 n$

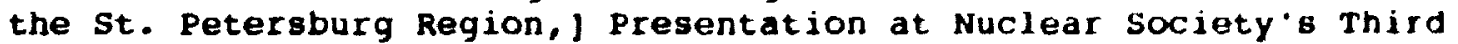
Annual Scientific-Technical Conference, "Nuclear Technologies Tomorrow," St. Petersburg, Russia, 16 september 1992. 
Another area of extreme danger is in the transportation sector. While the region relies heavily on public transportation, it can be assumed that with greater growth of the consumer industry comes an increase in demand for private automobiles, among the most environmentally damaging products. The effects of transportation on the city's atmosphere have already been noted. In addition, a rise in solid and toxic wastes can be expected, with the discarding of used tires, oil, transmission fluid, and other toxic substances, as well as parts and the automobiles themselves. Thus, the need for a new hazardous waste disposal plant, as we:. 1 as recycling programs and landfills, is apparent. st. Petersburg greatly depends on its shipping industry, and in that context there are proposals to build a new port for the city. Comparisons of the project to the genesis of the dam are numerous, as the pro-port side has begun pushing through its agenda. Officials, including the President of Petrosoviet's Environmental Commission, have made assurances that environmental concerns will be taken into account, yet even as the government was readying to sign the documents last spring to commence work, the Academy of Sciences had not even completed its evaluation of the impact of the project. In addition, a director of construction has already been named. 46

46T. Artemova, "Direktor uzhe est." " There is Already a Director, ] Vechernii Peterburg, 23 May 1992, p. 1. 
The city is ill-prepared to face the increasing waste burdens it will encounter. In the late 1980's, U.S. experts in waste disposal noted that, without international dialogue, Soviet plans to make state-of-the-art improvements in wasteburning facilities could be out-dated even prior to implementation, since vast improvements were already on-line elsewhere in the world.47

Toxic industrial wastes, the most hazardous, present St. Petersburg with a dangerous situation. Solving the hazardous waste disposal problem at Krasnyi Bor was deemed the most urgent project in the entire region, according to the Finnish Ministry of Environment's priority program.48

Current concerns with hazardous waste are as follows: - Some hazardous wastes are discharged into sewers and surface waters because of the absence of modern collection and treatment facilities

Waste water treatment plants are inhibited from functioning properly because of the presence of hazardous wastes, which remain, to a great extent, stable throughout purification processes

Gases from incinerated wastes are not cleaned, causing unpredictable atmospheric pollution

${ }^{47}$ Robert E. Blattert, "To Russia with Sludge: Americans See Soviet Waste," The Management of World Wastes, September 19\&B, p. ", .

48 Ministry of the Environment of Finland, p. 103. 
- Ground water levels in the area of the site are fairly high, and samples of the water show severe chemical pollution. 49

\section{FUUDING ATD AID}

There can be no question that more money must be spent on environmental problems. Research seems to suggest that approximately 28 of a country's G.N.P. must be spent for stabilizing ecological conditions. Yet, according to his statement to the Congress of People's Deputies in 1989, Iablokov claimed that, in order to improve the country's environment, no less than 58 is needed. The U.S.S.R. was spending at that time, he claims, only around 18.50

In the past, Leningrad was able to obtain relatively substantial funding from the central authorities for environmental protection. Like Moscow, Leningrad not only carried considerable domestic political significance, but also served propaganda needs as one of the main points of entry for foreign visitors. ${ }^{51}$ with little money at the center and propaganda needs much diminished in the post-communist era, it is unlikely this funding will continue.

For this reason, as well as the fact that Russia is wanting in the areas of technology and expertise, there will be an enormous need for international help. In this regard, Russia generally and St. Petersburg particularly are already

\footnotetext{
49 Ministry of the Environment of Finland, p. 80.

50 cited in Lavrov, p. 492.

51Jancar, p. 197.
} 
establishing contacts with and receiving aid from foreign sources, especially the Scandinavian states. Finland and Sweden have taken a particular interest in environmental affairs. Indeed, these countries have a big environmental stake in St. Petersburg's welfare; Brock University's Juris Dreifelds maintains that the Scandinavian countries receive 14 times more benefit in investing in the environment in the former socialist states along the Baltic Sea than in domestic investment.52 In Finland, for instance, the Soviet contribution to sulfur pollution in the country was greater than that from domestic sources in the 1980 's, with 148 of the Soviet sulfur contribution coming from the Leningrad region. Similarly, the country receives nitrogen pollution from the former U.S.S.R. in about equal amounts to that produced domestically. And since the waters of the Gulf of Finland circulate in a counter-clockwise direction, the Scandinavian countries pick up pollutants from the southern and eastern coasts, 53 i.e., from St. Petersburg, the Leningrad Oblast, and Estonia.

In 1991, the Government of Finland, in conjunction with authorities of the Soviet Union, began preparing a list of priority projects to be targeted for environmental clean-up, with cooperation between domestic and foreign sc rces. The plan targets sites in Karelia, the Leningrad oblast, st.

52Juris Dreifelds, "Baltics: The Case of Latvia," presentation at conference "Environmental Security After Communism," Ottawa, Ontarin, 27 February 1993.

53 Ministry of the Environment of Finland, pp. 10-12, 14-16, 18 . 
Petersburg, and Estonia. The study notes that a large sum of money for the priority projects must come from Western sources, but that non-money aid could take the form of technical consulting, contractina, machinery trade, or training, while direct financing is expected from international development banks and other financial corporations. Still, the largest sum must come from the local units themselves, 54 and herein lie many problems. "Paying back loans and giving guarantees," the report states, "will be the biggest problem when starting an individual project or the whole programme." The local political units, including St. Petersburg, have "no chance," according to the report, of repaying foreign loans. Some options for other forms of repayment include selling tourist facilities, state financing, and penalizing industrial polluters in foreign currency.55 Yet, as noted, even higher political bodies have scant foreign currency, and industry receives little payment in hard currency. St. Petersburg is in a particular bind, owing to its many environmental needs, low foreign currency income, and few natural resources with which to barter.56 Along these lines, according to another report, ... in the foreseeable future environmental projects in St. Petersburg can be only launched if the donor agrees to pay all the hard-currency expenses and accepts... payment in rubles from the local sources. As the convertibility of [sic] ruble remains a far

\footnotetext{
54 Ministry of the Environment of Finland, p. $x$.

55 ministry of the Environment of Finland, p. $x$.

56 ministry of the Environment of Finland, p. $x$.
} 
cry, this means that...local funds can only be used to purchase manpower and some raw materials and equipment. 57

Despite the dire need for outside aid, to date, the record of lending institutions, like the International Monetary Fund, is not good. In 1992, for example, the I.M.F. did not have a single permanent monetary specialist in place in Russia. In August, strangely enough, they gave the Russian monetary policy a clean bill of health, apparently ignorant of the real situation. A day after the I.M.F. announcement, the ruble collapsed 208.58 This belies ignorance and seems to indicate lack of interest, and does not bode well for future aid: if one of the world's top lenders is so unmotivated, then smaller bodies will probably be no more inclined to bring aid to the country.

Barter will, in all likelihood, be a prime form of exchange in acquiring environmental aid from the outside. In a speech given in Helsinki in December 1991, St. Petersburg Mayor Anatolii Sobchak said that his city could pay for food with oil and scrap metal.59 Mildred Turnbull notes that, in the case of the pulp and paper industry, which has been hindered by its ministry in obtaining non-domestic technology, opportunities exist to exchange timber, wood products, or pulp for foreign technologies. 50 Likewise, the

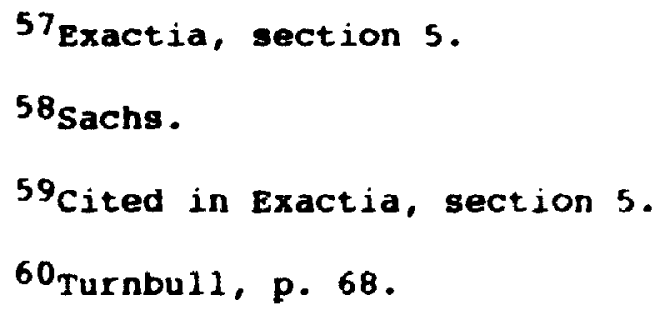


city's ability to sell and rent land can be used to deal with foreign firms, as Lenvodakanal, the region's water authority, hoped to do with its French partner, albeit with less controversy, as already explored.

Greater private foreign investment has both its light and dark sides. Technology and know-how in the environmental field are valuable assets that foreign firms can bring to the St. Petersburg business scene. On the other hand, the city must be wary of unscrupulous businesses or those merely looking at a bottom line that does not always make ecological sense. For instance, General Electric made a $\$ 150$ million deal in Hungary to upgrade incandescent light bulb factories. If the deal had been for fluorescent bulbs instead, the Hungarian government would have saved billions of dollars on building new coal-fired power plants. While the deal was a sound one for G.E., its ecological sense must be questioned.61 In its desperation for foreign aid, Russia is likewise prone to short-sighted investment, as demonstrated by the Lenvodakanal controversy.

Other environmental programs for the region are on the drawing board. Coalition Clean Baltic has suggested creating supranational programs for the former Baltic socialist states to aid them in achieving environmental aims, with the help of credits from international financial organizations. They further suggest setting up Baltic reconstruction and

${ }^{61}$ French, "Green Revolutions...." pp. 41-42. 
development banks connected with joint projects for environmental protection. 62

Another interesting new local project is the Center for Citizen's Initiatives, a branch of a relatively large organization called the Center for U.S.-U.S.S.R. Initiatives, which was established some 10 years ago. One of its departments deals with environmental problems. Early in 1992, a corresponding department at their center in St. Petersburg was established. According to the Director, Aleksandr Aleksandrov, one of their focuses is the problem of water quality in St. Petersburg. With the cooperation of their U.S. American partner in San Francisco, they intend to establish a committee of experts on the subject. From there, they will try to evaluate water management in the city and provide aid to other Russian entities, like city authorities and other governmental organizations who are involved in the area. The approach is two-pronged, focusing on providing aid to related groups, but also on monitoring and control, because of the widespread misuse of authority on projects.t.

\section{SOCIO-POLITICAL PROSPECTS}

Environmental education must become a priority. As stated earlier, education and upbringing in the environmental field have been fraught with ignorance and misconception. So serious are the ramifications that one report on environment. in the Leningrad region bluntly reads: "It is vital to

${ }^{62}$ Coalition clean Baltic, p, p. 18.

63 Aleksander Aleksandrov. 
understand that the current socio-ecological condition has resulted from the low standards in general culture, environmental education, upbringing, and behavior."54 Ushering in a better environment means changing the standards.

Recently, an educational project entitled the Baltic University was launched, involving 9 countries of the Baltic region, including Russia. One course involving the ecological situation of the Baltic is broadcast via television, with students able to respond and ask questions via telex.65 Othe educational cooperation schemes with outside institutions would be immensely useful for general educational purposes, and as a spin-off would help tap sources of foreign expertise in the field for concrete problem-solving.

\section{Bcological Administration}

Not unlike economic changes, the political change engendered by the collapse of the Soviet Union portends both good and bad for the environment. As DeBardeleben notes, "Extreme decentralization makes it as hard for governments to act effectively as extreme centralization does." 66

\footnotetext{
${ }^{64}$ Leningradskii nauchnyi tsentr, p. 9,

65"Eco Notes: Ecological Education Project, "Eco Logic. (Quarterly publication of the Environmental Protection Club of Latvia Elpa, ) January 1992.

66 Joan DeBardeleben, comments at conference "Environmental Security After Communism," Ottawa, Ontario, 27 February 1993.
} 
On the positive side, the problems we have seen with central control of the environment may be overcume. However, as localities face increasing economic pressures, they may have to sacrifice environmental health for economic growth. Local officials can criticize central authorities for their environmental record, but when they themselves hold the purse-strings and make the decisions, and revenue in the form of taxes can be gathered only from local enterprises and workers, then hard reality will make for difficult choices."' Cases of municipalities taking a stance against pro-ecology forces are already on record. For instance, in the town of Kirishi, located in the Leningrad region, activists fighting to halt emissions from the local biochemical feed protein plant confronted not only the usually unfriendly economic ministry, in this case the Ministry of the Biochemical Industry, but also the City Soviet Executive Committee.., On the other hand, cases exist to tne contrary, which shows that local authorities are not necessarily intimidated by economics. Izvestila reported in 1985 that the Leningrad Battery plant had been exceeding allowable norms for atmospheric emissions by 7 fold. As pressure to clean up the air increased, managers resisted and claimed that nothing could be done because of the importance of the batteries produced there. In the end, the inspectors trying to shut down a section of the factory won, and managers had to go

${ }^{67}$ DeBardeleben, "The New Politics..., pp. 10, 21. ${ }^{68}$ DeBardeleben, "The New Politics...." p. 10 . 
through several revisions of plans to modernize in order to meet the inspectors requirements.69 The outcome at the Priozersk mill on Ladoga also bolsters the case for local authority acting against simple short-term economic interests.

Beginning in 1991, polluting factories were to have been fined under local jurisdiction, with 858 of the money going to local bodies for pollution control. Yet some of the ridin culprits, like the steel and chemical industries, were to be exempt. ${ }^{70}$ It is not clear if the legislation has actually been implemented. What is more, as mentioned earlier, if fines go into local coffers, local bodies may actually benefit from pollution, and there is, as a result, a disincentive for real environmental safeguarding.

Another possible drawback is, at least in the case of smaller towns, complete subordination of the town and conditions there to the will of one major enterprise. Iocal groups cannot easily oppose the town's employer, as was witnessed in Priozersk. In this case, success of local initiatives will depend on help from outside the area, meaning links with national and international groups are important. ${ }^{71}$

There are other :- oblems that may arise with the devolution of power from the center. With political power

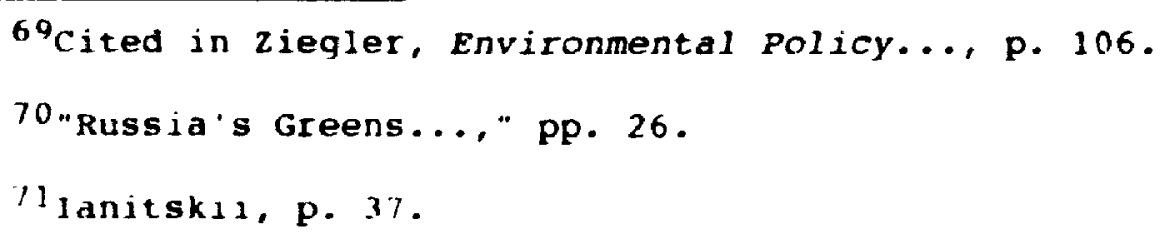


amassed in local hands, the possibility of bzibery and corruption is much more real. In addition, the so-called NIMBY, or "not in my back yard" syndrome will become more apparent, 72 as local leaders will feel the pressures from citizens much more acutely than former leaders at the center did. In this manner, local leaders can be handicapped when exploring solutions to environmental problems. On the other hand, the same NIMBY phenomenon will be a useful tool against polluting enterprises and the like, both those currently operating and those slated for future construction.

In the current and, more than likely, future political chaos, the environment may suffer. Leaving the economic ramifications aside, it is possible that decentralization will aggravate conditions, as a unitary environmental policy is abandoned. 73 The patch-work of policies to follow may be woven with contradictions, different emphases and priorities, and Iimited and scattered funding sources. This seems to be the case in st. Petersburg.

Decision-making in the city is carried out on a case by case basis, with little regard for a unified policy. Furthermore, while the old system of excessive numbers of units carrying out redundant or irrelevint tasks is gradually being replaced, it tends to reappear in new forms with the current ongoing reorganizations. ${ }^{74}$

\footnotetext{
${ }^{72}$ Dreifelds.

${ }^{73} \mathrm{Gel}$ 'vanovskil and Trofimova, p. 13'.

${ }^{74}$ Exactia, section 3.2 .
} 
Problems among the political players are numerous. First, as is clear from the previous descriptions, the responsibilities of the different organizations are either unclear or overlapping. Various bodies are subordinated to more than one superior, sometimes to both national and local authority. In the case of Lenkompriroda, for example, a dispute arose following the election of a Chairperson in 1991, whom City Council approved but the Regional Council opposed. ${ }^{75}$ There is also a power struggle between the City Council and the Mayor's office, which arose with Sobchak's election in June 1991. As Sobchak sought to maximize powers, the then Lensoviet fought to restrict the powers of the Mayor's Office. Although the Mayor ultimately gained the upper hand, particularly after the August 1991 coup attempt, an uneasy compromise has been struck, and each side pursues its own interests against the other. ${ }^{76}$

Internal problems are also manifold within each of the three bodies. While lack of funds is the main restrictive factor, City Council is also limited by a lack of expertise and, in the view of a Finnish firm, genuine concern for the environment among its members. 77 Petrosoviet Ecological Commission Member Sergei Pomagaev claims that the commission has degenerated since its inception and is plagued with problems. He asserts that those working sincerely on

\footnotetext{
${ }^{75}$ Exactia, section 3.2 .1 .

76 Exactia, section 2.1 .

77 Exactia, section 3.2.2.
} 
environmental problems have been nudged out of the commission, while economic concerns, especially those regarding the city's military-industrial complex, take precedence over ecological concerns. In a speech before city Council, he blasted the Ecological Commission for these and other shortcomings, accusing it of neglecting to act against polluting enterprises and failing to see the link between economic and ecological interests. He further claimed that, organizationally, the commission has no written plan, and thus cannot achieve its goals, while city Council itself does not know what it expects of the commission, leaving it to flounder. Pomagaev goes on to say that the present political structure inhibits effective action because of the absence of political parties and competing interests in the City Council and Ecological Commission. ${ }^{78}$ Joan DeBardeieben acknowiedges that the formation of political parties is in its infancy, and that a developed party system will allow for more organized debate of issues, including environmental issues." Petrosoviet itself is too large to be efficiently run, with Council sessions often nothing more than banter. In attempting to mend the problem, various proposals, ranging from creating a separate standing committee, to instituting an additional "small soviet," to reducing the size of the Petrosoviet itself are being explored. But there are fears the moves could weaken the Council, strengthening the Mayor's

78 pomagaev.

${ }^{79}$ DeBardeleben, "The New Politics...," p. 22. 
political hand. Moreover, members have been accused of acting on the basis of political devotions rather than political expertise. 80

Mayor Sobchak is seen by some to have made an about-face on environmental issues like the dam, which he previously argued against but toward which he now has taken a more conciliatory stance, even appointing a former boss of the dam project as an economic advisor. Stadnitskii accuses the Mayor of acting, to a large degree, in the interest of industrial enterprises. ${ }^{81}$ If this is so, it is perhaps as a result of the difficult choices that must be made between ecological and short-term economic goals, which seems to be the case as well with the Petrosoviet's Ecological Commission.

As for Lenkompriroda, many are suspicicus of the comnittee because of its leaders traditional conservative thinking. Indeed, the organization maintains close ties wj.th government bureaucrats, making it a haven for former nomenklatura.82 Stadnitskii claims that, in some of its functions, for instance disbursing permits or levying fees, Lenkompriroda acts selectively or with no regard to the environment at all. Otherwise, he says, the process would

\footnotetext{
${ }^{80}$ Exactia, section 2.2 .

${ }^{81}$ stadnitskii.

${ }^{82}$ Exactia, section 3.2.1.
} 
snowball and too many factories and resource users would have to be closed, fined, or otherwise punished. 83

Greater cooperation and coordination is needed among the new environmental control bodies in the city. To avoid splintering and overlap of legislation, information collection and analysis, legal jurisdictions, etc., as was characteristic under the ministerial system, the Mayor's Office, Petrosoviet, and Lenkompriroda must establish greater Iir is and resolve the question of authority over environmental matters.

Goskompriroda, the former Soviet state Committee for Environmental Protection, had prepared a national program for environmental protection and resource use to the year 2005. Following that lead, the Executive Committees of Lensoviet and Lenoblsoviet followed the program and prepared their own programs for the same time period. However, there are fundamental problems with the programs. According to one critique:

The feasibilities of different projects are not studied and the programmes are only lists of projects which should be implemented. Is an example of this, j.t can be mentioned that the targets for the first year (1991) of the programme cannot be reached because of financing and implementation problems. 84

As already noted, the Soviet Union was a signatory to numerous conventions on environmental matters directly affecting the Leningrad region. If Russia and St. Petersburg

${ }^{83}$ Stadnitskii.

${ }^{84}$ Ministry of the Environment of Finland, p. 97. 
can meet their obligations as spelled out by the treaties, numerous areas, including the Baltic, and in particular the Gulf of Finland, will be considerably cleaner.

A new trend seems to be arising in which local

authorities give away outlying land parcels to citizens. In conditions of a poor economy, the practice seems legitimate ir. allowing people to grow their own food, not to mention the possible psychological and political benefits. However, one ecologist in St. Petersburg cautioned that the practice is fraught with problems. He claims that many of the plots are in the woods in resort or park zones, and that trees are disappearing at an alarming rate. ${ }^{85}$

\section{Environnental Law}

In the legal area, many changes must take place. According to the Finnish Ministry of environment, the most urgent changes are needed in the area of norms. "It is of common opinion," the report states,

that the norms are considered to be unrealistic and the control of them is impossible due to the lack of modern control equipment. Also the relation to financing is in many cases forgotten, which leads to situations where the construction and running costs are too high. 86

For one thing, rather than measuring pollutants by concentration at the point of discharge from the polluting source, specific allowable amounts, expressed in weight or

85stadnitskii. When in Moscow in the summer of 1992, I traveled north of the city to view small plots of land that the government was parceling among Muscovites. The landscape did appear to have been haphazardly stripped of vegetation.

86ministry of the Environment of Finland, 98. 
volume per unit time or output, must be measured.

Legislation proposing such a law has already, in fact, been drafted.87 Additionally, tax breaks and other economic incentives for pollution abatement projects and equipment will allow factories to make further moves toward appropriate environmental protection. Other measures, like appropriate punishment for industrial polluters, must be implemented and enforced.

Environmental law continues to be confusing, impotent, and outright contradictory. According to a Finnish study,

During the current period of political and economic transition the precise role of legislation is extremely difficult to define. Political disputes in the midst of deepening economic problems have undermined the impact of formal norms in a way which gives signs of a fundamental legal crisis throughout the society. The evolving environmental legislation, which is still searching its proper position, is of course particularly sensitive to negative impacts of the crisis.88

Locally, environmental law is seen as an important piece in the ecology puzzle. The Environmental Department of the Center for U.S.-U.S.S.R. Initiatives, for example, is especially trying to obtain assistance in the legal sphere from its parent organization in the United States. The organization sees environmental law as the main tool to combat industry and business, yet it has practically no experience in this field. 89

\footnotetext{
87 KONSOFIN, P. 46.

${ }^{88}$ Exactia, section 4.1 .

${ }^{89}$ Aleksander Aleksandrov.
} 
In late 1988, F. T. Morgun, first director of the newly formed Goskompriroda, announced a system of environmental laboratories throughout the R.S.F.S.R. Leningrad was to be the site of one of the labs. Turnbull acknowledges that the exact purpose of the laboratories is uncertain, but she nevertheless asserts that "The importance of these centres and their scientific subdivisions (which will be devoted to specific pollution problems generated by manufacturing] cannot be overstated...."90 One can envision spin-offs like an infusion of money, expertise, and attention. Thus, the presence of an environmental laboratory under central auspices portends well for the future local picture.

The Environnental Movenent

As is generally true throughout the country, the environmental movement in St. Petersburg is in no position to mount great pressure for change. There are several reasons for this. First, the movement is young and inexperienced. These groups have little knowledge in monitoring, selfsufficiency, or politics. In St. Petersburg, the best known and most powerful environmental N.G.O., Del'ta, was formed only in April 1987 as a group of concerned citizens opposed to the construction of the dam, 91 while the local green party, the Green Party of St. Petersburg/Leningrad oblast, was established in March 1990.92

90 Turnbul1, pp. 5, 200 (n. 23).

${ }^{91}$ rozhevnikov.

92 Gushin. 
Next, the groups tend to be poorly organized, both internally and externaliy. Internally, most environmental groups seek to avoid any vertical organizational structure. Many of the groups, therefore, consist merely of a leader and members.93 And recruitment of members is rather pell-mell, resting upon chance. Regarding Del'ta's membership, CoCoordinator Sergei Pomagaev claims it is like "...some kind of Mafioso group, or Masonic group, because we don't do...volunteer drives. It's one of the gaps in our work, because we don't deliberately try to attract new members." "14 There is thus little effort paid to recruiting via mailings, mail list exchanges, etc. In fact, so little does Del'ta pay attention to membership, that the leader himself could not give an estimation of the number of members, claiming they simply do not have a fixed number, 95 although Pomagaev puts the number at about 30.96 This number is rather small for the largest, most powerful environmental group in the city.

One also gets the impression that the groups are somewhat chaotic in their internal organization and tactics. In the view of many outsiders, especially scientists concerned with environmental problems, the environmental movement of St. Petersburg is disorganized, unprofessional, poorly informed, and not very visible.

93 Exactia, section 6.2 .

94 Pomagaev.

95 Kozhevnikov.

96 pomagaer. 
In this vain, the Center for International Environmental Cooperation's Karpov claims the movement is "...mostly emotions. It's like the anarchy in 1917, with some flagwaving... [and] emotions.... They don't know anything, they don't warit to read anything, they are only crying."97 And water specialist Dobrykh claims that, from her perspective as a scientist, she sees various groups from time to time at meetings and conferences about water and sewage tr satment. The representatives, she asserts, only parrot what has already been said and exposed by the scientists. But whereas she believes that scientists carefully evaluate the situation and determine the real priorities and dangers, the greens make noise without the necessary foundations to work from. Dobrykh cites a meeting some three years ago in which a representative from one environmental group spoke out at a conference:

He was very dynamic but he didn't understand the essence of the problem. He talked about the sludge situation and how bad that is, and blamed our leaders, but he didn't understand that this is a world-wide problem. It costs a lot of money to treat water, and then once the waste is extracted from the water, the question is what to do with it... but he didn't understand. There was nothing that could have been done at that time and the leaders were not guilty on this question.98

One of the leaders of the Green Party of St. Petersburg/Leningrad Oblast indirectly corroborates Dobrykh's observation. vladimir Gushin says the party can boast of few
${ }^{97}$ Karpov.
98 Dobrykh. 
environmental experts among its members. Nor does the group consult much with outside experts. Instead, it relies on obtaining documents intended only for government use and the like, from which it extracts the information it needs. ${ }^{90}$ Even if this unreliable information-gathering tactic fetches adequate information, without experts to analyze the data there is a gap in the organization's ability to act in an informed manner.

External organization is a related problem. For Del'ta, this is a major weakness. It has not formally registered with the government as an official organization, despite its desire and intention to do su. Pomagaev laments this status, for the group can not properly accept donations, maintain budgets and accounts, and so on. Del'ta is, he says, concentrated on action rather than organizing itself. 100

Furthermore, the environmental movement is not unified. Hilary French says that four large umbrella organizations, the Social-Ecological Union, Ecology and Peace, the Green Movement, and the Ecological Union are attempting to $l$ ink numerous local groups into a national movement.101 Yet, despite these efforts, a unified movement remains an unfulfilled dream. In talking with people representing the various groups and interests in the city, I was struck by the mistrust, misgivings, and outright conflicts anong the

${ }^{99}$ Gushin.

100 Pomagaev.

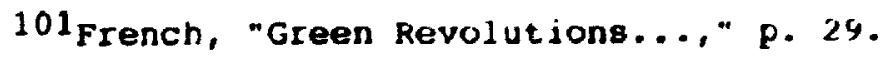


various local personalities, including those in the environmental movement, the scientific community, and politicjans.

Next, there is a severe lack of financial resources. While this may seem to be not unlike the situation as we know it in the West, there are differences here. Many of the groups lack financial policies and do not even seem to regard the raising of finances as important. 102 Again, Pomagaev admits that Del'ta has little money with which to work, yet the group does not even have a fund raising strategy with which to attempt to add to its coffers. Instead, members either give their own money when necessary or, through a network of supporters, the group seeks the use of printers, copiers, and the like, as well as free expertise, as needed. 103 Likewise, the Green Party collects its funds from membership dues and has no fundraising or financial department. 104

The decentralization process is, it seems, having little effect on the practical work of green groups in the area. Neither Del'ta nor the Green Party reported any significant repercussions for their groups since the breakup of the Soviet Union. ${ }^{105}$

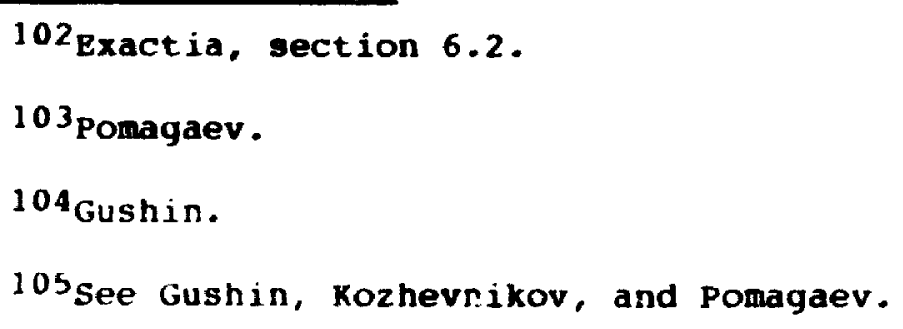


A good sign is that there is much interest in environmental issues among the populace. But although 878 of the country's residents polled claimed that a healthy environment is a priority, only 648 of Leningraders thought so. 106 Just how opinion can translate into positive action or pressure on the government is not clear, however, particularly given the dismal economic outlook.

It is also encouraging that independent environmental groups are emerging in larger and larger numbers. As the movement matures, it can overcome these shortcomings and take on a more active and legitimate role in environmental protection. Alre y some of these non-governmental groups have achieved successes in the environmental field, and in other former socialist countries the role of N.G.O.'s has had a positive impact. 107 St. Petersburg's Green Party currently claims a one in three success rate concerning the projects it focuses on. 108

\section{MATURAT RESOURCES}

The area's lakes and rivers, land, and air are poisoned and show few signs of improvement. Due to toxic substances in fertilizers, pesticide use, and pollutants received from the atmosphere, soil pollution in the area is at the critical stage, with much of the soil having lost its natural

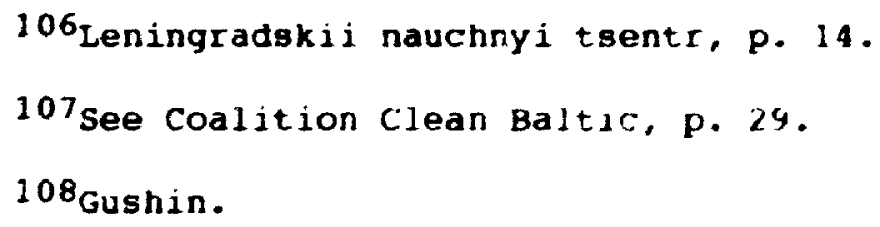


properties.10' Further increases in soil degradation are seen. At this point, even if further contamination were to cease, soils in the city would continue passing on their polluted stock to the ambient air and water for generations. 110

Most experts agree that the biggest environmental problem in St. Petersburg is the water. At the heart of the problem is a planning system that allowed a massive industrial and agricultural build up within fragile water ecosystems. And the practice continues. Despite the degradation of water reserves, new enterprises are being constructed in a number of districts where the situation has already been made critical by the concentration of industry.11: without a doubt, a long-term policy on industrial and agricultural development in the region's water basins is needed.

Despite the numerous measures taken over the years to protect them, Lake Ladoga and Nevskii Inlet in particular remain problem areas. So severe are the problems with Iake Ladoga that, in 1989, the Leningrad Environmental Pruiection Comnittee concluded that the deterioration of the lake "...had taken on a permanent character."112 Around that same time, the Geographical Institute of the U.S.S.R. Academy of

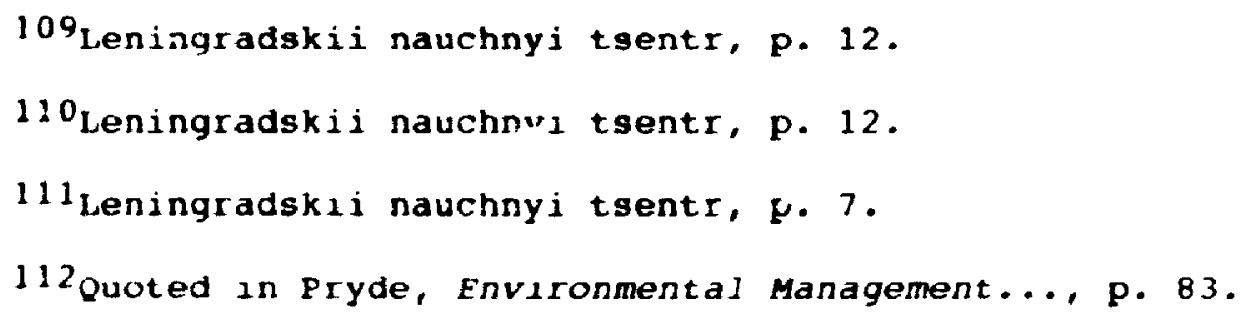


Sciences placed the lake in its "crisis situation" category of environmental analysis. This means that it has undergone considerable alteration and would require hundreds of years free of human pressures to recover to its original state.ll: Interestingly, the city of $\mathrm{st}$. Petersburg draws its water from the Neva at points upstream from its own sewage plants, but downstream from other towns also dumping into the Neva.114 One rather frightening prospect for the city is the possible ramifications of the greenhouse effect. If, indeed, ocean levels rise due to increasing global temperatures, then St. Petersburg will be devastated. As mentioned earlier, the city has historically suffered greatly from flooding. But the dam is intended as a defense against periodic long waves, not gradual and permanent $r$ ising of water levels. Much of the city is no more than 1.2 to 3 meters above sea level and, with its 60 odd rivers, channels, and canals,115 a rise in water levels would spell disaster.

This chapter has balanced the positive aspects of $\mathrm{St}$. Petersburg's ecological future with the negative. Witt the prospect of outside help, a shift toward natural gas use, improvements at the Sosnovyi Bor nuclear facility, possible resolution of the dam question, and increased public activism, the major problems in the area seem to be less

113 Bor is Ivanovich Rochurov, "Na puti k sozdanizu ekologleheshroi karti SSSR," IOn the path to Creating an Ecologucal Map of the: U.S.S.R., ) Priroda, 8 (August 1989), pp. 13-14.

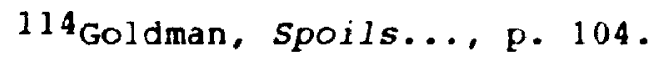

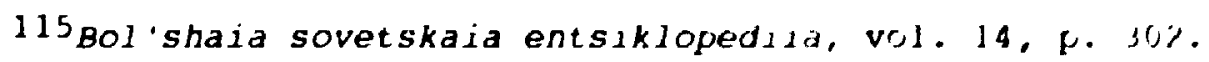




\begin{abstract}
daunting. Indeed, for these and other reasons, there is justificaiion for some optimism. Yet, the shadow of larger, systemic problems is cast over the entire picture. The overriding concerns of the economy and the political situation do not impart any near-term promise.
\end{abstract}




\section{CONCLUSION}

The starting points of environmental disruption in Leningrad/St. Petersburg and the Soviet Union, from the economic mechanism, to the laws, political structure, and agricultural needs, are, for the most part, much different from those that we know in the west. Yet, the same symptoms of industrialization that have plagued the capitalist world, like dirty air from factory smoke and car exhaust, poisoned water from sewage and agricultural run-off, erosion of land strijped of its vegetation, and radioactive contamination in the air, water, and land, can no longer be hidden within the borders of the former U.S.S.R. The era of glasnost brought with it greater opportunities to explore the ecological situation in the Soviet Union. It is apparent that, despite the decades of official Soviet proclamations to the contrary, there is indeed cause for concern about the state of the environment in the former U.S.S.R.

St. Petersburg fits into the overall picture of environmental misuse the entire country shared under the Soviet system. Nonetheless, its unique setting, from its northerly location and rich water and forest resources, to its historical role as a center for the military-industrial complex, has determined its environmental record.

That same unique character means St. Petersburg's effurts to address the environmental discord in the region 
must take a unique tack. With the end of the cold war and decentralization of the economy, opportunities for economic conversion of the area's heavy industry are presenting themselves. Furthermore, the city's location as the window on Europe and its beautiful architecture and surroundings give it a special advantage should it decide to move into the more environmentally friendly tourism industry. The inflow of foreign money from tourists and businesses hoping to capitalize on the new industry will give the city badly needed funds for improvements.

Nonetheless, despite all of potential, the city is in a poor position to take care of its environmental problems in the near-term. Military conversion does not come easily even in better economic times; the United States is a case in point. And the city, like the rest of the country, is crippled by an economy on the brink of disaster, with poor near-term prospects to meliorate it. What is more, the political instability at the center is further impeding environmental efforts. Although decentralization of political and economic power has presented the opportunity to redress the ills that the command economy wrought on the area, they have brought with them new problems. In some cases, the new situation may even be worse, at least in the short term and under such difficult conditions. Moreover, the local political arrangement with regard to environmental management is fraught with inconsistencies, conflicts, and redundancies. The economic and political woes are scaring 
outside investors, complicating internal environmental efforts, and stifling industry from moving to cleaner production, to name just a few of the repercussions.

Add these to the city's hard currency woes, the overall state of industry in the area, and foreseeably increasing public ecological apathy, and the pessimism rises. Moreover, the problems go well beyond the ability of this paper to define them. When one walks down Nevskii Prospekt and sees the filth covering the street, sidewalks and buildings and can barely speak above the din of noisy traffic; when one takes a trip to the coast along the Neva Inlet, where thousands of tourists gather every summer, and sees every manner of scrap metal, rusted cables, and other discarded materials littering public beaches for as far as the eye can see; or when one boils and filters the drinking water and still observes and tastes its impurities, one is overwhelmed. The senses are constantly bombarded by the deteriorated state of the local environment. Even given sufficient resources to correct the problems, one questions where the process would even begin.

The only hope out of the ecological quagmire lies in the long-term. The aid coming from the scandinavian countries, as well as the growing awareness of a long-stifled and ignorant local populace are positive signs. Still, not surprisingly, the environment is inextricably linked to economic well-being, so until the country and the city fird 
their way out of the economic crisis, even the positive developments can not take hold and flourish.

In 1889, Anton Chekhov wrote with great foresight in his play, "The Wood Demon":

By all means cut timber if you really need it, but it's time we stopped ruining the forests.... Man has been granted reason and the power to create, so that he can add to what he's been given. But up to now he hasn't been a creator, only a destroyer. Forests keep disappearing, rivers dry up, wild life's become extinct, the climate's ruined and the land grows poorer and uglier every day. ... [W] hen I walk past our village woodlands which I've saved from the axe or hear the rustle of my own saplings. planted with these hands, I feel that I too have some slight control over the climate and that if man is happy a thousand years from now $I$ ' 11 have done a bit towards it myself.1

The passage portends both great optimism and pessimism. Clearly, the Russian psyche has been attuned to the consequences of human activity on the natural environment for some time. Being a creator is the path to living in harmony with nature. On the other hand, this passage could have been written today; the words have gone unheeded for 100 years. In St. Petersburg, the forests are disappearing, wildlife is becoming extinct, the climate is changing, and the land is growing poorer and getting uglier. Yet, even if the present generation is aware of all this, for the most part it is helpless to save trees from the axe or plant its own saplings.

\footnotetext{
IAnton Chekhov, "The wood Demon," The oxford Chekhov, vo1. 3. trans. and ed. Ronald Hingley, (London; New York; Toronto: Oxford University Press, 1964), p. 217.
} 


\section{BIBLIOGRAPHY}

Aleksandrov, Yevgeny and Vyacheslav Kolbin. "The Country's Economy is Buried Under Piles of Weapons." Izvestila. 16 June 1992: 3; Current Digest of the Soviet Press. $24(1992): 18$.

Aleksandrov, Aleksander. Personal interview. 12 June 1992, St. Petersburg, Russia.

Artemova, T. "Direktor uzhe est"." [There is Already a Director.] Vechernii Peterburg. 23 May 1992: 1.

Blattert, Robert E. "To Russia With Sludge: Americans See Soviet Waste." The Management of World Wastes. September 1988: 58-59.

Bodnaruk, Nikolai. "Trudnoe proshchanie s proshlym." [A Difficult Fareweli to the Past.] Izvestiia. 25 April 1987: 3 .

Bol'shaia sovetskaia entsiklopediia. [The Great Soviet Encyclopedia.] Third Edition. Moscow: "Soviet Encyclopedia" Publishing House, 1973.

Bondaiev, Iurii. Literaturnaia gazeta. 2 July 1986: 4; Current Digest of the Soviet Press. 32 (1986): 8-10.

Braden, Kathleen E. "Environmental Issues in Soviet Forest Management." Soviet Geography. June 1988: 599-607.

Bublik, Iu. "Safety and Power: How Atomic Power Stations Should Develop." Sovetskaia Rossiia. 30 April 1987: 3; Current Digest of the Soviet Press. 17 (1987): 5 .

Bush, Keith. "Environmental Problems in the U.S.S.R." Problems of Communism. July-August 1972: 21-31.

Bush, Keith. "The Soviet Response to Environmental Disruption." Environmental Deterioration in the Soviet Union and Eastern Europe. Ed. Ivan Volgyes. New York, London: Praeger Publishers, 1974.

Chekhov, Anton. "The Wood Demon." The Oxford Chekhov. Vol. 3. Trans and ed. Ronald Hingley. London, New York, Toronto: Oxford University Press, 1964.

Chulaki, Mikhail. "Once More About the Value of Openness." Literaturnaia gazeta. 25 March 1987: 10; Current Digest of the Soviet Press. 14 (1987): 7 . 
Coalition Clean Baltic. "An Alternative Programme of Environmental Protection of the Baltic Sea (Poland)." Preliminary Report. Gdansk, May 1991.

DeBardeleben, Joan. Comments at conference "Environmental Security After Communism." Ottawa, Ontario. 27 February 1993.

DeBardeleben, Joan. The Environment and Marxism-Leninism: The Soviet and East German Experience. Boulder, Colorado: Westview Press, 1985.

DeBardeleben, Joan. "The New Politics in the U.S.S.R.: The Case of the Environment." Paper presented to the IVth World Congress for Soviet and East European Studies, Harrogate, England, 21-26 July 1990.

Dideikin, T. S., V. D. Isliamov, E. L. Petrov, V. P. Struev, Iu. M. Dal, and V. T. Zubov. "Ecologically Pure and Safe Power Supply of the Region of St. Petersburg." Presentation at Nuclear Society's Third Annual Scientific-Technical Conference, "Nuclear Technologies Tomorrow." St. Petersburg, Russia. 17 September 1992.

Dobrykh, Iiana. Personal interview. 26 March 1992, St. Petersburg, Russia.

Dreifelds, Juris. "Baltics: The Case of Latvia." Presentation at conference "Environmental Security After Communism." Ottawa, Ontario. 27 February 1993.

Echikson, William. "Hostile Neighbors Find Common Ground in Fighting Pollution." Christian Science Monitor. 18 November 1987: 8 .

"Eco Notes: Ecological Education Project." Eco Logic. (Quarterly publication of the Environmental Protection Club of Latvia Elpa.) January 1992.

"Ekologicheskaia karta Leningradskoi Oblasti." [Ecological Map of the Leningrad Oblast.] Leningrad: Gortekhprogress (Engineering Center of the Executive Committee of Leningrad City Council), 1990.

Ekologicheskaia Kommissiia. [Ecological Commission.] "Osnovnye shagi $v$ oblasti okhrany okruzhaiushchei sredy Leningrada." [Fundamental Steps for Protection of Nature in the Leningrad Oblast.) (Preliminary report.) 1991.

Engels, Frederich. Dialectics of Nature. Trans. and ed. Clemens Dutt. New York: International Publishers, 1940 . 
Exactia, Ltd. "Administrative, Financial and Political Preconditions for the Protection of Environment in st. Petersburg." Interim Draft Report to the Finnish Ministry of Environment, January 1992.

Ezhelev, A. "Eshche raz o dambe." (Once Again About the Dam.J Izvestila. 22 February 1987: 6.

Ezhelev, A. "V odnoi lodke: o tom, kak utverzhdaetsia novoe myshlenie na slovakh i na dele." In One Boat: How the New Way of Thinking is Being Establishzd in Words and Deeds.] Izvestila. 1 August 1987: 3 .

Ezhelev, A. "Komu urok?" [A Lesson for Whom?] Izvestiia. 27 March 1987: 6.

Ezhelev, A. "Urok ne vprok." [The Lesson Is of No Use.] Izvestila. 9 April 1987: 6.

Feshbach, Murray. "Global Environmental Security and ne Post-Communist Region." Presentation at conferer ze "Environmental Security After Communism." Ottar . Ontario. 26 February 1993.

Frantsen, O. "On the Most Vital Question in the Socii? Sphere: Formula for Health." Pravda. 13 Apris i987: 3; Current Digest of the Soviet Press. 15 (1987.: 19.

French, Hilary F. "Green Revolutions: Environmental Reconstruction in Eastern Europe and the Soviet Union." Worldwatch Paper 99, Worldwatch Institute, November 1990 .

French, Hilary F. "Industrial Wasteland." World Watch. November/December 1988: 21-30.

Gel'vanovskii, Mikhail and Irina Trofimova. "Ekologiia i resursosberezhenie: nashi problemy i zarubezhnyi opyt." [Ecology and Resource Conservation: oux problems and the Foreign Experience.] Mirovaia ekonomika i mezhdunarodnye otnoshenila. 12 (1991): 126-137.

Giulietto, Chiesa. L'Unita. 27 May 1986: 4; Foreign Broadcast Information Service. 5 June 1986: R2-R6.

Goldman, Marshall. Foreword. The Destruction of Nature in the Soviet Union. Boris Komarov. Trans. Michel Vale and Joe Hollander. White Plains, NY: M. E. Sharpe, Inc.. 1980.

Goldman, Marshall I. "Pollution in the Soviet Union: The Growth of Environmentalism and Its Consequences." Soviet Social Problems. Ed. Jories, Connor, and Powell. 
Boulder; San Francisco; and Oxford: Westview Press, 1991.

Goldman, Marshall I. The Spoils of Progress: Environmental Pollution in the Soviet Union. Cambridge, Massachusetts and London: M.I.T. Press, 1972.

Gosudarstvennyi Komitet SSSR Po Statistike. [U.S.S.R. State Cormittee for Statistics.] Okhrana okruzhaiushchei sredy i ratsional noe ispol zovanie prirodnykh resursov V SSSR: statisticheskii sbornik. [Protection of the Environment and Rational Use of Environmental Resources in the U.S.S.R.: Statistical Handbook.] Moscow: 1989.

Graham, Loren R. "Soviet Science Needs Dissent." The Washington Post. 15 June 1986: F5.

Green, Fitzhugh. "The Amerikanskis Are Coming." E.P.A. Journal. January/February 1986: 21-22.

Gregory, Paul R. and Robert C. Stuart. Soviet Economic Structure and Performance. New York: Harper and Row, 1986.

Grigor'ev, D. "Zhurnalisty okruzhili reaktor." [Journalists Encircled the Reactor.] Vechernii Peterburg. 25 March 1992: 1 .

Grin'ko, Iu. "Burazhnyi bum co znakom 'minus." [Paper Boom with a Minus Sign.] Izvestiia. 5 February 1988: 1.

Gushin, Vladimir A. Personal interview. 26 June 1992, st. Petersburg, Russia.

Gustafson, Thane. Reform in Soviet Politics: Lessons of Recent Policies on Land and Water. Cambridge, Massachusetts; New York; and Melbourne: Cambridge University Press, 1981.

Hedlund, Stefan. Crisis in Soviet Agriculture? Doctoral dissertation. Lund, Sweden: University of Lund, 1983.

Iablokov, A. Personal correspondence to Petr Kozhevnikov. 10 June 1992.

Iablokov, A., A. Monin, Iu. Polyansky, and S. Zalygin. "Does the President Need the Scientists? Why G. I. Marchuk, President of the U.S.S.R. Acadeny of Sciences, Disagrees With the Conclusions of the Expert Scientific Review of the Leningrad Dike." Izvestiia. 7 August 1990: 3; Current Digest of the Soviet Press. 32 (1990): 24 .

Ianitskii, Oleg. "Ekologicheskie dvizheniia na Vostoke i 2apade: skhodstvo i razlichiia." [Ecolcgical Movenents 
in the East and the West: Similarity and Differences.] Mirovaia ekonomika i mezhdunarodnye otnosheniia. 4 (1991): $32-47$.

Ilin, M. New Russia's primer: the story of the five-year plan. Trans. George $S$. Counts and Nucia $P$. Lodge. Cambridge, Massachusetts: The Riverside Press, ' 11.

"In the Politburo of the C.P.S.U. Central Comnittee." Pravda. 18 April 1987: 1; Current Digest of the Soviet Press. 16 (1987): 20-21.

"In the C.P.S.U. Central Committee." Izvestiia. 29 May 1987. p. 1; Current Digest of the Soviet Press. 23 (1987): pp. 10-11.

Information Please Almanac. Boston: Houghton Mifflin Company, 1993.

"An Interview with the Chaimen of Latvia's Two Environmental Protection Agencies." Eco Logic. (Quarterly publication of the Environmental protection Club of Latvia Elpa.) January 1992.

Itkin, V. and L. Chernenko. "Lessons of Chernobyl: Reactor Safety." Sovetskaia Rossiia. 26 April 1987: 2; Current Digest of the Soviet Press. 17 (1987): 5+.

Ivanovna, T. and N. Glovatskaia. "Kriterii i printsipy formirovaniia ekologicheskoi politiki." [Criteria and Principles for Forming an Ecological Policy.l Voprosy ekonomiki. 11 (1990): 77-85.

Jancar, Barbara. Environmental Management in the Soviet Union and Yugoslavia: Structure and Regulation in Federal Communist States. Durham: Duke University Press, 1987 .

Karpov, Valerii. Personal interview. 24 November 1991. St. Petersburg, Russia.

Kochurov, Boris Ivanovich. "Na puti $k$ sozdaniiu ekologicheskoi karti SSSR. " [On the Path to Creating an Ecological Map of the U.S.S.R.] Priroda. 8 (August 1989): $10-17$.

Kolbasov, Oleg S. "Environmental Policy and Law in the U.S.S.R." Environmental Law Reporter. 3 (1987): 10681070 .

Koldobsky, V. "The Land Is Not Just the Grain Growers" Concern." Ekonomicheskaia gazeta. 37 (1979): 19; Current Digest of the Soviet Press. 37 (1979): 15-16. 
Komarov, Boris. Unichtozhenie prirody: obostrenie ekologicheskogo krizisa $v$ SSSR. [Destruction of Nature: Intensification of the Ecological Crisis in the U.S.S.R.] Frankfurt: Possev-Verlag, V. Gorachek K. G., 1978 .

KONSOFIN (Jaakko Pöyry Oy and Giprobum, Leningrad). "Environmental Situation and Project Identification in Leningrad and Leningrad Region." Helsinki: 1990.

Korhonen, Jorma. "Juomavettä Viemäristä." [Drinking Water from the Sewer.] Helsingin Sanomat, 27 september 1992: C9. Summarized in English for the author.

Kozhevnikov, Petr. Personal interview. 1 July 1992, st. Petersburg, Russia.

Kraiukhin, Sergei. "Leningrad Atomic Power Station: Inspection by and Help from International Atomic Energy Agency Are Needed." Izvestiia. 26 March 1992: 2; Current Digest of the Soviet Press. 12 (1992): 32 .

Kramer, John M. "Environmental Problems." The Soviet Union Today. Ed. James Cracraft. Chicago: University of Chicago Press, distributor, 1983.

Kuraiev, S. "Please Tell Me About This 'Shield Against Floods." " Pravda. 21 May 1984: 7; Current Digest of the Soviet Press. 20 (1984): 23.

Lavrov, S. B. "Regional and Environmental Problems of the U.S.S.R.: A Synopsis of Views From the Soviet Pariliament." Soviet Geography. September 1990: 47799.

Lemeshev, M. "Ekonomika i ekologiia: rokovoi konflikt i puti ego razresheniia." [Economics and Ecology: the Fatal Conflict and ways to Resolve It.] Voprosy ekonomiki. $11(1990)$ : 68-76.

Lenin, Vladimir Ilich. Sobranie sochinenii. [Collected Works.] Vol. 31. Ed. Julius Katzer. Moscow: Progress Publishers, 1966.

Leningradskii nauchnyi tsentr AN SSSR (et al). (Leningrad Science Center of the U.S.S.R. Academy of Sciences, et al.] "Kontseptsiia razvitiia prirodopol zovaniia v Leningradskom regione." [Conception of Nature-use Development in the Leningrad Regicas.; (Preliminary report.) Leningrad: 1991.

Leonov, Leonid. "Concerning Large Chips of wood." Literaturnaia gazeta. 30 March 1965: 2; Current Digest of the Soviet Press. 20 (1965): 13-15. 
Likhachev, D., D. Granin, M. Dudin, and A. Liverouskii. "A gde zashchita ot damby?" [But Where Is Protection From the Dam?] Izvestiia. 11 January 1987: 3.

Likhachev, D. et al. "Damba stroitsia vopreki trebovaniiam Leningradtsev." [Dike Being Built Contrary to Demands of Leningraders.] Izvestiia. 1 June 1991: 3.

Luchin, I. and V. Vinogradov. "Eshche raz o paraich rtuti." [Once Again about Mercury Vapors.] Vechernii Peterburg, 6 February 1992: 2.

Marples, David. "The Post-Soviet Nuclear Power Program." Presentation at conference "Environmental Security After Communism," and subsequent interview. Ottawa, Ontario. 26 February 1993.

Marx, Karl. Capital: A Critical Analysis of Capitalist Production. Ed. Frederich Engels. Trans. Samuel Moore and Edward Aveling. New York: Humboldt Publishing Co.: 1890 .

Medvedev, Zhores A. Soviet Agriculture. New York, London: w. W. Norton and Company, 1987.

Mikhailov, Konstantin. "Who Can Demonstrate? It.'s a Local Matter." Sobesednik. 3 (1988): 7; Current Digest of the Soviet Press. 10 (1988): 15-16.

Ministry of the Environment of Finland. "Environmental Priority Action Programme for Leningrad, Leningrad Region, Karelia and Estonia: Synthesis Report." September 1991.

Mote, Victor L. "The Geography of Air Pollution in the Soviet Union." Environmental Misuse in the Soviet Union. Ed. Fred Singleton. New York: Praeger Publishers, 1976.

Mote, Victor L. "A Summary of the Glasgow Conference on Soviet Environmental Policies and Practices." Soviet Geography. June 1988: 625-32.

Murry, Don. "C.B.C. National." Television broadcast. 15 September 1992.

Nauchno-issledovatel'skii geografo-ekonomicheskii institut. [Geographical-Economics Kesearch Institute.] At las Leningradskoi Oblasti. [Atlas of the Leningrad Ob]ast.] Moscow: 1967. 
Nevelskii, Vladimir. "stroitel'stvo damby prcstanovit.." [Dike Construction to be Halted.] Izvestiia. 17 detober 1990 : 2 .

Nevelskii, V. and K. Smirnov. "Leningradskaia damba: chas pik." [The Leningrad Dike: The Moment of Truth.] Izvestiia. 28 June $1990: 2$.

Nove, Alec. Soviet Agriculture: The Brezhnev Legacy and Gorbachev's Cure. Rand/U.C.L.A. Center for the study of Soviet International Behavior, 1988.

Nove, Alec. The Soviet Economic System. Third Edition. Boston: Allen and Unwin. Inc., 1986.

"O provedenii rybora konkursa proektov i programm po ozdorovleniiu ekologicheskoi obstanovki $v$ Nevskoi gube $i$ korrektirovke proekta stroitel'stva sooruzhenii zashchity g. Sankt-Peterburga ot navodnenii." IOn the Holding of a Competition for Projects and Programs for Irproving the Ecological Situation in Nevskii Bay and for Correcting the Construction Project to Protect St. petersburg from Floods.] Resolution of the Government of the Russian Federation. 18 May 1992.

Ol'gina, N. "Govoriat, shpiony vodu otravili." [They Say That Spies Poisoned the water.l Vechernii Peterburg. 23 November 1991: 1.

Oxford English Dictionary. Second Edition. Oxford, England: Clarendon Press, 1989.

Peterson, D. J. "The State of the Enviconment: The Air." Report on the U.S.S.R. 2 March 1990: 5-9.

Peterson, D. J. "The State of the Environment: The Land." Report on the U.S.S.R. I June 1990: 8-12.

Peterson, D. J. "The State of the Environment: An Overview." Report on the U.S.S.R. 23 February 1990: 13-17.

Pomagaev, Sergei. Personal interviews. 27 May and 6 June 1992, St. Petersburg, Russia.

Precoda, Norman. "Leningrad's Protective Barrier Against Flooding Project." Soviet Geography. October 1988: $725-735$.

"Priroda i niy: v Prokurature Soiuza SSR." [Nature and Us: In the U.S.S.R. Prosecutor's office.] Izvestiia. 26 November 1987: 6 . 
Proskurin, Petr. Literaturnaia gazeta. 22 July 1986: 10: Current Digest of the Soviet Press. 32 (1986): 9-10.

Pryde, Philip R. Environmental Management in the Soviet Union. Cambridge, England; New York; and Melbourne: Cambridge University Press, 1991.

Pryde, Philip R. "The Future Environmental Agenda of the U.S.S.R." Soviet Geography. June 1988: 555-67.

Rasputin, Valentin. "We Have Only One Baikal." Izvestiia. 17 February 1986: 3,6; Current Digest of the Soviet Press. $7(1986): 5-7+$.

Razin, S. "In the Murky Mirror of Lake Ladoga." Komsomolskaia pravda. 29 May 1987: 2; Current Digest of the Soviet Press. $23(1987): 11+$.

Raznoshchik, v. and v. Lobov. "Attack on Solid Waste." Ekonomicheskaia gazeta. 3 (1979): 16; Current Digest of the Soviet Press. 4 (1979): 15.

Rogers, Terry. Comments at conference "Environmental Security After Communism." Ottawa, Ontario. 27 February 1993 .

"Russia's Greens: The Poisoned Giant Wakes Up." The Economist. 4 November 1989: 23-26.

Sachs, Jeffrey. Interview on "C.N.N. Moneyline." Television broadcast. 15 October 1992.

Sagers, Matthew J. "News Notes." Post-Soviet Geography. April 1992: 237-268; Soviet Geography. April 1991: 251-290; Soviet Geography. April 1990: 278-320.

Sakharov, Andreii. Comments at conference "Human Rights and the Future." Berkeley, California. 11 August 1989.

Shchepotkin, V. "Nature Presents a Bill." Izvestiia. 15 September 1987: 2; Current Digest of the Soviet Press. $36(1987): 6+$.

Shalabin, Geral'd. "Soiti s dorogi, vedushchei v nikuda." [Getting off the Path Leading to Nowhere.] Nevskoe vrenia. 8 May 1992: 2.

Shevtsov, A. "Concerning the Building of the Leningrad Dike." Ekonomicheskaia gazeta. 48 (1986): 10; Current Digest of the Soviet Press. 52 (1986): 13 .

"Situation Returns to Normal, But Questions Remain." Izvestiia. 25 March 1992: 2; Current Digest of the Soviet Press. 12 (1992): 32 . 
Smith, Gordon B. Soviet Politics: Continuity and Contradiction. New York: St. Martin's Press, 1988.

"Soviets Choose Coal Slurry Over Mine-Mouth Plants." Coal Age. May 1986: 24.

Stadnitskii, Georgii. Personal interview. 4 July 1992, St. Petersburg, Russia.

Strugach, Ia. "Fault and Misfortune." Leningradskaia pravda. 21 April 1989: 2; Current Digest of the Soviet Press. 19 (1989): 23-24.

Svenson, Leif. "Kärnkraft i Ryssland." [Nuclear Power in Russia.] Summer 1992. And personal correspondence. Il November 1992. Summarized in English for the author.

Taga, Leonore Shever. "Externalities in a Command Society." Environmental Misuse in the Soviet Union. Ed. Fred Sirgleton. New York: Praeger Publishers, 1976.

Tsuetkov, Sergei. "Peterburgu-chistaia voda?" [Clean Water to Petersburg?] Nevskoe vremia. 4 February 1992: 2.

Tsvetkov, Sergei. "Vodokanal'-na chistuiu vodu!" [Vodokanal-to Clean Water!] Nevskoe vremia. 19 February 1992: 2.

Turnbull, Mildred. Soviet Environmental Policies and Practices: The Most Critical Investment. Hants, England and Brookfield, Vermont: Dartmouth Publishing Company, 1991.

Ulitina, E. "Na puti k effektivnoi prirodookhrannoi sisteme." [On the Way to an Effective Nature Protection System.] Voprosy ekonomiki. 11 (1990): 104-107.

"V TsK KPSS i Sovete Ministrov SSSR." [In the C.P.S.U. Central Committee and the U.S.S.R. Council of Ministers.] Pravia. 19 August 1979: 1.

Vartanov, Raphael. "The Russian North and Environmental Security." Presentation at conference "Environmental Security after Communism." Ottawa, Ontario. 26 February 1993.

Volodin, A. "Ch. P. na atomnoi." [Extraordinary Event at Atoric Station.] Vechernii Peterburg. 24 March 1992: 1 .

Weiner, Douglas R. Models of Nature: Ecology, Conservation, and cultural Revolution in Soviet Russia. Bloomington and Indianapolis: Indiana University Press, 1988. 
Zaharchenko, Tatiana. Personal interview. 12 January 1990, San Francisco, CA.

Zaharchenko, Tatiana. "The Environmental Movement and Ecological Law in the Soviet Union: The Process of Transformation." Ecology Law Quarterly. 3 (1990): 455-475.

Zakharko, V. and V. Mikhailov. "A City's Reliable Shield." Izvestiia. 21 August 1979: 3; Current Digest of the Soviet Press. $34(1979)$ : $8+$.

Zasukha, V. K., V. A. Kirpichnikov, V. N. Klimov, A. G. Petrov, Iu. B. Petrov, and V. E. Sabinin. "Vzaimodeistvie spetsialistov, mestnykh organov vlasti i obshchestvennosti pri priniatii pesheniia o stroitel'stve atomnykh energeticheskikh blokov $v$ SanktPeterburgskom regione." [Cooperation of Specialists, Local organs of Power, and the Public in Decision-Making Concerning Atomic Power Plant Construction in the $S t$. Petersburg Region.] Presentation at Nuclear Society's Third Annual Scientific-Technical Conference, "Nuclear Technologies Tomorrow." St. Petersburg, Russia. 16 September 1992.

Zernova, Lina. "Atomnaia energiia est'. Zakona o ee ispol'zovanii net." [We Have Atomic Energy, but No Law on Its Use.] Nevskoe vremia. 1 May 1992: 2.

Ziegler, Charles E. "The Bear's View: Soviet Environmentalism." Technology Review. April 1987: 4451 .

Ziegler, Charles E. Environmental Policy in the U.S.S.R. London: Frances Pinter Publishers, 1987.

Ziegler, Charles E. "Soviet Images of the Environment." British Journal of Political Science. 15 (1985): 365380 . 


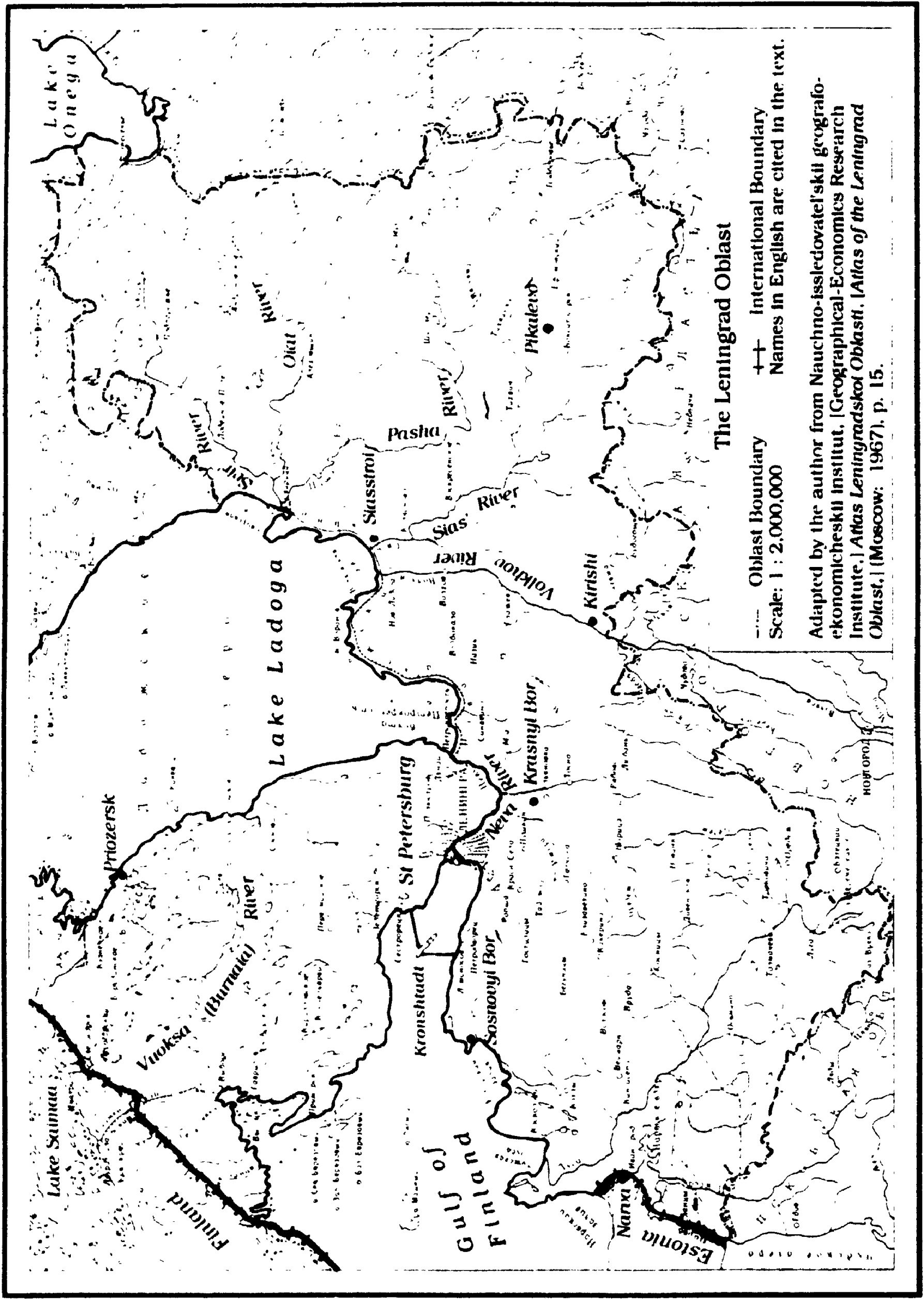




\section{LIST OF INTERVIEWS CONDUCTED}

Aleksandrov, Aleksander. Chair of Environmental Department, U.S.-U.S.S.R. Initiatives. Personal interview. 12 June 1992, St. Petersburg, Russia.

Dobrykh, Iiana. Specialist in rational use of water resources and Assistant to the Chair, SanktPeterborgskii Arkhitekturno-Stroitel'nyi lnstitut. ISt. Petersburg Architecture-Building Institute.] Personal interview. 26 March 1992, St. Petersburg, Russia.

Gushin, vladimir A. Co-Chair of Green Party of St. Petersburg/Leningrad Oblast. Personal interview. 26 June 1992, St. Petersburg, Russia.

Karpov, Valerii. Director of Research, Certer for International Environmental Cooperation (INENCO), U.S.S.R. Academy of Sciences. Personal interview. 24 November 1991, St. Petersburg, Russia.

Kozhevnikov, Petr. Founder and Co-Chair of St. Petersburg environmental group Del'ta. Personal interview. I July 1992, St. Petersburg, Russia.

Marples, David. Canadian Institute of Ukrainian Studies, University of Alberta. Personal interview. 26 February 1993. Ottawa, Ontario.

Pomagaev, Sergei. Member of St. Petersburg City Council and the Council's Ecological Commission. Personal interviews. 27 May and 6 June 1992, St. Petersburg, Russia.

Stadnitskii, Georgii. Member of Petrosoviet and Professor of Biology and Dean of Ecology Faculty. Tekhnologicheskii Institut Tseliuozno-Bumazhnoi Promyshlennosti. [Pulp and Paper Institute of Technology.] Personal interview. 4 July 1992, St. Petersburg, Russia.

Zaharchenko, Tatiana. Environmental Law Professor, Kharkov Law Institute. Personal interview. 12 January 1990, San Francisco, California. 

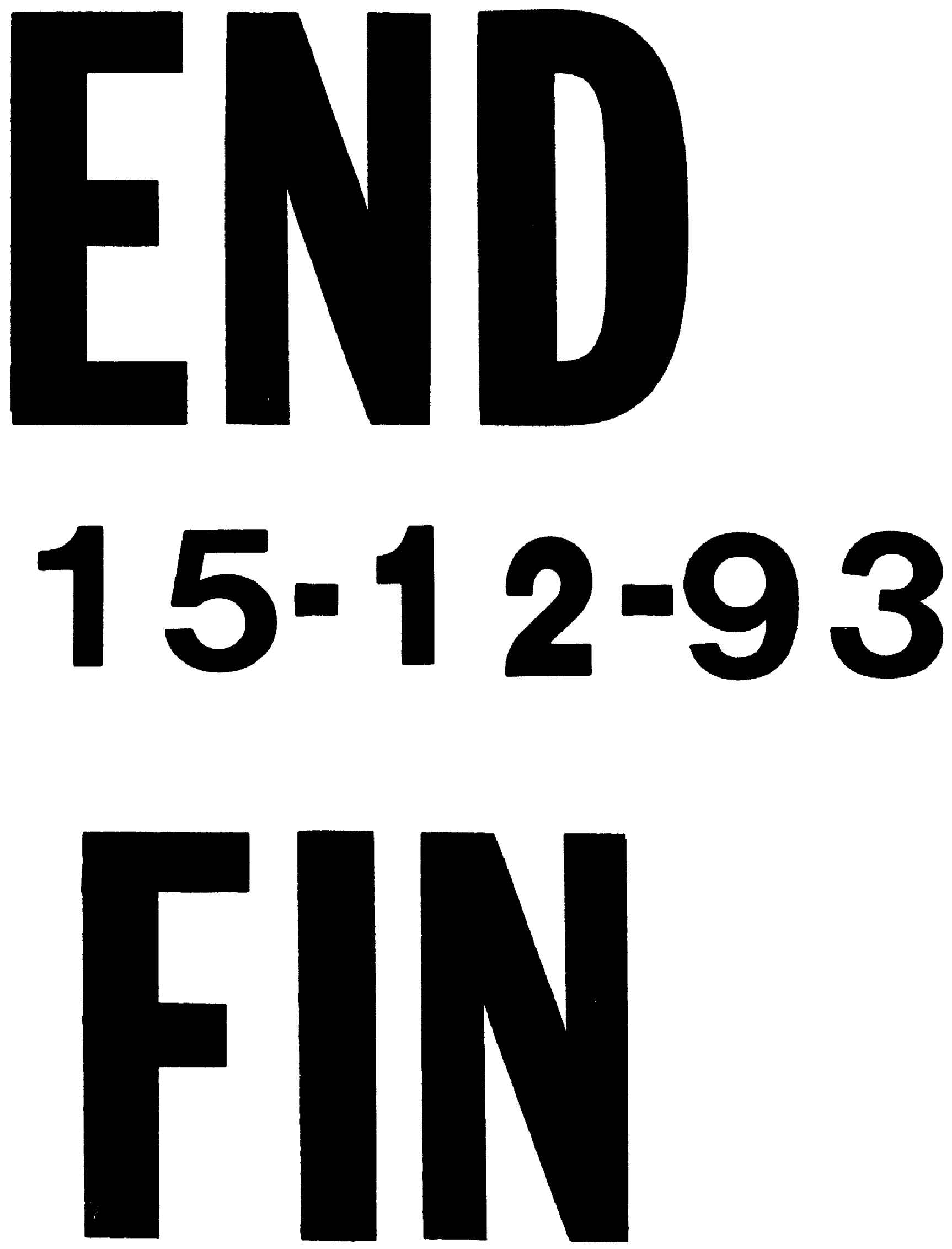